\title{
Regionale arbeidsmarktinformatie naar opleiding en beroep : een verkenning vanuit het ROA- informatiesysteem onderwijs-arbeidsmarkt
}

Citation for published version (APA):

Berendsen, H., de Grip, A., Wieling, M., \& Willems, E. J. T. A. (1992). Regionale arbeidsmarktinformatie naar opleiding en beroep : een verkenning vanuit het $R O A$-informatiesysteem onderwijs-arbeidsmarkt. Researchcentrum voor Onderwijs en Arbeidsmarkt, Faculteit der Economische Wetenschappen. ROA Reports No. 2 https://doi.org/10.26481/umarep.1992002

Document status and date:

Published: 01/01/1992

DOI:

10.26481/umarep.1992002

Document Version:

Publisher's PDF, also known as Version of record

Please check the document version of this publication:

- A submitted manuscript is the version of the article upon submission and before peer-review. There can be important differences between the submitted version and the official published version of record.

People interested in the research are advised to contact the author for the final version of the publication, or visit the DOI to the publisher's website.

- The final author version and the galley proof are versions of the publication after peer review.

- The final published version features the final layout of the paper including the volume, issue and page numbers.

Link to publication

\footnotetext{
General rights rights.

- You may freely distribute the URL identifying the publication in the public portal. please follow below link for the End User Agreement:

www.umlib.nl/taverne-license

Take down policy

If you believe that this document breaches copyright please contact us at:

repository@maastrichtuniversity.nl

providing details and we will investigate your claim.
}

Copyright and moral rights for the publications made accessible in the public portal are retained by the authors and/or other copyright owners and it is a condition of accessing publications that users recognise and abide by the legal requirements associated with these

- Users may download and print one copy of any publication from the public portal for the purpose of private study or research.

- You may not further distribute the material or use it for any profit-making activity or commercial gain

If the publication is distributed under the terms of Article $25 \mathrm{fa}$ of the Dutch Copyright Act, indicated by the "Taverne" license above, 


\section{REGIONALE ARBEIDSMARKTINFORMATIE NAAR OPLEIDING EN BEROEP}

Een verkenning vanuit het ROA-informatiesysteem onderwijs-arbeidsmarkt

ROA-R-1992/2

H. Berendsen
A. de Grip
M.H. Wieling
E.J.T.A. Willems

RESEARCHCENTRUM VOOR ONDERWIJS EN ARBEIDSMARKT

Rijksuniversiteit Limburg

Faculteit der Economische Wetenschappen

Maastricht, maart 1992 
CIP-GEGEVENS KONINKLIJKE BIBLIOTHEEK, DEN HAAG

\section{Regionale}

Regionale arbeidsmarktinformatie naar opleiding en beroep: een verkenning vanuit het ROAinformatiessysteem onderwijs-arbeidsmarkt/H. Berendsen ... [et al.]. - Maastricht: Researchcentrum voor Onderwijs en Arbeidsmarkt, Rijksuniversiteit Limburg, Faculteit der Economische Wetenschappen. - (ROA-R-1992/2)

Met lit. opg.

ISBN 90-5321-071-7 geb.

Trefw.: onderwijs en arbeidsmarkt; Nederland. 
VERANTWOORDING

1. INLEIDING

2. ACTUELE DATA EN INDICATOREN

2.1. Inleiding 5

2.2. Actuele data 5

2.3. Indicatoren 16

2.4. Samenvatting en conclusies $\quad 19$

3. PROGNOSES 21

3.1. Inleiding 21

3.2. Uitbreidingsvraag 23

3.3. Vervangingsvraag 30

3.4. Baanopeningen 34

3.5. Instroom van schoolverlaters 37

3.6. Typering toekomstige arbeidsmarktsituatie $\quad 43$

$\begin{array}{ll}\text { 3.7. Samenvatting en conclusies } & 45\end{array}$

$\begin{array}{lr}\text { 4. BESLUIT } & 47\end{array}$

$\begin{array}{ll}\text { LITERATUUR } & 50\end{array}$

BIJLAGE A: ACTUELE DATA EN INDICATOREN PER RBA-GEBIED 52

BIJLAGE B: $\quad$ MOGELIJK TE PRESENTEREN BEROEPSKLASSEN PER PROVINCIE $\quad 64$

BIJLAGE C: MOGELIJK TE PRESENTEREN OPLEIDINGSTYPEN PER PROVINCIE 72 



\section{VERANTWOORDING}

In opdracht van het Ministerie van Onderwijs en Wetenschappen heeft het Researchcentrum voor Onderwijs en Arbeidsmarkt (ROA) de afgelopen jaren het informatiesysteem onderwijsarbeidsmarkt ontwikkeld. In dit rapport wordt nagegaan in hoeverre de verschillende elementen van dit tot op heden landelijke ROA-informatiesysteem ook op regionaal niveau zouden kunnen worden gepresenteerd. Deze regionale invalshoek heeft daarbij betrekking op een uitsplitsing naar provincie, al zal ook worden aangegeven in hoeverre de arbeidsmarktinformatie eveneens zou kunnen worden verstrekt op het regionale niveau dat overeenkomt met de gebiedsindeling van de Regionale Besturen voor de Arbeidsvoorziening (RBA's). Het onderzoek is behalve door het Ministerie van Onderwijs en Wetenschappen gefinancierd door het Centraal Bestuur voor de Arbeidsvoorziening (CBA) en het Landelijk Dienstverlenend Centrum voor studie- en beroepskeuzevoorlichting (LDC).

Het onderzoek werd uitgevoerd door drs. H. Berendsen, dr. A. de Grip (projectleider), drs. M.H. Wieling en drs. E.J.T.A. Willems. De auteurs danken drs. R.J.P. Dekker en student-assistente M.E.C. Reiners voor hun assistentie bij respectievelijk de verzameling en de verwerking van de vele gegevens. 



\section{INLEIDING}

Het Researchcentrum voor Onderwijs en Arbeidsmarkt (ROA) verschaft sinds 1987 vanuit het ontwikkelde informatiesysteem onderwijs-arbeidsmarkt informatie over de actuele en toekomstige situatie met betrekking tot de aansluiting tussen het onderwijs en de arbeidsmarkt. Sindsdien zijn deze gegevens jaarlijks geactualiseerd en is de informatie geleidelijk uitgebreid. De eind 1991 gereed gekomen versie van dit informatiesysteem bevat gegevens over 93 beroepsklassen en 49 opleidingstypen, verdeeld over de gehele breedte van de arbeidsmarkt.

Deze informatie wordt op twee verschillende manieren naar buiten gebracht. Jaarlijks worden de gegevens geimplementeerd in het Information-System on education and employment (I-See/) ten behoeve van de studie- en beroepskeuzevoorlichting. Dit systeem wordt door het Landelijk Dienstverlenend Centrum voor studie- en beroepskeuzevoorlichting (LDC) uitgebracht op CDROM en bevat naast de bovengenoemde arbeidsmarktinformatie veel feitelijke informatie over circa 1.500 beroepen en 18.000 opleidingen. Daarnaast worden de belangrijkste bevindingen van het informatiesysteem gepubliceerd in de tweejaarlijks uit te brengen rapport De arbeidsmarkt naar opleiding en beroep (zie ROA, 1992) met bijbehorende statistische bijlage.

Het ROA-informatiesysteem bevat voornamelijk landelijke gegevens. Een uitzondering wordt gevormd door een regionale werkloosheidsindicator voor 16 opleidingstypen op lager en middelbaar niveau (zie Wieling, Dekker en De Grip, 1991). Er wordt nogal eens op gewezen dat de aansluitingsproblematiek op de arbeidsmarkt in belangrijke mate een regionaal karakter heeft. Albeda (1991, blz. 9) merkt daarover op: "In principe is de arbeidsmarkt een regionaal fenomeen". Dit maakt de behoefte aan regiospecifieke arbeidsmarktinformatie noodzakelijk (zie ook De Grip, 1991), met name voor het algemeen voortgezet onderwijs, het lager beroepsonderwijs (LBO) en het middelbaar beroepsonderwijs (MBO). Deze behoefte wordt nog versterkt door de nieuwe opzet van de Arbeidsvoorzieningsorganisatie per 1 januari 1991. De verantwoordelijkheid voor het arbeidsvoorzieningsbeleid is sinds die datum neergelegd bij het Centraal Bestuur voor de Arbeidsvoorziening (CBA) en de 28 Regionale Besturen voor de Arbeidsvoorziening (RBA's). De RBA's moeten ieder hun eigen beleid ontwikkelen dat erop is gericht een rechtvaardige en doelmatige aansluiting tussen vraag en aanbod op de arbeidsmarkt te bevorderen.

Regionale arbeidsmarktinformatie is daarnaast van belang voor de studie- en beroepskeuzevoorlichting. Veel mensen zijn immers louter op zoek naar werk op de lokale of regionale arbeidsmarkt (zie ook Albeda, 1991). Dit wordt mogelijk nog versterkt vanwege de toenemende participatie van (gehuwde) vrouwen in het arbeidsproces, waardoor beide partners in hun geografische mobiliteit kunnen worden belemmerd. Scholieren die hun opleidings- of beroepskeuze willen baseren op de actuele of verwachte situatie op de arbeidsmarkt, willen dan met name ook over regionale informatie beschikken.

De Grip (1991) noemt naast het arbeidsvoorzieningsbeleid en de studie- en beroepskeuzevoorlichting nog een tweetal andere zogenaamde directe gebruiksdoelen van regionale 
arbeidsmarktinformatie. Deze bestaan uit de onderwijsplanning van het reguliere onderwijs en het personeelswervings- en personeelsplanningsbeleid van het bedrijfsleven en non-profit organisaties. Daarnaast kan een aantal indirecte gebruiksdoelen worden onderscheiden, zoals het verkeers- en vervoersbeleid, het woningbouwbeleid en het regionale beleid in het algemeen.

Met het oog op de bovengenoemde behoefte aan regiospecifieke arbeidsmarktinformatie kan voor dit rapport de volgende probleemstelling worden geformuleerd:

In hoeverre is het wenselijk en mogelijk het landelijke ROA-informatiesysteem onderwijs-arbeidsmarkt te regionaliseren?

De probleemstelling geeft aan dat het reeds bestaande ROA-informatiesysteem als uitgangspunt is gekozen. Dit houdt automatisch in dat een aantal regionale arbeidsmarktonderzoeken in dit rapport verder buiten beschouwing zal blijven, aangezien deze of op een te hoog aggregatieniveau betrekking hebben of in het geheel geen onderscheid maken naar beroepen en/of opleidingen (zie bijvoorbeeld Nederlands Economisch Instituut, 19851. Andere onderzoeken verkeren op dit moment nog in een experimenteel stadium, zodat ook hierop niet verder wordt ingegaan (zie ook De Grip, 1991). Voorbeelden van dergelijke onderzoeken zijn uitgevoerd door Van der Laan, Scholten en Van der Knaap (1990) en Ooms en Vermeulen (1991).

De bovenstaande vraagstelling kan op een aantal punten verder worden aangescherpt. Allereerst moet worden afgewogen welke elementen van het landelijke informatiesysteem ook op regionaal niveau moeten worden gegenereerd. Daarbij is het van belang te weten dat de gegevens van het informatiesysteem in drie delen kunnen worden opgesplitst:

- actuele data en trends in het recente verleden;

- arbeidsmarktindicatoren;

- middellange-termijn prognoses.

Met behulp van de actuele data wordt informatie verschaft over de (huidige) structuur van de werkgelegenheid en de recente ontwikkelingen daarin. De arbeidsmarktindicatoren kunnen worden gezien als 'risico-factoren' van een bepaalde opleidings- of beroepskeuze. De arbeidsmarktprognoses moeten inzicht verschaffen in de verwachte situatie op de arbeidsmarkt waarmee degenen die momenteel een keuze maken over de te volgen (vervolg)opleiding na het afronden van hun opleiding worden geconfronteerd.

Voor enkele elementen van het informatiesysteem bestaat geen reden om aan te nemen dat het regionale beeld af zal wijken van het landelijke beeld of is het belang van regiospecifieke informatie waarschijnlijk gering. Daarnaast speelt vanzelfsprekend ook de statistische betrouwbaarheid van de te presenteren gegevens een rol. In dit verband kan ook worden opgemerkt dat het Centraal Bureau voor de Statistiek (CBS) aan de statistische gegevens publikatierestricties oplegt in verband met de privacy-gevoeligheid van in verregaande mate verbijzonderde data. 
Behalve de afweging welke elementen van het informatiesysteem worden geregionaliseerd, moet ook worden nagegaan of het wenselijk is de arbeidsmarktinformatie voor alle onderscheiden beroepsklassen en opleidingstypen op regionaal niveau te verzamelen. Het uitgangspunt moet daarbij de daadwerkelijke segmentering van de arbeidsmarkt zijn. Daar veel hoger opgeleiden zich in meerdere regio's aanbieden op de arbeidsmarkt, is er voor deze groep opgeleiden er geen sprake van een regionale arbeidsmarkt. Daarom is het niet zinvol en in feite ook onmogelijk om (betrouwbare) gegevens te presenteren over het hoger beroepsonderwijs $(\mathrm{HBO})^{1}$ en het wetenschappelijk onderwijs (WO). Ook voor het opleidingstype 'MBO Politie \& Defensie' is vrijwel geen sprake van regionaal afgebakende arbeidsmarkten, zodat ook dit opleidingstype hier buiten beschouwing blijft.

Tenslotte moet de probleemstelling worden geconcretiseerd met betrekking tot het geografische niveau waarop het informatiesysteem onderwijs-arbeidsmarkt dient te worden geregionaliseerd. Gezien de bovengenoemde taakstelling van de RBA's lijkt een uitsplitsing naar de 28 RBAgebieden het meest voor de hand te liggen. Daartegenover staat echter dat om betrouwbare arbeidsmarktprognoses op te kunnen stellen de daadwerkelijke segmentering van de arbeidsmarkt als richtlijn moet gelden. Met name het regiogrens-overschrijdende karakter van het aanbod van nieuwkomers op de arbeidsmarkt zal groter zijn naarmate meer regio's worden onderscheiden. Bovendien is het, zoals reeds is aangegeven, van belang te beseffen dat de betrouwbaarheid van de gegevens afneemt naarmate het aggregatieniveau lager wordt. Derhalve wordt vooralsnog voor het prognosegedeelte van het informatiesysteem het provincieniveau als basis voor de regio-indeling gekozen. Voor de actuele data en de arbeidsmarktindicatoren zal de keuze van het regionaal niveau vooral moeten afhangen van de beschikbaarheid en de betrouwbaarheid van de gegevens. Daarbij zal worden nagegaan in hoeverre informatie op provincie- en/of RBA-niveau kan worden gegeven.

Voor het beantwoorden van de bovengenoemde probleemstelling wordt de volgende onderzoeksopzet gehanteerd. In de eerste plaats wordt een aantal actuele data en arbeidsmarktindicatoren van het informatiesysteem geregionaliseerd. De gegevens zijn daarbij afkomstig van de Enquête Beroepsbevolking (EBB) 1988-1990². Op deze manier wordt aangesloten bij de laatste versie van het landelijke informatiesysteem. In de tweede plaats wordt het prognosedeel gedifferentieerd naar provincie. Evenals in het landelijke informatiesysteem wordt voor zowel de beroepsklassen als de opleidingstypen de uitbreidingsen de vervangingsvraag bepaald. De uitbreidingsvraag heeft daarbij betrekking op de vraag naar arbeidskrachten als gevolg van de groei (of krimp) van de werkgelegenheid, terwijl met de vervangingsvraag de vraag naar nieuwkomers als gevolg van pensionering, tijdelijke terugtreding van de arbeidsmarkt en (voor de vervangingsvraag per beroepsklasse) de beroepklassemobiliteit in beeld wordt gebracht (zie ook ROA, 1992). De uitbreidingsvraag en de vervangingsvraag

1. Mogelijk is er voor enkele opleidingstypen in het HBO (bijvoorbeeld het hoger technisch onderwijs) wel sprake van enigszins afgebakende regionale arbeidsmarkten.

2. De EBB-opleidingsgegevens zijn pas vanaf 1990 beschikbaar. 
vormen samen de totale vraag naar nieuwkomers ('baanopeningen') op de arbeidsmarkt. Voor de opleidingstypen wordt deze totale vraag vervolgens geconfronteerd met het totale aanbod van nieuwkomers, waardoor een indicator voor de toekomstige arbeidsmarktsituatie per provincie ontstaat.

Met de gekozen onderzoeksaanpak wordt getracht een regionaal informatiesysteem onderwijsarbeidsmarkt te ontwerpen, waarbinnen de regionale arbeidsmarktinformatie consistent is met de landelijke gegevens. Mogelijke knelpunten die daarbij (kunnen) optreden zullen op deze wijze zichtbaar worden, waardoor een antwoord op de bovengenoemde probleemstelling kan worden geformuleerd.

De verdere opzet van dit rapport is als volgt. In hoofdstuk 2 komen de actuele data en de arbeidsmarktindicatoren aan de orde. In dit hoofdstuk wordt ook een beeld gegeven van het aantal beroepsklassen en opleidingstypen, waarvoor op basis van de beschikbare CBS-gegevens regionale arbeidsmarktinformatie kan worden gegenereerd. Hoofdstuk 3 gaat vervolgens in op de arbeidsmarktprognoses per beroepsklasse en opleidingstype voor de periode 1989-1994. Het rapport wordt in hoofdstuk 4 kort samengevat. Tevens worden in dit hoofdstuk enkele conclusies getrokken ten aanzien van de gehanteerde onderzoeksmethodieken en wordt vanzelfsprekend een antwoord gegeven op de hierboven geformuleerde probleemstelling. Daarbij wordt niet alleen ingegaan op de vraag in hoeverre het ROA-informatiesysteem kan worden geregionaliseerd, maar komt tevens het regionale niveau waarop de arbeidsmarktinformatie zou kunnen worden verstrekt aan de orde. 


\section{ACTUELE DATA EN INDICATOREN}

\subsection{Inleiding}

In hoofdstuk 1 is reeds aangegeven dat een belangrijk deel van de arbeidsmarktinformatie van het ROA-informatiesysteem onderwijs-arbeidsmarkt bestaat uit actuele gegevens over de structuur van de werkgelegenheid. Daarnaast wordt met behulp van een beperkt aantal arbeidsmarktindicatoren getracht inzicht te geven in de arbeidsmarktflexibiliteit en de conjunctuurgevoeligheid van de onderscheiden beroepsklassen en opleidingstypen.

In dit hoofdstuk wordt een overzicht gegeven van de actuele data en indicatoren, die op regionaal niveau zouden kunnen worden gepresenteerd. Daarnaast wordt ingegaan op het aantal beroepsklassen en opleidingstypen waarvoor op regionaal niveau arbeidsmarktinformatie zou kunnen worden weergegeven. Daarbij zal in eerste instantie de arbeidsmarktinformatie worden gepresenteerd op provincieniveau. Telkens zal echter worden aangegeven of de desbetreffende arbeidsmarktinformatie ook op RBA-niveau zou kunnen worden gegenereerd.

De opzet van dit hoofdstuk is als volgt. Eerst wordt in paragraaf 2.2 . ingegaan op de actuele data. In deze paragraaf zal ook een beeld worden geschetst van het aantal op regionaal niveau te presenteren beroepsklassen en opleidingstypen. De arbeidsmarktindicatoren komen daarna aan de orde in paragraaf 2.3. Paragraaf 2.4. vat dit hoofdstuk tenslotte kort samen. Tevens worden in deze paragraaf enkele conclusies getrokken. Daarbij wordt met name ingegaan op het belang van de verschillende elementen van het informatiesysteem en het regionale niveau waarop de in dit hoofdstuk gepresenteerde arbeidsmarktinformatie zou kunnen worden opgeleverd.

\subsection{Actuele data}

Alvorens in te gaan op de actuele data op regionaal niveau, wordt eerst een overzicht gegeven van de gegevens die in het landelijke informatiesysteem op dit punt worden verstrekt. Daarbij kan een onderscheid worden gemaakt tussen beroepsklasse- en opleidingstypegegevens. Het overzicht wordt gepresenteerd in tabel 2.1.

Zoals in hoofdstuk 1 reeds is aangegeven, is het data-technisch niet mogelijk en waarschijnlijk ook niet zinvol om al deze informatie op regionaal niveau te presenteren. Vooralsnog wordt ervan uitgegaan dat op het niveau van beroepsklassen de volgende gegevens op regionaal niveau van belang kunnen zijn:

- aantal werkenden en percentage van de totale werkgelegenheid;

- belangrijkste opleidingstypen;

- belangrijkste bedrijfssectoren.

De volgende opleidingstypegegevens worden op regionaal niveau gegenereerd:

- aantal werkenden en percentage van de totale werkgelegenheid;

- belangrijkste beroepsklassen; 
- belangrijkste bedrijfssectoren ${ }^{3}$;

- werkloosheidspercentage.

In het vervolg van deze paragraaf wordt kort op deze elementen ingegaan. Daaraan voorafgaand wordt echter ingegaan op een tweetal data, die niet beroeps- of opleidingsspecifiek zijn. Eerst komt de regionale sectorstructuur aan de orde en vervolgens wordt per regio bekeken wat de leeftijdsstructuur van de totale werkzame bevolking is.

Tabel 2.1. Overzicht van de actuele data in het landelijke informatiesysteem onderwijs-arbeidsmarkt

\section{Beroeps(klasse)/gegevens}

- aantal werkenden

percentage van de totale werkgelegenheid

aantal werkenden in de ondertiggende beroepsgroepen

- percentage vrouwen per beroepsgroep

percentage deeltijders per beroepsgroep

aandeel leeftijdsgroepen

aandeel opleidingscategorieern

belangrijkste opleidingstypen

- belangrijkste bedrijfssectoren

- percentage zelfstandigen

\section{Opleidingstypegegevens}

- aantal werkenden

percentage van de totale werkgelegenheid

belangrijkste beroepsklassen

belangrijkste beroepsgroepen

werkloosheidspercentage

werkloosheid onder schoolverlaters

De momenteel beschikbare gegevens hebben in het algemeen betrekking op een gemiddelde over de periode 1988-1990. Daarbij wordt ook telkens de trendmatige ontwikkeling in deze periode aangegeven. De RBA-gegevens zijn echter pas vanaf 1989 beschikbaar, zodat hiervoor het tweejaarlijkse gemiddelde van 1989-1990 en de trendmatige ontwikkeling in deze periode wordt weergegeven. Zoals reeds eerder is opgemerkt bevat de EBB pas sinds 1990 betrouwbare opleidingsgegevens op redelijk gedesaggregeerd niveau. De opleidingsgegevens hebben derhalve slechts betrekking op dit laatstgenoemde jaar. Als gevolg hiervan kan bij deze gegevens geen beeld worden geschetst van de trendmatige ontwikkelingen in het recente verleden.

\section{Seciorstructuur}

De mogelijke regionale verschillen in de arbeidsmarktsituatie kunnen in eerste instantie samenhangen met de verschillen in de bedrijfssectorstructuur tussen de diverse regio's. Het is

3. Deze variabele maakt momenteel nog geen deel uit van het landelijke informatiesysteem, maar wordt wel beschouwd als een mogelijke uitbreiding ervan. 
derhalve zinvol gegevens over de sectorstructuur in de verschillende regio's in een regionaal informatiesysteem onderwijs-arbeidsmarkt op te nemen. Om een beeld te geven van de informatie die zou kunnen worden verstrekt, zijn vier bedrijfssectoren geselecteerd waarvoor in tabel 2.2. per provincie het aantal werkenden en het percentage in de totale werkgelegenheid wordt weergegeven ${ }^{4}$. Deze vier sectoren zijn verdeeld over de vier hoofdsectoren (agrarische sector, industrie, commerciële dienstverlening en niet-commerciële dienstverlening):

- Landbouw, visserij en bosbouw;

- Metaalindustrie;

- Handel;

- Openbaar bestuur, defensie en politie.

In een apart rapport zal voor één (voorbeeld)provincie een totaalbeeld worden gegeven van alle momenteel beschikbare arbeidsmarktinformatie. Daarbij is gekozen voor de provincie NoordHolland (zie Berendsen, De Grip, Wieling en Willems, 1992a) ${ }^{6}$.

Uit tabel 2.2. blijkt dat er inderdaad enige verschillen in de provinciale sectorstructuur kunnen worden waargenomen. Deze verschillen zijn het meest duidelijk zichtbaar bij de sector 'Landbouw, visserij en bosbouw'. In de provincies Friesland, Drenthe, Zeeland en vooral Flevoland zijn relatief veel mensen in deze sector werkzaam en in de provincies Utrecht en Noord-Holland relatief weinig. De sector 'Metaalindustrie' blijkt vooral in de provincies Overijssel en Limburg goed vertegenwoordigd te zijn. De provincie Flevoland kent veel werkenden in de sectoren 'Handel' en 'Openbaar bestuur, politie en defensie'. Dit zal samenhangen met de verhoudingsgewijs geringe werkgelegenheid in de industriesector in deze provincie. Bovendien moet worden bedacht dat er onder de werkzame bevolking van de provincie Flevoland een groot aantal forenzen naar de provincie Noord-Holland zijn. Zoals was te verwachten, zijn in de provincie Zuid-Holland relatief veel mensen werkzaam in de sector "Openbaar bestuur, politie en defensie'.

In de tabel wordt het aantal werkenden in de 'Metaalindustrie' voor de provincie Flevoland als 'onbekend' betiteld. Dit hangt samen met de door het CBS gehanteerde publikatierestricties ten aanzien van de EBB-data, waardoor gegevens alleen mogen worden gepubliceerd bij een celvulling van tenminste 5.000 werkenden ${ }^{\theta}$. Overigens is recent met het CBS overeengekomen dat in de toekomst in het geval van driejaarsgemiddelden een publikatierestrictie van 2.000

4. In bijlage A worden de tabellen die in dit hoofdstuk op provincieniveau betrekking hebben op RBA-niveau gepresenteerd.

5. Bovendien wordt voor de provincie (en RBA-gebied) Friesland een tabellenoverzicht met de beschikbare arbeidsmarktinformatie opgesteld. Zie Berendsen, De Grip, Wieling en Willems (1992b).

6. Op grond van de momenteel geldende overeenkomst tussen het CBS en het ROA geldt bovendien dat de 'restcategorieën' van de te publiceren gegevens tenminste 3.000 werkenden moeten bevatten. In de praktijk betekent dit bijvoorbeeld dat als het aantal werkenden in eén regio kleiner is dan 3.000 automatisch ook het aantal werkenden in de een na kleinste regio niet mag worden gepubliceerd. 
personen zal gelden.

Tabei 2.2. Gemiddeld aantal werkenden en gemiddeld percentage van de totale werkgelegenheid per bedrijfssector en provincie 1988-1990

\begin{tabular}{|c|c|c|c|c|}
\hline Provincie & $\begin{array}{l}\text { Landbouw, } \\
\text { visserij en } \\
\text { bosbouw }\end{array}$ & $\begin{array}{l}\text { Metaal- } \\
\text { industrie }\end{array}$ & Handel & $\begin{array}{c}\text { Openbaar bestuur, } \\
\text { politie en } \\
\text { defensie }\end{array}$ \\
\hline \multicolumn{5}{|c|}{ gemiddeld aantal } \\
\hline $\begin{array}{l}\text { Groningen } \\
\text { Friesland } \\
\text { Drenthe } \\
\text { Overijssel } \\
\text { Gelderland } \\
\text { Utrecht } \\
\text { Noord-Holland } \\
\text { Zuid-Holland } \\
\text { Zeeland } \\
\text { Noord-Brabant } \\
\text { Limburg } \\
\text { Flevoland }\end{array}$ & $\begin{array}{r}10.000 \\
17.000 \\
13.000 \\
25.000 \\
45.000 \\
13.000 \\
31.000 \\
57.000 \\
10.000 \\
46.000 \\
23.000 \\
9.000\end{array}$ & $\begin{array}{r}13.000 \\
12.000 \\
11.000 \\
27.000 \\
42.000 \\
16.000 \\
46.000 \\
53.000 \\
7.000 \\
60.000 \\
36.000 \\
-\end{array}$ & $\begin{array}{r}28.000 \\
30.000 \\
24.000 \\
56.000 \\
107.000 \\
75.000 \\
164.000 \\
203.000 \\
21.000 \\
134.000 \\
60.000 \\
14.000\end{array}$ & $\begin{array}{r}20.000 \\
19.000 \\
15.000 \\
28.000 \\
63.000 \\
37.000 \\
86.000 \\
138.000 \\
11.000 \\
64.000 \\
35.000 \\
10.000\end{array}$ \\
\hline $\begin{array}{l}\text { Totaal } \\
\text { gemiddeld perc }\end{array}$ & 298.000 & 326.000 & 917.000 & 526.000 \\
\hline $\begin{array}{l}\text { Groningen } \\
\text { Friesland } \\
\text { Drenthe } \\
\text { Overijssel } \\
\text { Gelderland } \\
\text { Utrecht } \\
\text { Noord-Holland } \\
\text { Zuid-Holland } \\
\text { Zeeland } \\
\text { Noord-Brabant } \\
\text { Limburg } \\
\text { Flevoland }\end{array}$ & $\begin{array}{r}5 \\
8 \\
8 \\
6 \\
6 \\
3 \\
3 \\
4 \\
7 \\
5 \\
5 \\
10\end{array}$ & $\begin{array}{l}6 \\
5 \\
6 \\
7 \\
6 \\
4 \\
4 \\
4 \\
5 \\
6 \\
8 \\
-\end{array}$ & $\begin{array}{l}13 \\
13 \\
14 \\
14 \\
14 \\
16 \\
16 \\
15 \\
15 \\
14 \\
13 \\
17\end{array}$ & $\begin{array}{r}9 \\
8 \\
9 \\
7 \\
8 \\
8 \\
8 \\
10 \\
8 \\
7 \\
8 \\
12\end{array}$ \\
\hline $\begin{array}{l}\text { Totaal } \\
-=\text { onbekend }\end{array}$ & 5 & 5 & 15 & 8 \\
\hline
\end{tabular}

Bron: CBS/ROA

\section{Leefijidsstructuur}

De leeftijdsopbouw van de werkenden geeft enerzijds een beeld van de absorptie van nieuwkomers op de arbeidsmarkt en anderzijds een indicatie van de te verwachten uittrede van ouderen. Tabel 2.3. geeft een overzicht van de gemiddelde leeftijdsstructuur van de werkenden per provincie in de periode 1988-1990. Uit deze tabel blijkt dat er slechts weinig provinciale verschillen in de leeftijdsopbouw van de werkenden bestaan. Alleen de provincie Flevoland 
neemt wat dit betreft een opvallende positie in. In deze provincie is het aandeel van ouderen (vanaf 50 jaar) in de totale werkzame bevolking relatief laag. Met name het aandeel van de 3039 -jarigen is in deze provincie relatief hoog.

Tabel 2.3. Leeftijdsopbouw werkzame bevolking per provincie 1988-1990

\begin{tabular}{lcccc}
\hline Provincie & $\begin{array}{c}\text { Tot } 30 \text { jaar } \\
\%\end{array}$ & $\begin{array}{c}30-39 \text { jaar } \\
\%\end{array}$ & $\begin{array}{c}40-49 \text { jaar } \\
\%\end{array}$ & $\begin{array}{c}\text { Vanaf } 50 \text { jaar } \\
\%\end{array}$ \\
\hline Groningen & 36 & 26 & 23 & 15 \\
Friesland & 36 & 28 & 23 & 14 \\
Drenthe & 34 & 27 & 23 & 15 \\
Overijssel & 37 & 26 & 22 & 15 \\
Gelderland & 36 & 26 & 22 & 15 \\
Utrecht & 36 & 27 & 22 & 15 \\
Noord-Holland & 35 & 28 & 22 & 15 \\
Zuid-Holland & 35 & 28 & 22 & 15 \\
Zeeland & 34 & 28 & 22 & 16 \\
Noord-Brabant & 36 & 27 & 23 & 14 \\
Limburg & 34 & 28 & 23 & 10 \\
Flevoland & 36 & 32 & 21 & 15 \\
Totaal & 36 & 27 & 22 & 15 \\
\hline
\end{tabular}

Bron: CBS/ROA

Aantal werkenden en percentage van de totale werkgelegenheid per beroepsklasse

Met behulp van het aantal werkenden wordt aangegeven hoe groot het belang is van een bepaalde beroepsklasse in de totale werkgellegenheid. Bovendien is de variabele belangrijk, aangezien deze de referentie vormt voor het prognosegedeelte van het informatiesysteem. Bij het verbijzonderen van het aantal werkenden per beroepsklasse naar regio, komt men echter reeds snel in aanraking met de eis van het CBS dat gegevens alleen mogen worden gepubliceerd bij een celvulling van minimaal 5.000 personen.

Op basis van het aantal werkenden per beroepsklasse zal eerst in tabel 2.4. worden ingegaan op het aantal beroepsklassen, waarvoor de omvang van de werkgelegenheid per provincie in 1989 en daarmee ook arbeidsmarktinformatie in het algemeen kan worden gepresenteerd ${ }^{7}$. Tevens is in deze tabel aangegeven hoe groot het aandeel van deze beroepsklassen in de totale provinciale werkgelegenheid is (de zogenaamde 'dekkingsgraad').

Het valt op dat voor de kleinere provincies als Flevoland en Zeeland en de drie Noordelijke provincies voor slechts een gering aantal beroepsklassen informatie kan worden verstrekt. Voor de grotere provincies zoals Noord- en Zuid-Holland en Noord-Brabant kan daarentegen wel op

7. Er is hierbij voor het jaar 1989 gekozen, omdat dit basisjaar van de arbeidsmarktprognoses is. 
een gedesaggregeerd niveau over vrijwel de volle breedte van de arbeidsmarkt informatie over de actuele werkgelegenheidssituatie worden gegeven. Voor acht provincies wordt met de beroepsklassen waarvoor cijfers over de werkgelegenheid kunnen worden gepresenteerd een dekkingsgraad van meer dan $50 \%$ bereikt, waardoor voor deze provincies belangrijke extra inzichten boven de landelijke gegevens kunnen worden verkregen. Bijlage B geeft per provincie een overzicht van de beroepsklassen waarvoor arbeidsmarktinformatie kan worden gepresenteerd. Op RBA-niveau kan voor veel van de in totaal 28 RBA-gebieden slechts voor een gering aantal beroepsklassen informatie worden verstrekt. Op dit RBA-niveau wordt voor de RBA Rijnmond het maximale dekkingspercentage van 75 bereikt, verdeeld over 32 beroepsklassen (zie bijlage A). Zoals hierboven reeds is opgemerkt, zal het in de toekomst mogelijk zijn voor meer beroepsklassen actuele gegevens te verstrekken op basis van driejaarsgemiddelden.

Tabel 2.4. Aantal beroepsklassen waarvoor cijfers over de werkgelegenheid kunnen worden gepresenteerd en het aandeel van deze beroepsklassen in de totale werkgelegenheid ('dekkingsgraad') per provincie 1989

$\begin{array}{lcc}\text { Groningen } & 12 & 48 \\ \text { Friesland } & 13 & 54 \\ \text { Drenthe } & 10 & 43 \\ \text { Overijssel } & 26 & 70 \\ \text { Gelderland } & 42 & 83 \\ \text { Utrecht } & 29 & 73 \\ \text { Noord-Holland } & 53 & 88 \\ \text { Zuid-Holland } & 69 & 94 \\ \text { Zeeland } & 7 & 33 \\ \text { Noord-Brabant } & 56 & 89 \\ \text { Limburg } & 31 & 74 \\ \text { Flevoland } & 2 & 12 \\ & & 98 \\ \text { Total } & 88 & 9\end{array}$

\section{Bron: CBS/ROA}

Om een beeld te geven van de aard van de gegevens die in een regionaal informatiesysteem onderwijs-arbeidsmarkt zouden kunnen worden weergegeven, is een vijftal beroepsklassen geselecteerd waarvoor in dit rapport alle beschikbare informatie per provincie wordt gepresenteerd. Dit betreft enkele grotere beroepsklassen op lager of middelbaar niveau, verdeeld over de verschillende sectoren van de arbeidsmarkt, te weten:

- Uitvoerend agrarisch personeel, bosarbeiders (ROA-code 2011):

- Elektriciens, elektro- en telecom(onderhouds)monteurs (ROA-code 3721);

- Boekhoudkundige, belasting-, loket- en bankemployees (ROA-code 6124);

- Winkel-, straat- en marktverkopers, demonstrateurs (ROA-code 6211);

- Portiers, schoonmaak-e.a. lager dienstverlenend personeel (ROA-code 8211). 
Tabel 2.5. Gemiddeld aantal werkenden en gemiddeld percentage van de totale werkgelegenheid per beroepsklasse en provincie 1988-1990

\begin{tabular}{|c|c|c|c|c|c|c|}
\hline \multirow[b]{2}{*}{ Provincie } & \multirow[b]{2}{*}{2011} & \multirow[b]{2}{*}{3721} & \multicolumn{2}{|c|}{ beroepsklassecode } & \multirow[b]{2}{*}{8291} & \multirow[b]{2}{*}{ Totaal } \\
\hline & & & 6124 & 6211 & & \\
\hline \multicolumn{7}{|c|}{ gemiddeld aantal } \\
\hline Groningen & 6.000 & - & 12.000 & 14.000 & 10.000 & 212.000 \\
\hline Friesland & 9.000 & - & 14.000 & 15.000 & 10.000 & 226.000 \\
\hline Drenthe & 7.000 & - & 9.000 & 12.000 & 7.000 & 171.000 \\
\hline Overijssel & 12.000 & 7.000 & 20.000 & 28.000 & 17.000 & 404.000 \\
\hline Gelderland & 24.000 & 11.000 & 41.000 & 46.000 & 32.000 & 760.000 \\
\hline Utrecht & 8.000 & 7.000 & 28.000 & 29.000 & 17.000 & 454.000 \\
\hline Noord-Holland & 20.000 & 17.000 & 72.000 & 69.000 & 41.000 & 1.049 .000 \\
\hline Zuid-Holland & 36.000 & 23.000 & 80.000 & 81.000 & 50.000 & 1.355 .000 \\
\hline Zeeland & - & - & 7.000 & 10.000 & 7.000 & 144.000 \\
\hline Noord-Brabant & 22.000 & 16.000 & 45.000 & 57.000 & 35.000 & 927.000 \\
\hline Limburg & 13.000 & 8.000 & 24.000 & 29.000 & 20.000 & 455.000 \\
\hline Flevoland & - & - & 6.000 & 5.000 & 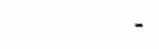 & 86.000 \\
\hline Totaal & 165.000 & 100.000 & 359.000 & 395.000 & 249.000 & 6.244 .000 \\
\hline \multicolumn{7}{|c|}{ gemiddeld percentage } \\
\hline Groningen & 3 & - & 6 & 6 & 5 & 100 \\
\hline Friesland & 4 & - & 6 & 7 & 4 & 100 \\
\hline Drenthe & 4 & - & 5 & 7 & 4 & 100 \\
\hline Overijssel & 3 & 2 & 5 & 7 & 4 & 100 \\
\hline Gelderland & 3 & 1 & 5 & 6 & 4 & 100 \\
\hline Utrecht & 2 & 1 & 6 & 6 & 4 & 100 \\
\hline Noord-Holland & 2 & 2 & 7 & 7 & 4 & 100 \\
\hline Zuid-Holland & 3 & 2 & 6 & 6 & 4 & 100 \\
\hline Zeeland & - & - & 5 & 7 & 5 & 100 \\
\hline Noord-Brabant & 2 & 2 & 5 & 6 & 4 & 100 \\
\hline Limburg & 3 & 2 & 5 & 6 & 4 & 100 \\
\hline Flevoland & - & - & 7 & 6 & - & 100 \\
\hline Totaal & 3 & 2 & 6 & 6 & 4 & 100 \\
\hline - = onbekend & & & & & & \\
\hline
\end{tabular}

2011 Uitvoerend agrarisch personeel, bosarbeiders

3721 Elektriciens, elektro- en telecom(onderhouds)monteurs

6124 Boekhoudkundige, belasting-, loket- en bankemployees

6211 Winkel-, straat- en marktverkopers, demonstrateurs

8211 Portiers, schoonmaak- e.a. lager dienstverlenend personeel

Bron: CBS/ROA

Tabel 2.5. geeft een overzicht van het gemiddeld aantal werkenden en het gemiddeld percentage van de totale werkgelegenheid per provincie in de jaren 1988-1990 voor deze vijf beroepsklassen per provincie. Hieruit blijkt dat er slechts kleine verschillen bestaan in het belang van de onderscheiden beroepsklassen in de diverse provincies. Voor de geselecteerde 
beroepsklassen is de marge van het gemiddeld percentage werkenden van de totale provinciale werkgelegenheid ten opzichte van het landelijke beeld niet groter dan eén procentpunt. Ook op RBA-niveau worden slechts kleine verschillen waargenomen (zie bijlage A).

\section{Belangrijkste opleidingstypen per beroepsklasse}

De relatie tussen beroepen en opleidingen is in het algemeen niet eenduidig. Meerdere opleidingen leiden vaak op tot eenzelfde soort beroep en met een bepaalde opleiding kunnen doorgaans diverse beroepen worden uitgeoefend (zie ook Van Hoof en Dronkers, 1980). Eén van de manieren om na te gaan hoe nauw de relatie beroepsklasse-opleidingstype is, bestaat uit het in beeld brengen van de belangrijkste opleidingsachtergronden van de werkenden per beroepsklasse. Uit een analyse van de beschikbare gegevens ${ }^{B}$ blijkt dat er slechts weinig provinciale verschillen bestaan in de opleidingenstructuur van de beroepsklassen. Bovendien is de gemiddelde celvulling van de datamatrix beroepsklasse naar opleidingstype naar provincie zo gering dat nauwelijks betrouwbare uitspraken ten aanzien van eventuele provinciale verschillen kunnen worden gedaan. De verschillen die tussen de provincies zichtbaar worden hebben namelijk vooral betrekking op het 'wegvallen' van bepaalde categorieēn als gevolg van de publikatierestrictie van minimaal 5.000 werkenden. Vanzelfsprekend is dit op RBA-niveau in nog sterkere mate het geval.

\section{Belangrijkste bedrijfssectoren per beroepsklasse}

Behalve de opleidingsachtergrond van de werkenden kunnen ook de bedrijfssectoren waarin de beroepsbeoefenaren werkzaam zijn per regio verschillend zijn. Derhalve zijn ook per provincie de belangrijkste bedrijfssectoren per beroepsklasse bepaald. Evenais bij de belangrijkste opleidingstypen per beroepsklasse blijken ook hier slechts weinig regionale verschillen op te treden.

\section{Aantal werkenden en percentage van de totale werkgelegenheid per opleidingstype}

Naast het aantal werkenden en het percentage van de totale werkgelegenheid per beroepsklasse is ook het aantal on percentage werkenden per opleidingstype van belang voor een regionaal informatiesysteem onderwijs-arbeidsmarkt. Deze gegevens geven een eerste inzicht in de actuele werkgelegenheidssituatie voor de diverse opleidingscategorieën. Bovendien vormen de gegevens de referentie voor de arbeidsmarktprognoses van het informatiesysteem naar opleidingstype.

Op basis van het aantal werkenden per opleidingstype wordt in tabel 2.6. een overzicht gegeven van het aantal opleidingstypen per provincie, waarvoor de omvang van de

8. Aangezien de twee-dimensionale kruistabellen per provincie erg groot van omvang zijn, worden deze hier niet gepresenteerd. In het reeds eerder genoemde rapport met betrekking tot de provincie Noord-Holland wordt overigens wel hierop ingegaan. 
werkgelegenheid in 1990 kan worden gepubliceerd. Het dekkingspercentage van deze opleidingen wordt hier niet bepaald. Zoals in hoofdstuk 1 reeds is aangegeven, zijn immers de opleidingstypen op HBO- en WO-niveau, alsmede het opleidingstype 'MBO Politie \& Defensie' niet in het regionale informatiesysteem onderwijs-arbeidsmarkt opgenomen, omdat voor deze opleidingen doorgaans geen sprake is van een regionale arbeidsmarkt. Er blijven zodoende 20 opleidingstypen over waarvoor regionale informatie zou kunnen worden verstrekt. In bijlage $C$ is aangegeven voor welke opleidingstypen provinciale arbeidsmarktinformatie beschikbaar is.

Tabel 2.6. Aantal opleidingstypen waarvoor cijfers over de werkgelegenheid kunnen worden gepresenteerd per provincie 1990

\begin{tabular}{lr} 
Groningen & 10 \\
Friesland & 12 \\
Drenthe & 11 \\
Overijssel & 12 \\
Gelderland & 15 \\
Utrecht & 11 \\
Noord-Holiand & 16 \\
Zuid-Holland & 18 \\
Zeeland & 7 \\
Noord-Brabant & 16 \\
Limburg & 12 \\
Flevoland & 5 \\
Totaal & \\
\hline
\end{tabular}

Bron: CBS/ROA

Voor de provincie Zuid-Holland kan voor de meeste opleidingstypen de actuele werkgelegenheid worden gepresenteerd. Slechts de ook landelijk gezien relatief kleine opleidingstypen 'LBO Beveiliging en Bewaking' en 'MBO Technisch Laboratorium' ontbreken in deze provincie. Voor tien van de twaalf provincies kan voor minstens de helft van het aantal onderscheiden opleidingstypen arbeidsmarktinformatie worden gepresenteerd. Voor de provincies Zeeland en Flevoland kan daarentegen slechts voor een gering aantal opleidingstypen arbeidsmarktinformatie worden weergegeven. Naast de acht provincies waarvoor de dekkingsgraad van de te presenteren informatie per beroepsklasse groter is dan 50\%, kan ook voor de provincies Groningen en Drenthe voor 10 of meer opleidingstypen de arbeidsmarkt in kaart worden gebracht. Voor vijf opleidingstypen geldt dat voor iedere provincie gegevens beschikbaar zijn, te weten 'Basisonderwijs', 'MAVO en onderbouw HAVO/NWO', 'LBO Technisch', 'MBO Technisch' en 'MBO Economisch \& Administratief'. Voor de provincie Flevoland zijn dit de enige opleidingstypen waarvoor informatie beschikbaar is. Ook indien het niveau van de RBA-gebieden als regionale indeling wordt gekozen, blijven voor de vijf genoemde opleidingstypen de werkgelegenheidscijfers voor alle onderscheiden regio's beschikbaar. Voor de meeste RBAgebieden geldt dat voor circa 10 van de 20 onderscheiden opleidingstypen informatie kan worden verstrekt (zie bijlage A). 
Als illustratie van de gegevens die in een regionaal informatiesysteem onderwijs-arbeidsmarkt per opleidingstype zouden kunnen worden opgenomen, wordt voor vier opleidingstypen in dit rapport voor alle provincies de beschikbare arbeidsmarktinformatie gepresenteerd. Dit zijn de hierboven genoemde opleidingstypen, met uitzondering van het opleidingstype 'Basisonderwijs'.

Tabel 2.7. Aantal werkenden en percentage van de totale werkgelegenheid per opleidingstype en provincie 1990

\begin{tabular}{|c|c|c|c|c|}
\hline Provincie & $\begin{array}{l}\text { MAVO en } \\
\text { onderbouw } \\
\text { HAVO/VWO }\end{array}$ & $\begin{array}{c}\text { LBO } \\
\text { Technisch }\end{array}$ & $\begin{array}{c}\text { MBO } \\
\text { Technisch }\end{array}$ & $\begin{array}{c}\text { MBO } \\
\text { Economisch \& } \\
\text { Administratief }\end{array}$ \\
\hline \multicolumn{5}{|l|}{ aantal } \\
\hline Groningen & 19.000 & 20.000 & 21.000 & 22.000 \\
\hline Friesland & 17.000 & 23.000 & 28.000 & 22.000 \\
\hline Drenthe & 12.000 & 16.000 & 19.000 & 19.000 \\
\hline Overijssel & 30.000 & 43.000 & 50.000 & 44.000 \\
\hline Gelderland & 60.000 & 76.000 & 89.000 & 93.000 \\
\hline Utrecht & 41.000 & 33.000 & 45.000 & 53.000 \\
\hline Noord-Holland & 91.000 & 70.000 & 104.000 & 120.000 \\
\hline Zuid-Holland & 120.000 & 108.000 & 134.000 & 150.000 \\
\hline Zeeland & 13.000 & 12.000 & 18.000 & 16.000 \\
\hline Noord-Brabant & 76.000 & 96.000 & 113.000 & 99.000 \\
\hline Limburg & 39.000 & 43.000 & 51.000 & 52.000 \\
\hline Flevoland & 9.000 & 8.000 & 8.000 & 11.000 \\
\hline Totaal & 526.000 & 547.000 & 681.000 & 701.000 \\
\hline \multicolumn{5}{|l|}{ percentage } \\
\hline Groningen & 9 & 9 & 10 & 10 \\
\hline Friesland & 7 & 10 & 12 & 10 \\
\hline Drenthe & 7 & 9 & 11 & 11 \\
\hline Overijssel & 7 & 10 & 12 & 11 \\
\hline Gelderland & 8 & 10 & 11 & 12 \\
\hline Utrecht & 9 & 7 & 10 & 11 \\
\hline Noord-Holland & 8 & 7 & 10 & 11 \\
\hline Zuid-Holland & 9 & 8 & 10 & 11 \\
\hline Zeelland & 9 & 8 & 12 & 11 \\
\hline Noord-Brabant & 8 & 10 & 12 & 10 \\
\hline Limburg & 8 & 9 & 11 & 11 \\
\hline Flevoland & 10 & 9 & 9 & 12 \\
\hline Totaal & 8 & 9 & 11 & 11 \\
\hline
\end{tabular}

Bron: CBS/ROA

Tabel 2.7. geeft voor deze opleidingstypen een overzicht van het aantal werkenden en het percentage van de totale provinciale werkgelegenheid in 1990. Het gemiddeld percentage werkenden van de totale werkgelegenheid loopt voor de onderscheiden opleidingstypen enigszins uiteen. Het opleidingstype 'MAVO en onderbouw HAVO/VWO' is vooral sterk vertegenwoordigd in de provincie Flevoland. Bij het opleidingstype 'LBO Technisch' valt op dat 
in de provincies Utrecht en Noord-Holland relatief weinig arbeidskrachten deze opleidingsachtergrond hebben. In de provincie Flevoland is het opleidingstype 'MBO Technisch' relatief slecht vertegenwoordigd. Voor het opleidingstype 'MBO Economisch \& Administratief' is het percentage werkenden van de totale werkgelegenheid tussen de provincies niet veel verschillend. Op RBA-niveau is de variatie in deze cijfers iets groter dan op provincieniveau (zie bijlage Al.

\section{Belangrijkste beroepsklassen per opleidingstype}

Zoals reeds eerder is aangegeven, kunnen met een bepaalde opleiding doorgaans verschillende beroepen worden vitgeoefend. In het landelijke informatiesysteem onderwijs-arbeidsmarkt van het ROA wordt per opleidingscategorie aangegeven wat de belangrijkste beroepsklassen zijn waarin de werkenden actief zijn. Uit een opsplitsing van deze informatie naar provincie blijkt dat hierin, overeenkomstig het beeld bij de eerder genoemde belangrijkste opleidingstypen per beroepsklasse, weinig provinciale verschillen optreden. De verschillen die wel zichtbaar zijn, worden voornamelijk veroorzaakt door de publikatierestricties, waardoor in sommige provincies bepaalde categorieën ontbreken. Dit geldt in versterkte mate indien het RBA-niveau als regioindeling wordt gekozen.

\section{Belangrijkste bedrijfssectoren per opleidingstype}

Aangezien de sectorstructuur van de werkgelegenheid per regio enigszins verschillend is, kunnen ook de (belangrijkste) bedrijfssectoren, waarin de arbeidskrachten met een bepaalde opleiding werkzaam zijn tussen de diverse regio's verschillen. Derhalve is per provincie nagegaan in welke bedrijfssectoren de opgeleiden voornamelijk terecht komen. Evenals bij de belangrijkste beroepsklassen per opleidingstype blijkt dat er op dit punt slechts geringe verschillen tussen de provincies bestaan.

\section{Werkloosheidspercentage per opleidingstype}

Eén van de belangrijkste maatstaven om de huidige situatie op de arbeidsmarkt te typeren is vanzelfsprekend het actuele werkloosheidspercentage. Door Wieling, Dekker en De Grip (1991) is reeds uitgebreid ingegaan op de regionale verschilien in de werkloosheid onder schoolverlaters waarbij de informatie wordt gepresenteerd op RBA-niveau. Hier zal worden ingegaan op de werkloosheid $^{9}$ van de beroepsbevolking per opleidingstype en provincie.

9. Evenals in het landelijke informatiesysteem wordt daarbij het werkloosheidspercentage verkregen door de werkloosheid in april 1991 te relateren aan de som van het aantal werkenden in 1990 en de gemeten werkloosheid in 1991. Er is daarbij gebruik gemaakt van de ISVA-bestanden van de Arbeidsvoorzieningsorganisatie, waarvan algemeen bekend is dat deze gegevens onnauwkeurig zijn, vanwege de bestandsvervuiling en de enigszins tekortschietende codering van de opleidingsgegevens. Voor het onderling vergelijken van werkloosheidscijfers is het ISVA-bestand ons inziens echter een waardevolle informatiebron. 
Tabel 2.8. geeft voor de vier geselecteerde opleidingstypen een overzicht van de provinciale werkloosheid in april 1991. Het blijkt dat voor de provincies Groningen en Friesland de werkloosheid onder deze opleidingscategorieen hoger is dan het landelijke gemiddelde. Verder is het opvallend dat in de provincie Noord-Holland de werkloosheid voor het opleidingstype 'MAVO en onderbouw HAVO/VWO' relatief hoog is. Voor de provincies Utrecht en Zeeland is het werkloosheidspercentage voor de vier opleidingstypen daarentegen relatief laag. Tenslotte kan worden opgemerkt dat de variatie in de werkloosheid op RBA-niveau groter is dan op provincieniveau (zie bijlage A).

Tabel 2.8. Werkloosheidspercentage per opleidingstype en provincie april 1991 (bemiddelingsbestand zonder baan)

\begin{tabular}{lcccc}
\hline Provincie & $\begin{array}{c}\text { MAVO en } \\
\text { Onderbouw } \\
\text { HAVO/VWO }\end{array}$ & $\begin{array}{c}\text { LBO } \\
\text { Technisch }\end{array}$ & $\begin{array}{c}\text { MBO } \\
\text { Technisch }\end{array}$ & $\begin{array}{c}\text { MBO } \\
\text { Economisch \& } \\
\text { Administratief }\end{array}$ \\
\hline Groningen & 20 & 14 & 4 & 4 \\
Friesland & 19 & 14 & 3 & 3 \\
Drenthe & 10 & 6 & 2 & 1 \\
Overijssel & 13 & 7 & 2 & 2 \\
Gelderland & 13 & 6 & 1 & 1 \\
Utrecht & 11 & 10 & 1 & 1 \\
Noord-Holland & 19 & 8 & 2 & 1 \\
Zuid-Holland & 15 & 5 & 1 & 1 \\
Zeeland & 10 & 7 & 1 & 1 \\
Noord-Brabant & 13 & 9 & 1 & 1 \\
Limburg & 15 & 7 & 2 & 2 \\
Flevoland & 14 & 8 & 2 & \\
Total & 15 & & 2 & 1 \\
\hline
\end{tabular}

Bron: Arbeidsvoorzieningsorganisatie/ROA

\subsection{Indicatoren}

Met behulp van een aantal arbeidsmarktindicatoren wordt in het landelijke informatiesysteem onderwijs-arbeidsmarkt getracht het risico van bepaalde beroeps- of opleidingskeuzes aan te geven. Op basis van de conjunctuurindicator kan worden nagegaan in hoeverre de werkgelegenheid aan fluctuaties onderhevig is. Met de Gini-Hirschman flexibiliteitsindicator kan bijvoorbeeld worden aangegeven hoe groot de spreiding van de werkgelegenheid van bepaalde groepen opgeleiden over de verschillende beroepen of bedrijfssectoren is. De indicator geeft daarmee inzicht in de (gerealiseerde) uitwijkmogelijkheden op de arbeidsmarkt van deze opleidingscategorie (zie bijvoorbeeld De Grip en Heijke, 1989). Momenteel zijn de volgende vier arbeidsmarktindicatoren in het landelijke informatiesysteem opgenomen:

- conjunctuurgevoeligheid per beroepsklasse;

- bedrijfssectorspreiding per beroepsklasse;

- beroepenspreiding per opleidingstype; 
- bedrijfssectorspreiding per opleidingstype.

In het algemeen mag worden verwacht dat deze indicatoren per regio slechts weinig zullen verschillen. De regionalisering van deze arbeidsmarktindicatoren is dan weinig zinvol. Een uitzondering kan daarbij worden gemaakt voor de bedrijfssectorspreiding per opleidingstype, vanwege het regiospecifieke karakter van de sectorstructuur van de werkgelegenheid. Daarnaast zou informatie kunnen worden gegeven over de conjunctuurgevoeligheid van de werkgelegenheid in de diverse regio's, waarbij geen onderscheid wordt gemaakt naar beroepsklasse of opleidingstype. Op deze conjunctuurgevoeligheid zal eerst worden ingegaan. Daarna komt de bedrijfssectorspreiding per opleidingstype aan de orde.

\section{Conjunctuurgevoeligheid}

In het landelijke informatiesysteem wordt de conjunctuurgevoeligheid van de werkgelegenheid in de verschillende beroepsklassen getypeerd, door de fluctuatie van de werkgelegenheid in de bedrijfssectoren in het verleden te relateren aan de huidige sectorstructuur per beroepsklasse (zie ook De Grip, Van der Velden en Wieling, 1991 en ROA, 1992). De conjunctuurindicator geeft aan in hoeverre sprake is van een stabiele of instabiele werkgelegenheidssituatie. Bij een hoge conjunctuurgevoeligheid moet rekening worden gehouden met een meer onzekere situatie op de arbeidsmarkt.

Tabel 2.9. Conjunctuurgevoeligheid per provincie

\begin{tabular}{|c|c|c|}
\hline Provincie & Conjunctuurindicator & Typering \\
\hline Groningen & 1,64 & gemiddeld \\
\hline Friesland & 1,67 & gemiddeld \\
\hline Drenthe & 1,68 & gemiddeld \\
\hline Overijssel & 1,77 & relatief hoog \\
\hline Gelderland & 1,70 & gemiddeld \\
\hline Utrecht & 1,60 & relatief laag \\
\hline Noord-Holland & 1,60 & relatief laag \\
\hline Zuid-Hollland & 1,59 & relatief laag \\
\hline Zeeland & 1,70 & gemiddeld \\
\hline Noord-Brabant & 1,84 & relatief hoog \\
\hline Limburg & 1,78 & relatief hoog \\
\hline Flevoland & 1,48 & relatief laag \\
\hline
\end{tabular}

Bron: ROA

Analoog hieraan kan de conjunctuurgevoeligheid van een regio worden bepaald door de sectorale werkgelegenheidsschommelingen in het verleden te combineren met de sector- 
structuur per regio in 1990. In tabel 2.9. wordt de conjunctuurgevoeligheid van de provincies $^{10}$ gepresenteerd. Daarbij is tevens een kwalitatieve typering aan de conjunctuurgevoeligheid gegeven op basis van het gemiddelde en de standaarddeviatie van de gerealiseerde waarden (zie ook Wieling, De Grip en Willems, 1990 ).

Uit tabel 2.9. blijkt dat de conjunctuurgevoeligheid van de werkgelegenheid in de diverse provincies niet sterk uiteenloopt. Wanneer desalniettemin een vergelijking tussen de provincies wordt gemaakt, blijkt dat met name in Overijssel, Noord-Brabant en Limburg de conjunctuurgevoeligheid van de werkgelegenheid relatief groot is. De conjunctuurgevoeligheid is daarentegen relatief klein in de randstandprovincies Noord-en Zuid-Holland en Utrecht en in de provincie Flevaland. Voor de overige provincies is de conjunctuurgevoeligheid ongeveer gelijk aan het landelijke gemiddelde. Ook op RBA-niveau blijken er slechts kleine verschillen in de conjunctuurgevoeligheid te bestaan (zie bijlage A).

\section{Bedrijfssectorspreiding per opleidingstype}

Zoals reeds eerder is aangegeven, kan worden verwacht dat in sommige regio's het flexibiliteitspotentieel naar bedrijfssectoren van bepaalde opleidingscategorieën hoog is, terwijl de spreiding over bedrijfssectoren in andere regio's voor de desbetreffende opleidingscategorie juist laag is, bijvoorbeeld omdat in de laatstgenoemde regio's de mogelijke 'uitwijksectoren' minder goed zijn vertegenwoordigd. In tabel 2.10. wordt op basis van de Gini-Hirschman indicator de provinciale bedrijfssectorspreiding voor de vier geselecteerde opleidingstypen gepresenteerd.

Uit de resultaten van tabel 2.10. kan worden geconcludeerd dat het beeld ten aanzien van de sectorspreiding van de werkgelegenheid voor een bepaald opleidingstype slechts weinig over de provincies varieert, hetgeen in overeenstemming is met de geringe verschillen tussen de provincies in de belangrijkste bedrijfssectoren per opleidingstype (zie paragraaf 2.2.). Daarbij moet well de kanttekening worden gemaakt dat de hier geselecteerde opleidingstypen allemaal relatief breed georiënteerde (c.q. gedefinieerde) opleidingstypen zijn. Ook voor de niet gepresenteerde opleidingstypen geldt echter dat de verschillen tussen de provincies gering zijn. Op RBA-niveau wordt op dit punt eveneens weinig regionale variatie waargenomen (zie bijlage A).

10. De hier gepresenteerde conjunctuurindicator wijkt af van de door het Ministerie van Sociale Zaken en Werkgelegenheid (1991) berekende indicator, als gevolg van het op verschillende wijze bepalen van de conjunctuurgevoeligheid van de werkgelegenheid in de diverse bedrijfssectoren. De resultaten op basis van beide indicatoren komen overigens redelijk overeen. 
Tabel 2.10. Bedrijfssectorspreiding per opleidingstype en provincie 1990 (Gini-Hirschman indicator)

\begin{tabular}{lcccc}
\hline Provincie & $\begin{array}{c}\text { MAVO en } \\
\text { onderbouw } \\
\text { HAVONWO }\end{array}$ & $\begin{array}{c}\text { LBO } \\
\text { Technisch }\end{array}$ & $\begin{array}{c}\text { MBO } \\
\text { Technisch }\end{array}$ & $\begin{array}{c}\text { MBO } \\
\text { Economisch \& } \\
\text { Administratief }\end{array}$ \\
\hline Groningen & 0,94 & 0,95 & 0,94 & 0,92 \\
Friesland & 0,93 & 0,94 & 0,92 & 0,93 \\
Drenthe & 0,90 & 0,94 & 0,95 & 0,89 \\
Overijssel & 0,95 & 0,93 & 0,95 & 0,92 \\
Gelderland & 0,95 & 0,93 & 0,93 & 0,93 \\
Utrecht & 0,91 & 0,94 & 0,94 & 0,90 \\
Noord-Holland & 0,94 & 0,93 & 0,94 & 0,92 \\
Zuid-Holland & 0,93 & 0,95 & 0,95 & 0,93 \\
Zeeland & 0,95 & 0,94 & 0,92 & 0,90 \\
Noord-Brabant & 0,94 & 0,93 & 0,95 & 0,91 \\
Limburg & 0,95 & 0,95 & 0,96 & 0,92 \\
Flevoland & 0,91 & 0,95 & 0,93 & 0,93 \\
Totaal & 0,94 & 0,94 & 0,95 & \\
\hline
\end{tabular}

Bron: ROA

\subsection{Samenvatting en conclusies}

In dit hoofdstuk is een aantal actuele data en arbeidmarktindicatoren, zoals deze voorkomen in het landelijke informatiesysteem onderwijs-arbeidsmarkt van het ROA, geregionaliseerd. Bovendien zijn enkele gegevens verzameld die niet in de hier gepresenteerde vorm in het landelijk informatiesysteem zijn opgenomen.

In de eerste plaats is gekeken naar een tweetal actuele data die niet beroeps- of opleidingsspecifiek zijn, namelijk de sectorstructuur en de leeftijdsstructuur van de werkgelegenheid. De sectorstructuur laat voor de provincies enige kleine verschillen zien. De leeftijdsstructuur van de werkzame bevolking is, met uitzondering van de provincie Flevoland, slechts weinig over de provincies verschillend.

In de tweede plaats zijn de beroepsklasse- en opleidingsgegevens aan de orde gekomen. De belangrijkste data hebben daarbij betrekking op het aantal werkenden per beroepsklasse of opleidingstype en provincie. Voor de grotere provincies, zoals Zuid-Holland en Noord-Brabant kan voor het merendeel van de beroepsklassen en opleidingstypen arbeidsmarktinformatie worden gepresenteerd, rekening houdend met het feit dat er daarvoor tenminste 5.000 werkenden in de desbetreffende provincie moeten zijn ${ }^{11}$. Voor de vier qua werkgelegenheid kleinste provincies, te weten Groningen, Drenthe, Zeeland en Flevoland, kan daarentegen

11. Daarbij kan de kanttekening worden gemaakt dat met het CBS is overeengekomen dat in de toekomst informatie op basis van driejaarsgemiddelden kan worden verstrekt met een ondergrens van 2.000 personen. 
slechts op beperkte schaal arbeidsmarktinformatie worden weergegeven. De beroepsklasseinformatie heeft voor deze provincies slechts betrekking op minder dan helft van de totale werkgelegenheid. Met name voor de provincies Zeeland en Flevoland is het weinig zinvol arbeidsmarktgegevens op een dergelijk gedesaggregeerd niveau van beroepsklassen en opleidingstypen te presenteren.

In de diverse provincies zijn de belangrijkste opleidingstypen of bedrijfssectoren per beroepsklasse weinig verschillend. Ook de data met betrekking tot de belangrijkste beroepsklassen en bedrijfssectoren per opleidingstype vertonen slechts geringe provinciale verschillen. Regionalisering van deze gegevens levert dan ook weinig additionele informatie ten opzichte van de landelijke cijfers. De werkloosheid is daarentegen voor de onderscheiden opleidingstypen per provincie wel verschillend. $O p$ dit punt heeft een regionaal informatiesysteem onderwijs-arbeidsmarkt dus duidelijk een toegevoegde waarde boven de op landelijk niveau te presenteren arbeidsmarktinformatie.

Tenslotte zijn in dit hoofdstuk twee regionale arbeidsmarktindicatoren ontwikkeld. De conjunctuurgevoeligheid blijkt voor de diverse provincies enige kleine verschillen te vertonen. De bedrijfssectorspreiding per opleidingstype is daarentegen slechts weinig over de provincies verschillend.

Een belangrijk aandachtspunt betreft het regionale niveau waarop de actuele data en de arbeidsmarktindicatoren kunnen worden gepresenteerd. Op dit punt kan worden geconcludeerd dat de belangrijkste gegevens, als het aantal werkenden per beroepsklasse en opleidingstype, de werkloosheid per opleidingstype, maar ook de conjunctuurgevoeligheid niet alleen op provinciaal niveau, maar ook op het niveau van de RBA-gebieden kunnen worden weergegeven. Daarbij moet vanzelfsprekend wel worden opgemerkt dat het aantal beroepsklassen en opleidingstypen waarvoor regionale arbeidsmarktinformatie kan worden gepresenteerd beduidend kleiner wordt. Met deze beroepsklassen en opleidingstypen wordt vanzelfsprekend ook een geringer deel van de totale werkgelegenheid bestreken, vergeleken met een regionalisering op provincieniveau.

Samenvattend kan worden geconcludeerd dat het alleen voor enkele 'kerngegevens' van het ROA-informatiesysteem onderwijs-arbeidsmarkt zowel mogelijk als relevant is deze op provinciaal dan wel RBA-niveau te presenteren. Ten eerste is het belangrijk gegevens te verschaffen over de sectorale werkgelegenheidsopbouw in de diverse regio's. Ten tweede levert ook het aantal werkenden en percentage werkenden van de totale werkgelegenheid per beroepsklasse en per opleidingstype belangrijke regionale arbeidsmarktinformatie op. Ten derde kan de werkloosheid per opleidingstype op regionaal niveau worden weergegeven. Tot slot is het zinvol om een indicatie te geven van de conjunctuurgevoeligheid van de werkgelegenheid naar regio. 


\section{PROGNOSES}

\subsection{Inleiding}

Het ROA-informatiesysteem onderwijs-arbeidsmarkt bestaat op landelijk niveau behalve uit actuele data en indicatoren ook uit middellange-termijn prognoses per beroepsklasse en opleidingstype. De meest recente prognoses hebben betrekking op de periode 1989-1994. Daarbij is gekozen voor een 'stroomcijfer' aanpak, die ook op landelijk niveau is gevolgd (zie ROA, 1992). Figuur 3.1. geeft een overzicht van deze (landelijke) stromen op de arbeidsmarkt.

Aan de vraagzijde van de arbeidsmarkt kan een onderscheid worden gemaakt tussen de verwachte uitbreidingsvraag op grond van de toekomstige werkgelegenheidsontwikkeling en de verwachte vervangingswraag als gevolg van pensionering, beroepsmobiliteit e.d. De uitbreidingsen vervangingsvraag vormen samen het verwachte aantal baanopeningen. Aan de aanbodzijde van de arbeidsmarkt kunnen de verwachte instroom van schoolverlaters en het aanbod van (kortdurig) werklozen worden onderscheiden. Door de verwachte vraag- en aanbodstromen met elkaar te confronteren wordt een indicatie verkregen van de toekomstige arbeidsmarktperspectieven per opleidingstype.

In dit hoofdstuk wordt het prognosedeel van het informatiesysteem geregionaliseerd. Daarbij wordt uitgegaan van de hierboven beschreven aanpak. De landelijke prognoseresultaten vormen het kader waarbinnen de regionale prognoses worden opgesteld. Het regionale niveau is, zoals reeds is vermeld in hoofdstuk 1, het niveau van provincies. Uitdrukkellijk moet worden opgemerkt dat de interregionale mobiliteitsstromen, die kunnen optreden als gevolg van eventuele verschillen in de te verwachten discrepanties op de arbeidsmarkt niet in het model zijn opgenomen. De prognoseresultaten geven echter wel een indicatie van de regionale verschillen in de verwachte arbeidsmarktpositie en de mogelijke mobiliteitsprocessen in de toekomst.

Ook ten aanzien van de prognoses kunnen alleen resultaten worden gepresenteerd indien het aantal werkenden in een beroepsklasse of opleidingstype in een regio in het basisjaar van de prognoseperiode tenminste 5.000 bedraagt. Zoals reeds eerder is opgemerkt, wordt in dit rapport geen compleet beeld per provincie weergegeven, maar worden ter illustratie van de prognoseresultaten enkele voorbeeldberoepen en -opleidingen besproken. In dit hoofdstuk wordt daarbij op dezelfde beroepsklassen en opleidingstypen ingegaan als in hoofdstuk 2.

De verdere opzet van dit hoofdstuk is als volgt. Eerst wordt in paragraaf 3.2. de uitbreidingsvraag besproken. Vervolgens komt in paragraaf 3.3. de vervangingsvraag aan de orde. In deze twee paragrafen wordt zowel ingegaan op de gehanteerde methodiek als op de resultaten voor de geselecteerde beroepsklassen en opleidingstypen. Paragraaf 3.4 . gaat in op de verwachte baanopeningen. In paragraaf 3.5. wordt de instroom van schoolverlaters per opleidingstype gepresenteerd, waarbij eveneens op de gehanteerde methodiek en op enkele resultaten wordt ingegaan. De confrontatie van vraag en aanbod vindt plaats in paragraaf 3.6. Het hoofdstuk wordt in paragraaf 3.7 . afgesloten met enkele conclusies. 
Figuur 3.1. Stromen op de arbeidsmarkt

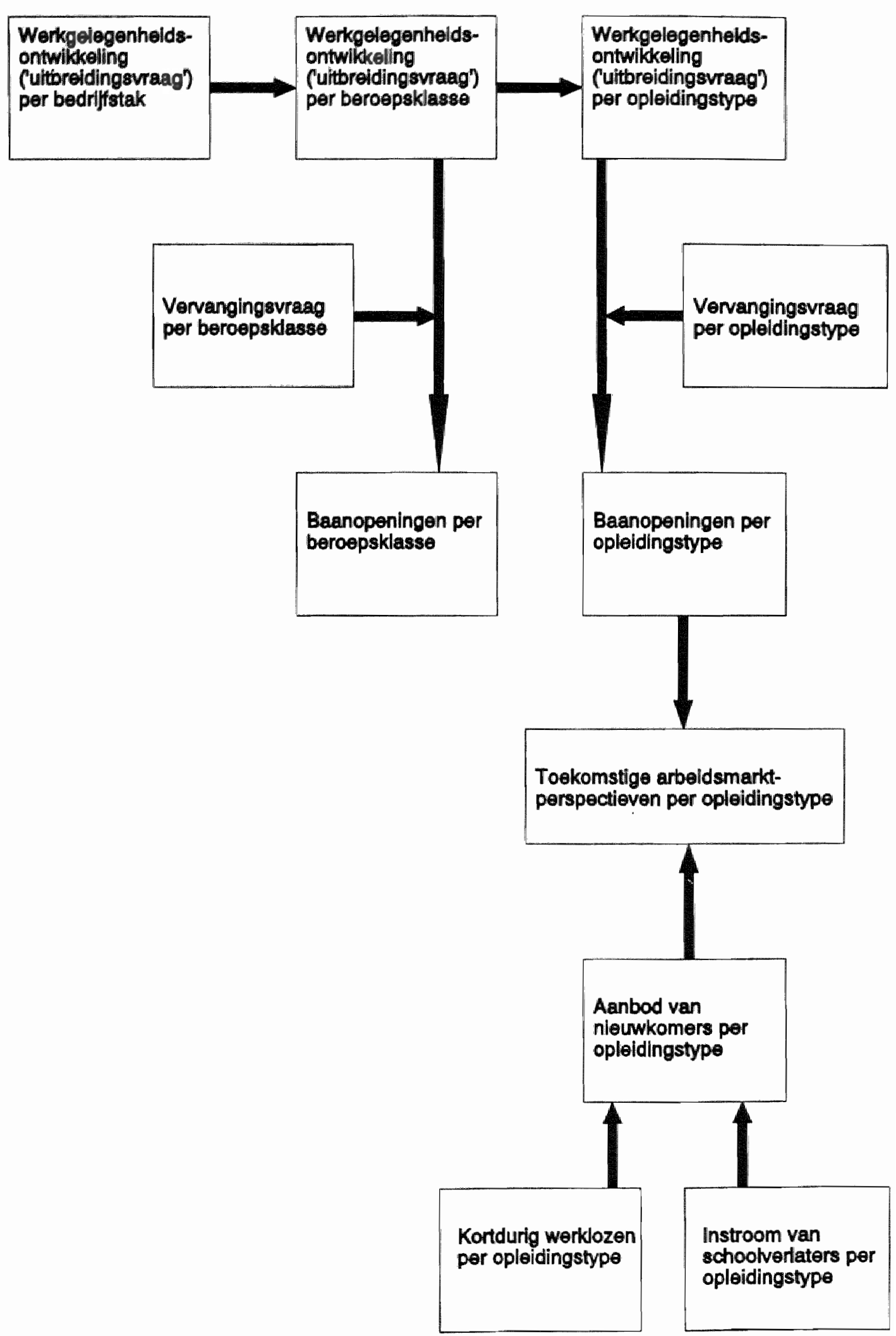




\subsection{Uitbreidingsvraag}

\section{Methodiek}

In deze paragraaf wordt ingegaan op de prognoses van de provinciale werkgelegenheidsontwikkeling per beroepsklasse en per opleidingstype in de periode 1989-1994. In verband met de geringe betrouwbarheid van een analyse op basis van de beschikbare provinciale data is er voor gekozen om geen provinciespecifieke modellen te schatten voor de beroepen- en opleidingenstructuur van de werkgelegenheid. In plaats daarvan worden de verwachte landelijke ontwikkelingen in de beroepen- en opleidingenstructuur van de werkgelegenheid geprojecteerd op de provinciale sectorstructuur van de werkgelegenheid en de verwachte ontwikkeling daarvan. Daarbij wordt gebruik gemaakt van bestaande prognoses van enerzijds de provinciale werkgelegenheid per bedrijfsklasse en anderzijds de landelijke werkgelegenheid per beroepsklasse en per bedrijfsklasse.

In figuur 3.2. is deze aanpak schematisch weergegeven. Daarbij wordt gebruik gemaakt van verschillende kaders. De gegevens die betrekking hebben op de (tussen)resultaten van de landelijke prognoses worden aangegeven door middel van een afgerond kader. De voor het regionale uitbreidingsvraagmodel vereiste additionele data zijn in het schema aangegeven met een zeshoek. De (tussen)resultaten van het regionale model zijn in de figuur aangeduid door middel van een rechthoek. De twee gearceerde rechthoeken geven daarbij de beoogde uiteindelijke prognoseresultaten van de provinciale werkgelegenheidsontwikkeling per beroepsklasse en per opleidingstype weer.

In de bovenste helft van het schema wordt het 'regionale beroepenmodel' gepresenteerd. De eerste stap heeft betrekking op de provinciale werkgelegenheidsontwikkeling per bedrijfsklasse in de periode 1989-1994. De tweede stap geeft de (landelijke) werkgelegenheidsontwikkeling per bedrijfsklasse en per beroepsklasse weer. Door deze beide stappen met elkaar te combineren wordt een voorspelling van de toekomstige provinciale werkgelegenheid per beroepsklasse verkregen ${ }^{12}$. Het onderste gedeelte van het schema geeft het 'regionale opleidingenmodel' weer. Daarbij worden de resultaten van het regionale beroepenmodel gecombineerd met de landelijke ontwikkeling van de opleidingenstructuur binnen de beroepsklassen.

Zoals hierboven is aangegeven, heeft de eerste stap van het regionale beroepenmodel betrekking op de provinciale werkgelegenheid per bedrijfsklasse. Uitgangspunt zijn de prognoses van de provinciale werkgelegenheidsontwikkelingen voor 13 bedrijfstakken, zoals die zijn

12. Deze aanpak verschilt daarmee bijvoorbeeld van de vaste coëfficiënten-methode die in het Canadese COFOR82-model is gehanteerd. Hierin wordt in tegenstelling tot onze studie geen rekening gehouden met de ontwikkeling van de beroepenstructuur binnen bedrijfssectoren. 
Figuur 3.2. Methodiek regionale uitbreidingsuraag

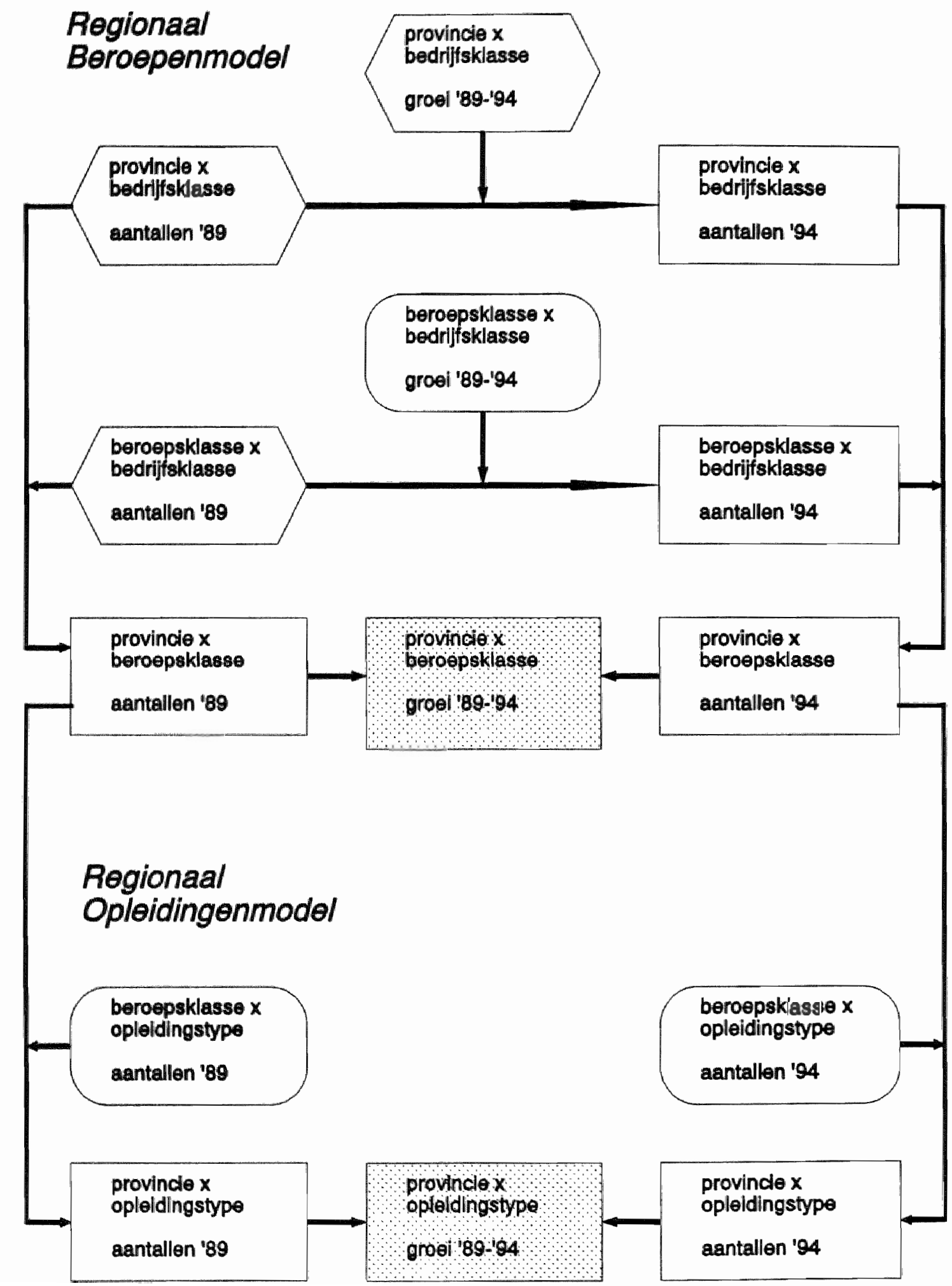


opgesteld door de Arbeidsvoorzieningsorganisatie (Natzijl en Westra, 1991)'. Vervolgens wordt de verwachte provinciale groei van de werkgelegenheid naar bedrijfstak verder verbijzonderd naar 55 bedrijfsklassen, op basis van de veronderstelling dat alle bedrijfsklassen die tot een bedrijfstak behoren dezelfde groei hebben. Op deze wijze wordt de provinciale bedrijfsklassenstructuur in het regionale beroepenmodel meegenomen. Daarbij moet echter worden opgemerkt dat door Natzijl en Westra de werkgelegenheidsontwikkeling is uitgedrukt in arbeidsjaren, terwijl in het regionale uitbreidingsvraagmodel de werkgelegenheidsontwikkeling in werkzame personen wordt uitgedrukt. Aangezien de resultaten van de provinciale werkgelegenheidsontwikkeling per bedrijfsklasse echter worden gerelateerd aan de landelijke werkgelegenheidsontwikkeling per beroepsklasse en per bedrijfsklasse, wordt de verwachte verandering van de verhouding van het arbeidsvolume en het aantal werkzame personen impliciet in deze stap van het regionale beroepenmodel opgenomen ${ }^{14}$. Deze provinciale ontwikkeling in de werkgelegenheid wordt gerelateerd aan het feitelijke aantal werkzame personen in 1989 in de desbetreffende bedrijfsklasse, waardoor een prognose van het verwachte toekomstige aantal werkenden per bedrijfsklasse in een provincie kan worden opgesteld.

Het uitgangspunt voor de tweede stap van het regionale beroepenmodel, met betrekking tot de voorspellingen van de toekomstige landelijke uitbreidingsvraag per beroepsklasse, wordt gevormd door de prognoses van het aantal werkzame personen per bedrijfstak van het Centraal Planbureau (CPB). Op basis van de prognoseresultaten van het landelijke 'ROA-beroepenmodel' wordt de sectorale werkgelegenheidsontwikkeling verbijzonderd naar beroepsklasse. In dit landelijke model wordt de beroepenstructuur binnen bedrijfstakken verklaard uit de technologische ontwikkeling, conjuncturele factoren en eventuele structurele (trend)effecten (zie ook Dekker, De Grip, Berendsen, Wieling en Willems, 1992). Door deze voorspelde toekomstige werkgelegenheidsontwikkeling te combineren met de feitelijke aantallen werkzame personen per bedrijfsklasse en per beroepsklasse in 1989, wordt een prognose verkregen van de toekomstige groei van het aantal werkzame personen per bedrijtsklasse en per beroepsklasse. Daarbij wordt verondersteld dat voor een beroepsklasse de verwachte relatieve ontwikkeling in alle bedrijfsklassen binnen een bepaalde bedrijfstak even groot is.

Vervolgens worden de resultaten van de twee bovengenoemde stappen gecombineerd om tot de provinciale werkgelegenheidsontwikkeling per beroepsklasse te komen. Daartoe wordt voor de jaren 1989 en 1994 het (verwachte) werkgelegenheidsaandeel van de beroepsklassen in de bedrijfsklassen bepaald, waarbij wordt verondersteld dat voor elke provincie de beroepsklassenstructuur binnen bedrijfsklassen hetzelfde is. Aangezien in hoofdstuk 2 slechts weinig regionale

13. De prognoseperiode die in de studie van Natzijl en Westra wordt gehanteerd, komt niet overeen met de in deze studie gehanteerde prognoseperiode. Met behulp van enige door Natzijl en Westra verstrekte additionele data, is de verwachte provinciale werkgelegenheidsontwikkeling per bedrijfstak voor de periode 1989-1994 bepaald.

14. Hierbij wordt verondersteld dat de ontwikkeling van de verhouding van het arbeidsvolume en het aantal werkzame personen per bedrijfstak gelijk is. 
verschillen in de beroepsklassenstructuur binnen bedrijfssectoren is geconstateerd, lijkt dit een plausibele veronderstelling. Op basis van deze aandelen en het aantal werkzame personen per bedrijfsklasse in een provincie, kan voor beide jaren het (verwachte) aantal werkenden per beroepsklasse in een provincie worden bepaald, waarmee prognoses van de verwachte relatieve provinciale groei of krimp in de werkgelegenheid per beroepsklasse voor de periode 1989-1994 worden verkregen. Dit eindresultaat wordt in figuur 3.2. weergegeven door de bovenste gearceerde rechthoek. De verwachte absolute provinciale werkgelegenheidsontwikkeling per beroepsklasse kan vervolgens worden verkregen door de verwachte relatieve ontwikkeling te projecteren op de feitelijke data van het aantal werkenden per beroepsklasse en provincie.

Voor de prognose van de toekomstige provinciale uitbreidingsvraag per opleidingstype wordt gebruik gemaakt van bovengenoemde resultaten uit het regionale beroepenmodel. Daarnaast wordt gebruik gemaakt van de landelijke ROA-prognoses met betrekking tot het verwachte aantal werkenden per beroepsklasse en per opleidingstype voor de jaren $1989^{16}$ en 1994. De verwachte uitbreidingsvraag per beroepsklasse en per opleidingstype voor de periode 19891994 wordt daarbij bepaald met behulp van het 'ROA-opleidingenmodel'. Op basis van economische factoren en eventuele trendeffecten analyseert dit model de ontwikkeling van de opleidingenstructuur binnen beroepen. De technologische ontwikkelingen, die een verklaringsgrond vormen voor het optreden van een toename of afname van het opleidingsniveau dat voor de uitoefening van een bepaald beroep wordt vereist, worden impliciet in het model opgenomen. De vraag naar een opleiding wordt echter eveneens beïnvloed door de relatieve schaarste van arbeidskrachten met de desbetreffende opleidingsachtergrond. Al dan niet via een aanpassing van het loon kan het aanbod van een bepaalde opleiding van invloed zijn op de vraag naar de desbetreffende opleiding (zie verder Dekker, De Grip, Berendsen, Wieling en Willems, 1992).

Om tot de verwachte toekomstige provinciale werkgelegenheidsontwikkeling per opleidingstype te komen, worden in het regionale opleidingenmodel de resultaten van het regionale beroepenmodel gecombineerd met de resultaten van het landelijke opleidingenmodel. Daartoe wordt voor de jaren 1989 en 1994 op basis van bovengenoemd prognosemodel op landelijk niveau, het aandeel van de opleidingstypen in de werkgelegenheid per beroepsklasse bepaald. onder de veronderstelling dat de opleidingstypenstructuur van de werkgelegenheid per beroepsklasse in de verschillende provincies niet afwijkt van het landelijke beeld. Deze veronderstelling mag plausibel worden genoemd, aangezien in hoofdstuk 2 slechts geringe regionale opleidingenstructuurverschillen binnen de onderscheiden beroepsklassen zijn waargenomen. Met behulp van deze opleidingsaandelen in de werkgelegenheid per beroepsklasse en de prognose van het aantal werkenden per beroepsklasse in een provincie, kunnen prognoses van de verwachte relatieve provinciale groei of krimp in de werkgelegenheid per opleidingstype voor de periode 1989-1994 worden verkregen. Dit eindresultaat per

15. Aangezien, zoals reeds eerder is opgemerkt, voor 1989 geen feitelijke opleidingsgegevens beschikbaar zijn, wordt or voor dit jaar uitgegaan van de impliciete prognose van de opleidingenstructuur van de werkgelegenheid binnen beroepsklassen. 
opleidingstype wordt weergegeven door de onderste gearceerde rechthoek. Overigens kan voor de berekening van de absolute werkgelegenheidsgroei per opleidingstype de verwachte relatieve ontwikkeling worden geprojecteerd op de feitelijke gegevens van het aantal werkenden per opleidingstype in de verschillende provincies.

\section{Prognoseresultaten uitbreidingsvraag per beroepsklasse}

In tabel 3.1. worden de resultaten gepresenteerd van het regionale beroepenmodel voor de vijf geselecteerde beroepen. Daarbij staat in de bovenste helft van de tabel weergegeven hoe groot de verwachte toekomstige uitbreidingsvraag in absolute aantallen is. In de onderste helft van de tabel wordt de uitbreidingsvraag uitgedrukt als percentage van het aantal werkenden in 1989. Indien het aantal werkenden in een beroepsklasse in een provincie minder dan 5.000 bedraagt, worden geen werkgelegenheidsprognoses gepresenteerd.

De werkgelegenheid in Nederland neemt in de periode 1989-1994 naar verwachting toe met ruim 400.000 personen, hetgeen overeenkomt met $7 \%$ van het totaal aantal werkenden in 1989. In deze periode zal naar verwachting in alle provincies een toename in de werkgelegenheid optreden ${ }^{18}$. Daarbij valt op dat de relatieve toename in de werkgelegenheid voor Utrecht en Flevoland naar verwachting groter is dan de landelijke uitbreidingsvraag. De provincies Groningen en Zuid-Holland blijven enigszins achter bij de verwachte landelijke werkgelegenheidsgroei.

Overeenkomstig de verwachte landelijke werkgelegenheidsontwikkeling voor de beroepsklasse 'Uitvoerend agrarisch personeel, bosarbeiders' neemt de werkgelegenheid in deze beroepsklasse in de periode 1989-1994 in alle afzonderlijke provincies naar verwachting af. Daarbij is met name de daling in de werkgelegenheid voor de provincies Groningen en Overijssel relatief groot. De procentuele werkgelegenheidsdaling is het kleinst in de provincie Zuid-Holland. De beroepsklasse 'Elektriciens, elektro- en telecom(onderhouds/monteurs' wordt met name in de provincie Utrecht door een relatief grote verwachte werkgelegenheidstoename gekenmerkt. Voor de beroepsklasse 'Boekhoudkundige, belasting-, loket- en bankemployees' wordt, vergeleken met de kleine landelijke werkgelegenheidsgroei, in de provincies Groningen, Noord-Holland en ZuidHolland een lichte werkgelegenheidsdaling verwacht.

De grote absolute en relatieve toename in de landelijke werkgelegenheid voor "Winkel-, straaten marktverkopers, demonstrateurs' en 'Portiers, schoonmaak- e.a. lager dienstverlenend personeel' is eveneens terug te vinden in alle afzonderlijke provincies. Met betrekking tot de

16. De relatieve groei in de totale werkgelegenheid per provincie komt niet geheel overeen met de prognose van de totale werkgelegenheidsgroei per provincie van Natzijl en Westra (1991). Dit heeft te maken met het feit dat Natzijl en Westra uitgaan van het arbeidsvolume, terwijl de prognoses hier betrekking hebben op werkzame personen. Bovendien kan een verschil tussen beide prognoses ontstaan doordat de provinciale prognoses per bedrijfsklasse zijn gerelateerd aan de resultaten van het landelijke informatiesysteem. 
beroepsklasse 'Winkel-, straat- en marktverkopers, demonstrateurs' valt op dat de verwachte uitbreidingsvraag voor de provincies Flevoland en Utrecht relatief groot is. De provincie Groningen geeft een relatief lage werkgelegenheidsgroei te zien voor de beroepsklasse 'Portiers, schoonmaak- e.a. lager dienstverlenend personeel', terwijl naar verwachting de uitbreidingsvraag voor deze beroepsklasse in de provincie Utrecht relatief groot is.

Tabel 3.1. Uitbreidingsvraag per beroepsklasse en provincie 1989-1994

\begin{tabular}{|c|c|c|c|c|c|c|}
\hline \multirow[b]{2}{*}{ Provincie } & \multirow[b]{2}{*}{2011} & \multirow[b]{2}{*}{3721} & \multicolumn{2}{|c|}{ beroepsklassecode } & \multirow[b]{2}{*}{8211} & \multirow[b]{2}{*}{ Totaal } \\
\hline & & & 6124 & 6211 & & \\
\hline \multicolumn{7}{|c|}{ absolute aantallen } \\
\hline Groningen & -1.100 & - & -200 & 2.900 & 1.400 & 11.300 \\
\hline Friesland & -1.300 & - & 200 & 3.500 & 2.200 & 14.200 \\
\hline Drenthe & -1.000 & - & 200 & 2.300 & 1.300 & 9.600 \\
\hline Overijssel & -2.100 & 400 & 500 & 6.700 & 3.300 & 27.700 \\
\hline Gelderland & -3.300 & 600 & 600 & 10.000 & 6.300 & 47.700 \\
\hline Utrecht & -1.300 & 700 & 800 & 7.200 & 4.100 & 49.800 \\
\hline Noord-Holland & -2.800 & 800 & -700 & 13.100 & 7.100 & 71.100 \\
\hline Zuid-Holland & -4.100 & 1.000 & -900 & 15.800 & 8.500 & 71.400 \\
\hline Zeeland & & - & 100 & 1.700 & 1.400 & 8.300 \\
\hline Noord-Brabant & -3.500 & 600 & 700 & 12.500 & 6.700 & 56.200 \\
\hline Limburg & -1.800 & 300 & 200 & 6.000 & 4.100 & 28.200 \\
\hline Flevoland & -600 & - & - & 1.500 & - & 9.300 \\
\hline Totaal & -23.500 & 5.100 & 1.800 & 83.100 & 47.200 & 404.500 \\
\hline \multicolumn{7}{|c|}{ als percentage van het aantal werkenden in 1989} \\
\hline Groningen & .18 & - & -1 & 21 & 16 & 5 \\
\hline Friesland & -16 & - & 1 & 23 & 20 & 6 \\
\hline Drenthe & -16 & - & 2 & 23 & 19 & 6 \\
\hline Overijssel & -17 & 6 & 3 & 24 & 21 & 7 \\
\hline Gelderland & -13 & 6 & 2 & 23 & 20 & 6 \\
\hline Utrecht & -14 & 9 & 3 & 26 & 23 & 11 \\
\hline Noord-Holland & -14 & 6 & -1 & 21 & 19 & 7 \\
\hline Zuid-Holland & -11 & 5 & -1 & 20 & 17 & 5 \\
\hline Zeeland & - & - & 1 & 21 & 20 & 6 \\
\hline Noord-Brabant & -15 & 4 & 2 & 23 & 20 & 6 \\
\hline Limburg & -15 & 3 & 1 & 22 & 21 & 6 \\
\hline Flevoland & -12 & - & - & 31 & - & 11 \\
\hline Totaal & -14 & 5 & 1 & 22 & 19 & 7 \\
\hline - = onbekend & & & & & & \\
\hline
\end{tabular}

2011 Uitvoerend agrarisch personeel, bosarbeiders

3721 Elektriciens, elektro- en telecom(onderhouds)monteurs

6124 Boekhoudkundige, belasting-, loket- en bankemployees

6211 Winkel-, straat- en marktverkopers, demonstrateurs

8211 Portiers, schoonmaak- e.a. lager dienstverlenend personeel

Bron: ROA 
In tabel 3.2. worden de prognoseresultaten van de uitbreidingsvraag voor de vier geselecteerde opleidingstypen weergegeven. Ook hier is een onderscheid gemaakt tussen de verandering in de werkgelegenheid in absolute en in relatieve zin. De relatieve werkgelegenheidsontwikkeling wordt daarbij uitgedrukt als percentage van (de impliciete prognose van) het aantal werkenden in 1989. Zoals reeds eerder is aangegeven, zijn echter voor het jaar 1989 geen feitelijke gegevens over de werkzame bevolking naar opleidingstype beschikbaar. Derhalve is de absolute werkgelegenheidsontwikkeling bepaald door de verwachte relatieve ontwikkeling in de periode 1989-1994 te relateren aan de opleidingsgegevens van de werkzame bevolking in 1990 .

Tabel 3.2. Uitbreidingsvraag per opleidingstype en provincie 1989-1994

\begin{tabular}{lcccc}
\hline Provincie & $\begin{array}{c}\text { MAVO en } \\
\text { onderbouw } \\
\text { HAVO/VWO }\end{array}$ & $\begin{array}{c}\text { LBO } \\
\text { Technisch }\end{array}$ & $\begin{array}{c}\text { MBO } \\
\text { Technisch }\end{array}$ & $\begin{array}{c}\text { MBO } \\
\text { Economisch \& } \\
\text { Administratief }\end{array}$ \\
\hline
\end{tabular}

absolute aantallen

$\begin{array}{lrrrr}\text { Groningen } & 300 & -1.100 & 1.600 & 3.400 \\ \text { Friesland } & 600 & -1.300 & 2.200 & 3.900 \\ \text { Drenthe } & 400 & -1.100 & 1.300 & 3.300 \\ \text { Overijssel } & 1.400 & -2.700 & 3.800 & 8.400 \\ \text { Gelderland } & 1.900 & -5.000 & 6.200 & 16.200 \\ \text { Utrecht } & 1.900 & -800 & 4.900 & 10.900 \\ \text { Noord-Holland } & 700 & -4.000 & 7.600 & 19.100 \\ \text { Zuid-Holland } & -200 & -7.600 & 7.900 & 22.200 \\ \text { Zeeland } & 300 & -900 & 1.000 & 2.700 \\ \text { Noord-Brabant } & 2.500 & -7.200 & 6.800 & 17.800 \\ \text { Limburg } & 1.100 & -3.100 & 3.300 & 9.000 \\ \text { Flevoland } & 600 & -200 & 900 & 2.500 \\ & & & & \\ \text { Totaal } & 11.700 & -34.700 & 47.700 & 119.200\end{array}$

als percentage van het aantal werkenden in 1989

$\begin{array}{lrrrr}\text { Groningen } & 2 & -5 & 8 & 16 \\ \text { Friesland } & 4 & -6 & 8 & 18 \\ \text { Drenthe } & 3 & -7 & 7 & 17 \\ \text { Overijssel } & 5 & -6 & 8 & 19 \\ \text { Gelderland } & 3 & -7 & 7 & 17 \\ \text { Utrecht } & 5 & -2 & 11 & 21 \\ \text { Noord-Holland } & 1 & -6 & 7 & 16 \\ \text { Zuid-Holland } & -0 & -7 & 6 & 15 \\ \text { Zeeland } & 2 & -8 & 6 & 17 \\ \text { Noord-Brabant } & 3 & -7 & 6 & 18 \\ \text { Limburg } & 3 & -7 & 7 & 17 \\ \text { Flevoland } & 7 & -2 & 11 & 23 \\ \text { Totaal } & & & & 17\end{array}$

Bron: ROA 
De werkgelegenheid zal naar verwachting voor het opleidingstype 'MAVO en onderbouw HAVONWW' in vrijwel alle provincies toenemen. Het is daarbij opvallend dat voor de provincie Zuid-Holland een kleine werkgelegenheidsdaling wordt verwacht. Daarentegen is de uitbreidingsvraag voor dit opleidingstype in de provincie Flevoland naar verwachting relatief groot. Voor het opleidingstype 'LBO Technisch' is de verwachte landelijke afname in de werkgelegenheid in de periode 1989-1994 terug te zien in alle provincies. Daarbij wordt voor de provincies Utrecht en Flevoland een kleinere daling van de werkgelegenheid verwacht. De twee geselecteerde opleidingstypen op MBO-niveau vertonen een gunstige ontwikkeling in de werkgelegenheid, hetgeen zich in alle provincies weerspiegelt. Daarbij is de procentuele werkgelegenheidstoename zowel voor 'MBO Economisch \& Administratief' als voor 'MBO Technisch' het grootst in de provincies Utrecht en Flevoland.

\subsection{Vervangingsvraag}

\section{Methodiek}

Naast de verwachte uitbreidingsvraag is ook de toekomstige vervangingsvraag van belang voor de totale vraag naar nieuwkomers op de arbeidsmarkt. Deze vervangingsvraag kan het gevolg zijn van pensionering, vervroegde uittreding (VUT), al dan niet tijdelijke terugtrekking van de arbeidsmarkt van met name gehuwde vrouwen in verband met de verzorging van de kinderen en de beroepsmobiliteit (zie Willems en De Grip, 1990 i.

In het landelijke ROA-informatiesysteem onderwijs-arbeidsmarkt wordt de vervangingsvraag per beroepsklasse bepaald door de in de analyseperiode 1981-1985 waargenomen geslachts- en leeftijdsspecifieke netto verloopcoëfficiënten per beroepsklasse te 'extrapoleren' naar de toekomst. Bij deze projectie wordt een correctie toegepast voor de conjuncturele ontwikkelingen in de analyseperiode. Daarnaast wordt rekening gehouden met de verwachte ontwikkelingen in de participatiegraad.

De landelijke prognose van de vervangingsvraag per opleidingstype wordt op analoge wijze verkregen. Daarbij treedt echter een belangrijk verschil op. De beroepsmobiliteit is namelijk, in tegenstelling tot de vervangingsvraag per beroepsklasse, niet van invloed op de vervangingsvraag per opleidingstype. Daardoor is de gemiddelde vervangingsvraag per opleidingstype lager dan de gemiddelde vervangingsvraag per beroepsklasse.

Met behulp van deze methodiek kan vervolgens ook de toekomstige provinciale vervangingsvraag per beroepsklasse en per opleidingstype worden bepaald. Evenals bij de uitbreidingswraagprognose is er hier voor gekozen niet op provinciaal niveau een specifieke analyse te maken van de historische ontwikkeling. In plaats daarvan wordt een aanpak gehanteerd waarbij de verwachte landelijke verloopcoëfficiënten (per geslacht en leeftijdscategorie) worden geprojecteerd op de geslachts- en leeftijdsopbouw van de provinciale werkgelegenheid. Gezien de vaak geringe celvulling van de gegevens omtrent het aantal werkenden in een provincie per beroepsklasse of opleidingstype en geslacht en leeftijdscategorie, verdient deze methode de 
voorkeur boven het op provinciaal niveau bepalen van de verloopquotes. Bovendien mag worden verwacht dat de verlooppercentages per geslacht en leeftijdscategorie tussen de provincies weinig zullen verschillen. Veel belangrijker zijn immers de eventuele verschillen in de geslachts- en leeftijdsstructuur van de provinciale werkgelegenheid, waarmee wel rekening wordt gehouden. Tevens wordt op deze manier bewerkstelligd dat de som van de vervangingsvraag over de provincies overeenkomt met het landelijke totaal.

\section{Prognoseresultaten vervangingsvraag per beroepsklasse}

De resultaten van de provinciale vervangingsvraag per beroepsklasse in de periode 1989-1994 zijn weergegeven in tabel 3.3. Landelijk gezien bedraagt de gemiddelde vervangingsvraag per beroepsklasse $12 \%$ van het aantal werkenden in $1989^{17}$. Dit komt overeen met ongeveer 715.000 werkenden. De totale procentuele vervangingsvraag is voor de diverse provincies slechts weinig verschillend. Alleen de provincie Flevoland kent een iets lagere vervangingsvraag. Vanzelfsprekend hangt dit samen met de relatief jonge gemiddelde leeftijd van de arbeids. krachten in deze provincie (zie paragraaf 2.2.).

Voor de geselecteerde beroepsklassen is er sprake van een meer gedifferentieerd beeld. De verwachte vervangingsvraag voor de beroepsklasse 'Uitvoerend agrarisch personeel, bosarbeiders' is relatief laag voor de provincies Friesland, Noord-Holland en Limburg. In de provincies Groningen en Overijssel is er daarentegen, vergeleken met de landelijke prognose, sprake van een relatief hoge vervangingsvraag. Voor deze laatstgenoemde provincie is ook de vervangingsvraag naar 'Elektriciens, elektro- en telecom(onderhouds)monteurs' naar verwachting relatief hoog. De verwachte vervangingsvraag is voor deze beroepsklasse in de provincie Utrecht relatief laag.

De provincie Zeeland kent voor de beroepsklasse 'Boekhoudkundige, belasting-, loket"- en bankemployees' naar verwachting een relatief lage vervangingsvraag. Voor de provincie Drenthe wordt voor deze beroepsklasse een vervangingsvraag verwacht die iets hoger is dan de landelijke prognose. De toekomstige vervangingsvraag naar 'Winkel-, straat- on marktverkopers, demonstrateurs' loopt naar verwachting uiteen van $14 \%$ in Drenthe tot $21 \%$ in de provincie Utrecht. Bij de resultaten van de provinciale vervangingsvraag voor 'Portiers, schoonmaak- e.a. lager dienstverlenend personeel' is tenslotte vooral de relatief hoge vervangingsvraag in de provincie Drenthe opvallend. Ook voor de provincie Groningen wordt voor deze beroepsklasse een vervangingsvraag verwacht die iets hoger is dan het landelijke cijfer.

17. Doordat hierbij ook de vervangingsvraag van enkele 'restberoepen' is inbegrepen, is dit percentage iets hoger dan de door ROA (1992) gepresenteerde $11 \%$. 
Tabel 3.3. Vervangingsvraag per beroepsklasse en provincie $1989 \cdot 1994$

\begin{tabular}{|c|c|c|c|c|c|c|}
\hline \multirow[b]{2}{*}{ Provincie } & \multirow[b]{2}{*}{2011} & \multirow[b]{2}{*}{3727} & \multicolumn{2}{|c|}{ beroepsklassecode } & \multirow[b]{2}{*}{8211} & \multirow[b]{2}{*}{ Totaa } \\
\hline & & & 6124 & 6211 & & \\
\hline \multicolumn{7}{|c|}{ absolute aantallen } \\
\hline Groningen & 1.100 & - & 1.300 & 2.500 & 1.200 & 25.200 \\
\hline Friesland & 700 & . & 1.500 & 2.700 & 1.400 & 24.100 \\
\hline Drenthe & 1.000 & - & 1.100 & 1.400 & 1.100 & 20.000 \\
\hline Overijssel & 2.300 & 1.100 & 1.900 & 5.300 & 2.000 & 46.200 \\
\hline Gelderland & 4.100 & 1.100 & 3.700 & 7.600 & 3.600 & 85.200 \\
\hline Utrecht & 1.200 & 600 & 2.600 & 5.800 & 2.000 & 53.900 \\
\hline Noord-Holland & 2.100 & 1.800 & 7.500 & 11.500 & 4.400 & 124.000 \\
\hline Zuid-Holland & 4.900 & 2.800 & 5.800 & 14.100 & 6.700 & 157.400 \\
\hline Zeeland & & - & 500 & 1.500 & 800 & 16.700 \\
\hline Noord-Brabant & 3.200 & 1.800 & 4.000 & 9.900 & 3.900 & 101.300 \\
\hline Limburg & 1.300 & 800 & 2.000 & 5.300 & 2.200 & 54.200 \\
\hline Flevoland & 700 & - & - & 1.000 & - & 8.300 \\
\hline Totaal & 22.900 & 11.600 & 32.100 & 68.600 & 29.600 & 714.600 \\
\hline \multicolumn{7}{|c|}{ als percentage van het aantal werkenden in 1989} \\
\hline Groningen & 18 & - & 10 & 18 & 14 & 12 \\
\hline Friesiand & 9 & - & 10 & 18 & 12 & 11 \\
\hline Drenthe & 16 & - & 11 & 14 & 16 & 12 \\
\hline Overijssel & 19 & 15 & 9 & 19 & 13 & 12 \\
\hline Gelderland & 16 & 11 & 9 & 17 & 11 & 11 \\
\hline Utrecht & 14 & 7 & 10 & 21 & 19 & 12 \\
\hline Noord-Holland & 11 & 13 & 10 & 18 & 12 & 12 \\
\hline Zuid-Holland & 14 & 13 & 8 & 18 & 13 & 12 \\
\hline Zeeland & - & . & 6 & 19 & 12 & 12 \\
\hline Noord-Brabant & 14 & 11 & 9 & 18 & 12 & 11 \\
\hline Limbura & 11 & 11 & 8 & 20 & 11 & 12 \\
\hline Flevoland & 13 & $=$ & - & 19 & - & 10 \\
\hline Totaal & 14 & 12 & 9 & 18 & 12 & 12 \\
\hline = onbekend & & & & & & \\
\hline
\end{tabular}

2011 Uitvoerend agrarisch personeel, bosarbeiders

3721 Elektriciens, elektro- en telecom(onderhouds/monteurs

6124 Boekhoudkundige, belasting-, loket- en bankemployees

6211 Winkel-, straat- en marktverkopers, demonstrateurs

8211 Portiers, schoonmaak- e.a. lager dienstverlenend personeel

Bron: ROA

Prognoseresultaten vervangingsvraag per opleidingstype

Tabel 3.4. geeft een beeld van de verwachte provinciale vervangingsvraag in de periode 1989 1994 voor de vier geselecteerde opleidingstypen. De variatie in de vervangingsvraag tussen de provincies is voor deze vier opleidingstypen erg klein. In de provincie Overijssel is de 
vervangingsvraag voor het opleidingstype 'MAVO en onderbouw HAVO/VWO' relatief laag. vergeleken met het landelijke gemiddelde voor dit opleidingstype. Voor de provincie Zeeland is de verwachte toekomstige vervangingsvraag naar werkenden met deze opleidingsachtergrond daarentegen hoger dan het landelijke gemiddelde. Bij 'LBO Technisch' is het met name opvallend dat de vervangingsvraag in Friesland en Zeeland naar verwachting relatief laag is. De verwachte procentuele vervangingsvraag voor 'MBO Technisch' wijkt voor de verschillende provincies slechts weinig af van het landelijke gemiddelde. In de provincie Groningen is or sprake van een relatief hoge vervangingsvraag voor het opleidingstype 'MBO Economisch \& Administratief'. Voor Flevoland wordt voor dit opleidingstype een relatief hoge vervangingsvraag verwacht.

Tabel 3.4. Vervangingsvraag per opleidingstype en provincie 1989-1994

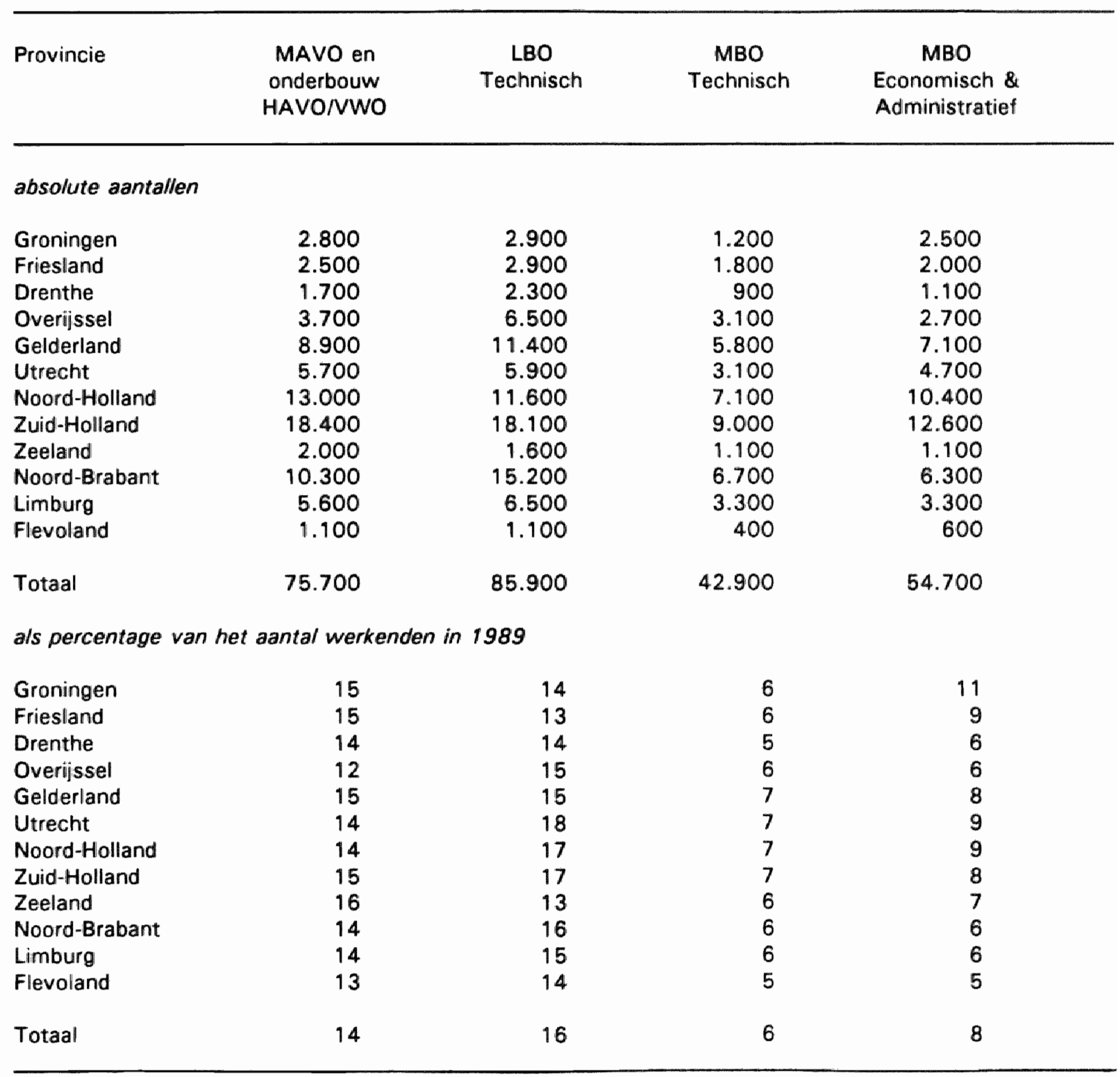

Bron: ROA 



\subsection{Baanopeningen}

Prognoseresultaten baanopeningen per beroepsklasse

Door de provinciale prognoses voor de werkgelegenheidstoename te combineren met de provinciale vervangingsvraagsprognoses wordt de verwachte totale vraag naar nieuwkomers (het aantal 'baanopeningen') op de arbeidsmarkt verkregen. In tabel 3.5. worden de toekomstige baanopeningen voor de vijf geselecteerde beroepsklassen in de verschillende provincies gepresenteerd.

Het totaal aantal baanopeningen in Nederland bedraagt in de periode 1989-1994 naar verwachting ruim 1,1 miljoen. Dit komt overeen met $18 \%$ van het totaal aantal werkenden in 1989. Daarbij valt op dat procentueel gezien de meeste baanopeningen in de desbetreffende periode voor de provincies Utrecht en Flevoland worden verwacht, hetgeen wordt veroorzaakt door de, ten opzichte van het landelijke totaal, relatief hoge uitbreidingsvraag voor beide provincies. In de overige provincies komt de verwachte totale vraag naar nieuwkomers ongeveer overeen met het totale percentage baanopeningen in Nederland.

Voor de beroepsklasse 'Uitvoerend agrarisch personeel, bosarbeiders' bestaat de totale vraag naar nieuwkomers in alle provincies uitsluitend uit de toekomstige vervangingsvraag. Dit betekent dat het provinciale beeld voor de totale vraag naar nieuwkomers overeenstemt met de provinciale vervangingsvraag. Met betrekking tot de beroepsklasse 'Elektriciens, elektro- en telecom(onderhouds)monteurs' kan worden opgemerkt dat de verwachte toekomstige totale vraag relatief groot is in de provincie Overijssel. Dit heeft te maken met de relatief hoge vervangingsvraag voor deze beroepsklasse in de desbetreffende provincie. in Noord-Brabant en Limburg is daarentegen sprake van een relatief lage verwachte totale vraag. Verhoudingsgewijs de meeste baanopeningen voor de beroepsklasse 'Boekhoudkundige, belasting-, loket- en bankemployees' worden verwacht voor de provincies Drenthe en Utrecht. Dit wordt voornamelijk veroorzaakt door een relatief hoge vervangingsvraag, terwijl voor de provincie Utrecht er bovendien sprake is van een relatief grote werkgelegenheidsgroei. In de provincie Zeeland blijft de totale vraag naar nieuwkomers in de periode 1989-1994 naar verwachting enigszins achter bij de landelijke vraag naar nieuwkomers. Dit hangt samen met een relatief lage vervangingsvraagprognose.

In tegenstelling tot de bovengenoemde beroepsklassen bestaat de totale vraag naar nieuwkomers in de overige twee geselecteerde beroepsklassen voor een belangrijk deel uit de verwachte werkgelegenheidstoename. Overeenkomstig de relatief gezien lage vervangingsvraag vertoont de provincie Drenthe verhoudingsgewijs de minste verwachte baanopeningen voor de beroepsklasse 'Winkel-, straat- en marktverkopers, demonstrateurs'. Voor de desbetreffende beroepsklasse is de totale vraag naar nieuwkomers in de provincies Utrecht en Flevoland groter dan de landelijke vraag, hetgeen te maken heeft met de reeds eerder genoemde relatief grote werkgelegenheidsgroei in deze provincies. Ten opzichte van de landelijke totale vraag naar nieuwkomers wordt de beroepsklasse 'Portiers, schoonmaak- e.a. lager dienstverlenend 
personeel' gekenmerkt door een groot aantal baanopeningen in de provincie Drenthe. Dit wordt veroorzaakt door de relatief hoge vervangingsvraag voor deze beroepsklasse in de desbetreffende provincie.

Tabel 3.5. Baanopeningen per beroepsklasse en provincie 1989-1994

\begin{tabular}{|c|c|c|c|c|c|c|}
\hline \multirow[b]{2}{*}{ Provincie } & \multirow[b]{2}{*}{2011} & \multirow[b]{2}{*}{3721} & \multicolumn{2}{|c|}{ beroepsklassecode } & \multirow[b]{2}{*}{8211} & \multirow[b]{2}{*}{ Totaal } \\
\hline & & & 6124 & 6211 & & \\
\hline \multicolumn{7}{|c|}{ absolute aantallen } \\
\hline Groningen & 1.100 & - & 1.300 & 5.400 & 2.700 & 36.500 \\
\hline Friesland & 700 & - & 1.700 & 6.200 & 3.500 & 38.300 \\
\hline Drenthe & 1.000 & - & 1.300 & 3.700 & 2.400 & 29.600 \\
\hline Overijssel & 2.300 & 1.500 & 2.400 & 12.000 & 5.400 & 73.900 \\
\hline Gelderland & 4.100 & 1.700 & 4.400 & 17.600 & 9.900 & 132.800 \\
\hline Utrecht & 1.200 & 1.300 & 3.400 & 13.000 & 6.100 & 103.700 \\
\hline Noord-Holland & 2.100 & 2.600 & 7.500 & 24.700 & 11.400 & 195.100 \\
\hline Zuid-Holland & 4.900 & 3.800 & 5.800 & 29.900 & 15.200 & 228.800 \\
\hline Zeeland & - & - & 600 & 3.300 & 2.200 & 25.000 \\
\hline Noord-Brabant & 3.200 & 2.400 & 4.700 & 22.400 & 10.600 & 157.500 \\
\hline Limburg & 1.300 & 1.100 & 2.100 & 11.300 & 6.300 & 82.400 \\
\hline Flevoland & 700 & - & - & 2.500 & - & 17.600 \\
\hline Totaal & 22.900 & 16.700 & 33.900 & 151.700 & 76.800 & 1.119 .100 \\
\hline \multicolumn{7}{|c|}{ als percentage van het aantal werkenden in 1989} \\
\hline Groningen & 18 & $=$ & 10 & 38 & 30 & 17 \\
\hline Friesland & 9 & - & 12 & 41 & 32 & 17 \\
\hline Drenthe & 16 & - & 13 & 37 & 35 & 17 \\
\hline Overijssel & 19 & 22 & 11 & 43 & 34 & 19 \\
\hline Gelderland & 16 & 17 & 11 & 40 & 31 & 18 \\
\hline Utrecht & 14 & 16 & 13 & 46 & 34 & 23 \\
\hline Noord-Holland & 11 & 19 & 10 & 39 & 31 & 19 \\
\hline Zuid-Holland & 14 & 17 & 8 & 38 & 30 & 17 \\
\hline Zeeland & - & - & 7 & 41 & 32 & 17 \\
\hline Noord-Brabant & 14 & 15 & 10 & 41 & 32 & 17 \\
\hline Limburg & 11 & 14 & 9 & 42 & 31 & 18 \\
\hline Flevoland & 13 & - & - & 50 & - & 20 \\
\hline Totaal & 14 & 17 & 10 & 40 & 32 & 18 \\
\hline
\end{tabular}

2011 Uitvoerend agrarisch personeel, bosarbeiders

3721 Elektriciens, elektro- en telecom(onderhouds)monteurs

6124 Boekhoudkundige, belasting-, loket- en bankemployees

6211 Winkel-, straat- en marktverkopers, demonstrateurs

8211 Portiers, schoonmaak- e.a. lager dienstverlenend personeel

Bron: ROA 
Prognoseresultaten baanopeningen per opleidingstype

Tabel 3.6. Baanopeningen per opleidingstype en provincie 1989-1994

\begin{tabular}{|c|c|c|c|c|}
\hline Provincie & $\begin{array}{c}\text { MAVO en } \\
\text { onderbouw } \\
\text { HAVONWO }\end{array}$ & $\begin{array}{c}\text { LBO } \\
\text { Technisch }\end{array}$ & $\begin{array}{c}\text { MBO } \\
\text { Technisch }\end{array}$ & $\begin{array}{c}\text { MBO } \\
\text { Economisch \& } \\
\text { Administratief }\end{array}$ \\
\hline \multicolumn{5}{|c|}{ absolute aantallen } \\
\hline $\begin{array}{l}\text { Groningen } \\
\text { Friesland } \\
\text { Drenthe } \\
\text { Overijssel } \\
\text { Gelderland } \\
\text { Utrecht } \\
\text { Noord-Holland } \\
\text { Zuid-Holland } \\
\text { Zeeland } \\
\text { Noord-Brabant } \\
\text { Limburg } \\
\text { Flevoland }\end{array}$ & $\begin{array}{r}3.100 \\
3.100 \\
2.100 \\
5.000 \\
10.800 \\
7.700 \\
13.700 \\
18.400 \\
2.300 \\
12.800 \\
6.800 \\
1.800\end{array}$ & $\begin{array}{r}2.900 \\
2.900 \\
2.300 \\
6.500 \\
11.400 \\
5.900 \\
11.600 \\
18.100 \\
1.600 \\
15.200 \\
6.500 \\
1.100\end{array}$ & $\begin{array}{r}2.700 \\
4.000 \\
2.200 \\
6.900 \\
12.000 \\
8.000 \\
14.700 \\
16.900 \\
2.200 \\
13.500 \\
6.600 \\
1.300\end{array}$ & $\begin{array}{r}6.000 \\
5.900 \\
4.400 \\
11.100 \\
23.300 \\
15.600 \\
29.600 \\
34.800 \\
3.800 \\
24.100 \\
12.400 \\
3.100\end{array}$ \\
\hline Totaal & 87.400 & 85.900 & 90.600 & 173.800 \\
\hline \multicolumn{5}{|c|}{ a/s percentage van het aantal werkenden in 1989} \\
\hline $\begin{array}{l}\text { Groningen } \\
\text { Friesland }\end{array}$ & $\begin{array}{l}16 \\
19\end{array}$ & $\begin{array}{l}14 \\
13\end{array}$ & $\begin{array}{l}13 \\
14\end{array}$ & $\begin{array}{l}27 \\
27\end{array}$ \\
\hline Drenthe & 17 & 14 & 11 & 23 \\
\hline Overijssel & 17 & 15 & 14 & 25 \\
\hline Gelderland & 18 & 15 & 14 & 25 \\
\hline Utrecht & 19 & 18 & 18 & 29 \\
\hline Noord-Holland & 15 & 17 & 14 & 25 \\
\hline Zuid-Holland & 15 & 17 & 13 & 23 \\
\hline Zeeland & 18 & 13 & 12 & 24 \\
\hline Noord-Brabant & 17 & 16 & 12 & 24 \\
\hline Limburg & 17 & 15 & 13 & 24 \\
\hline Flevoland & 20 & 14 & 16 & 28 \\
\hline Totaal & 17 & 16 & 13 & 25 \\
\hline
\end{tabular}

Bron: ROA

In het algemeen kan worden opgemerkt dat in alle provincies de vervangingsvraag een grote rol speelt bij de totale vraag naar nieuwkomers voor de opleidingstypen 'MAVO en onderbouw HAVO/VWO' en 'LBO Technisch'. Bij het laatstgenoemde opleidingstype wordt de totale vraag zelfs geheel bepaaid door de vervangingsvraag, vanwege de negatieve werkgelegenheidsontwikkeling in alle provincies. Hetzelfde geldt voor de provincie Zuid-Holland voor het eerstgenoemde opleidingstype. Ten opzichte van het landelijke verwachte aantal baanopeningen voor het opleidingstype 'MAVO en onderbouw HAVO/NWO' wordt de provincie Flevoland gekenmerkt door een relatief grote verwachte vraag naar nieuwkomers. Dit wordt veroorzaakt door de in vergelijking met de landelijke werkgelegenheidsontwikkeling relatief hoge 
uitbreidingsvraag. De baanopeningen voor de opleidingstypen 'MBO Technisch' en 'MBO Economisch \& Administratief' bestaan voornamelijk uit de verwachte werkgelegenheidstoename in de periode 1989-1994. De relatief grote werkgelegenheidsgroei voor de opleidingstypen 'MBO Technisch' en 'MBO Economisch \& Administratief' in de provincies Utrecht en Flevoland is duidelijk terug te vinden in de verwachte totale vraag naar nieuwkomers.

\subsection{Instroom van schoolverlaters}

In deze paragraaf wordt een prognose opgesteld van de provinciale instroom van schoolverlaters op de arbeidsmarkt per opleidingstype in de periode 1989-1994. De basisingrediënten voor deze prognoses worden gevormd door bestaande externe prognoses van de provinciale uitstroom uit het regulier voortgezet voltijdonderwijs en de landelijke uitstroom uit het primair onderwijs (basis- en speciaal onderwijs) en het hoger onderwijs (HBO en WO). De laatstgenoemde prognoses zijn opgenomen in het landelijke informatiesysteem onderwijs-arbeidsmarkt van het ROA, waaraan ook een aantal andere gegevens wordt onttrokken. Daarnaast wordt gebruik gemaakt van regionale cijfers met betrekking tot het Kort Middelbaar Beroepsonderwijs (KMBO) en het Leerlingwezen.

Aan de ramingsmethodiek van de provinciale arbeidsmarktinstroom van schoolverlaters liggen geen verklarende modellen ten grondslag ${ }^{18}$. De methodiek kan in twee stappen worden opgesplitst. In de eerste stap worden prognoses opgesteld van de provinciale uitstroom van leerlingen uit het regulier voltijdonderwijs naar opleidingstype. In de tweede stap vindt een correctie van deze prognoses plaats om rekening te houden met de doorstroom van het regulier voltijdonderwijs naar het niet-regulier voltijdonderwijs en het (regulier en niet-regulier) deeltijdonderwijs en de daarin behaalde opleidingskwalificaties.

In figuur 3.3. is stap 1 van de ramingsmethodiek van de toekomstige provinciale instroom van schoolverlaters op de arbeidsmarkt schematisch weergegeven. Daarbij zijn de gegevens die direct of na herbewerking aan het landelijke informatiesysteem zijn ontleend, gemarkeerd door een afgerond kader. De data die specifiek voor het opstellen van de provinciale instroomprognoses zijn verzameld, worden door een zeshoek aangeduid. De (tussen)resultaten van de provinciale prognoses zijn omlijnd door een rechthoek, waarbij de rechthoek met het eindresultaat van de eerste stap is gearceerd.

Zoals gezegd, wordt bij de provinciale prognoses van de toekomstige arbeidsmarktinstroom van schoolverlaters per opleidingstype uitgegaan van bestaande prognoses. In het kader van het onderzoek Regionalisering Uitstroom Voortgezet Onderwijs (RUVO) is door Vermeulen (1990)

18. Dit geldt eveneens voor de onderliggende externe prognoses. 
Figuur 3.3. Methodiek regionale prognose instroom van schoolverlaters, stap 1

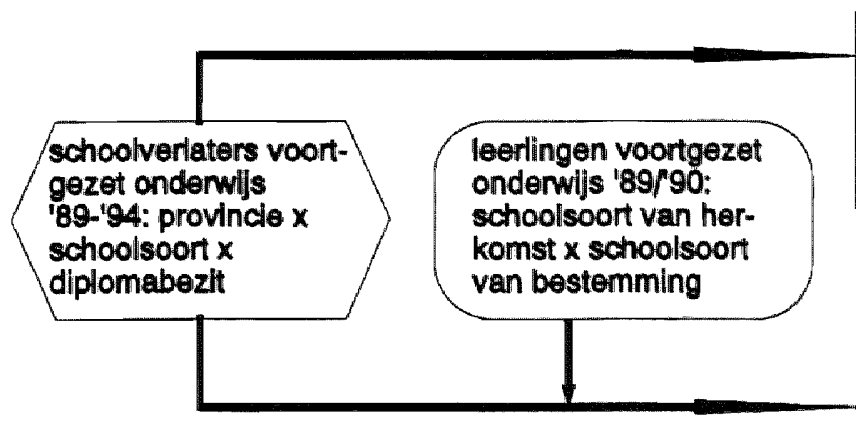

schoolverlaters voortgezet onderwijs met diploma '89-'94: provincie $x$ schoolsoont

schoolverlaters voortgezet onderwijs zonder diploma '89-'94: provincle $x$ schoolsoort van herkomst

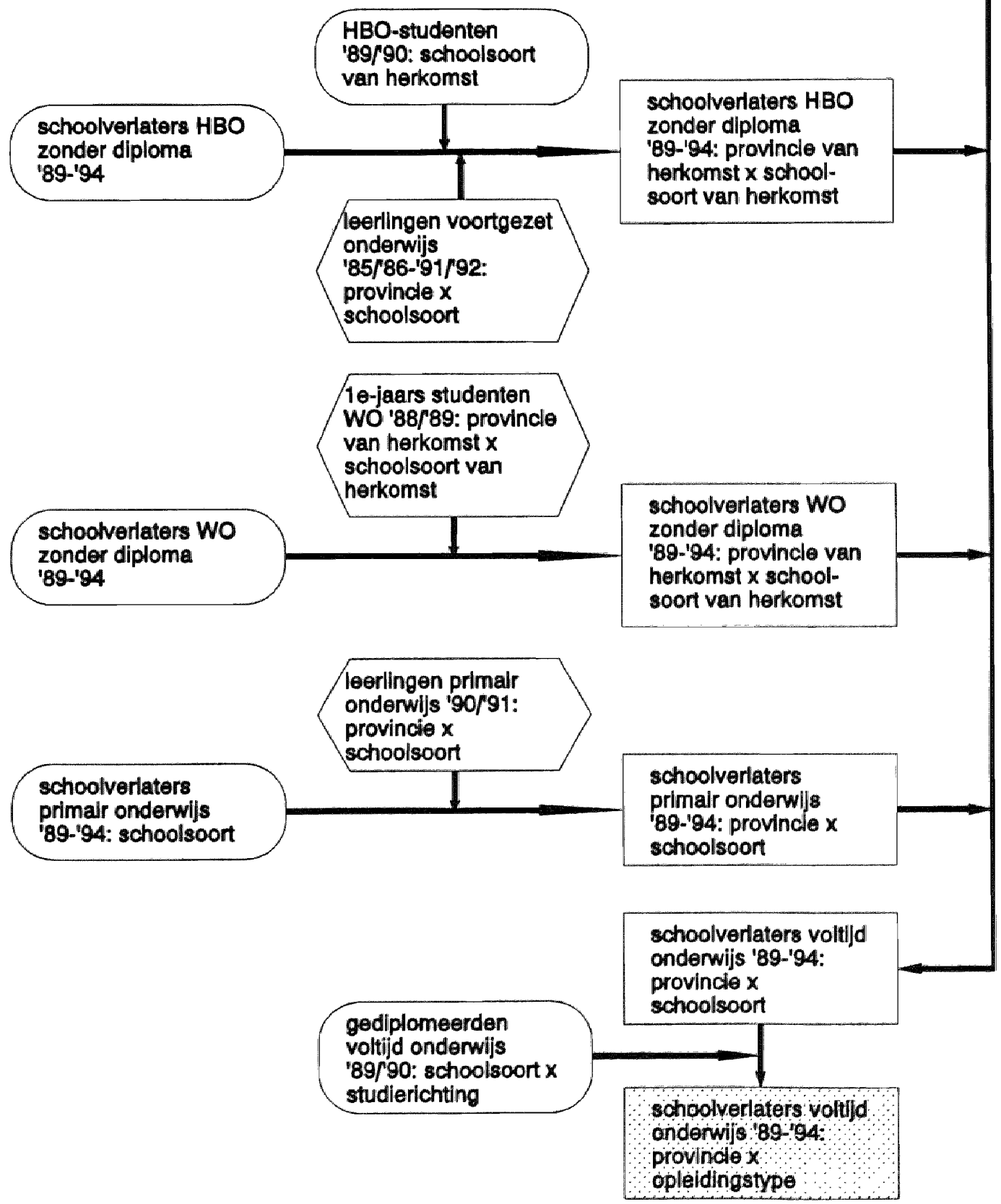


een prognose gemaakt van de toekomstige uitstroom uit het voortgezet onderwijs per provincie $^{18}$. Daarbij is de toekomstige uitstroom onder meer uitgesplitst naar schoolsoort en diplomabezit. Het verwachte aantal gedipiomeerde schoolverlaters per schoolsoort volgt rechtstreeks uit de provinciale RUVO-prognoses. De schoolverlaters zonder diploma moeten echter eerst worden toegerekend aan de schoolsoort waartoe de vooropleiding behoort, die deze schoolverlaters wel met een diploma hebben afgesloten (zie ook Berendsen, Dekker, De Grip en Van de Loo, 1992). Deze toerekening vindt plaats door uit de landelijke onderwijsmatrix 1989 van het CBS voor elke opleiding (schoolsoort van bestemming) in het voortgezet onderwijs de verdeling van de instroom naar vooropleiding (schoolsoort van herkomst) in het schooljaar 1989/1990 te bepalen.

De RUVO-prognoses beperken zich tot de uitstroom uit het voortgezet onderwijs. Er zijn echter ook schoolverlaters die het hoger onderwijs verlaten zonder een diploma te hebben behaald. Voorzover de hoogst voltooide vooropleiding van deze schoolverlaters tot een van de opleidingstypen behoort waarvoor provinciale prognoses worden opgesteld, dient ook deze groep in de prognoses te worden betrokken. Daartoe wordt uitgegaan van de verwachte aantallen ongediplomeerde schoolverlaters van het hoger onderwijs volgens de landelijke SKILLonderwijsprognose van het Ministerie van Onderwijs en Wetenschappen (1990).

De toerekening van de ongediplomeerde schoolverlaters van het $\mathrm{HBO}$ aan hun hoogst voltooide vooropleiding, geschiedt op een wijze die sterk lijkt op de hierboven beschreven manier waarop de schoolverlaters zonder diploma van het voortgezet onderwijs zijn toegerekend aan hun hoogst voltooide vooropleiding (zie ook Berendsen, Dekker, De Grip en Van de Loo, 1992). Uit de onderwijsmatrix 1989 wordt voor het $\mathrm{HBO}$ als geheel de verdeling van de instroom naar vooropleiding (schoolsoort van herkomst) in het schooljaar 1989/1990 afgeleid. Door te veronderstellen dat deze verdeling kan worden geprojecteerd op het verwachte aantal ongediplomeerde HBO-schoolverlaters in de periode 1989-1994, wordt een landelijke prognose verkregen van het aantal ongediplomeerde $\mathrm{HBO}$-schoolverlaters naar hun hoogst voltooide vooropleiding. Deze landelijke prognose dient te worden versleuteld naar provincie. Daartoe wordt gebruik gemaakt van door INRO-TNO verstrekt cijfermateriaal uit de Prognose van de ruimtelijke spreiding in het voortgezet onderwijs 1988/1989 (PRUSO 4) (zie Kuipers, Poulus en Vermeulen, 1989$)^{20}$. Door de provinciale verdeling van de leerlingen in het voortgezet onderwijs te projecteren op de landelijke prognose van het aantal ongediplomeerde HBOschoolverlaters naar hun hoogst voltooide vooropleiding, worden provinciale prognoses

19. In de RUVO-publikatie wordt de vooruitberekening van de toekomstige uitstroom per RBAgebied gepresenteerd, waarbij de cijfers betrekking hebben op de schooljaren 1990/1991 tot en met 2000/2001. Voor onze studie heeft Vermeulen de resultaten verstrekt van de vooruitberekening op provinciaal niveau, waarbij ook de impliciete prognoses voor de schooljaren 1985/1986 tot en met 1989/1990 zijn inbegrepen.

20. Het gaat hier om de naar schoolsoort uitgesplitste prognoses van de leerlingenaantallen per provincie in de schooljaren 1985/1986-1991/1992, waarbij voor het algemeen voorgezet onderwijs en het LBO specifiek wordt uitgegaan van de leerlingen in het laatste leerjaar. 
verkregen van het toekomstig aantal ongediplomeerde $\mathrm{HBO}$-schoolverlaters naar de hoogst voltooide vooropleiding.

Voor het opstellen van de provinciale prognoses van het aantal schoolverlaters zonder diploma van de laatst gevolgde opleiding in het WO naar hoogst voltooide vooropleiding, kan een meer directe weg worden gevolgd. Met behulp van de Statistiek van het wetenschappelijk onderwijs van het CBS (1991a) worden de ongediplomeerde WO-schoolverlaters volgens de landelijke SKILL-prognose toegerekend aan hun hoogst voltooide vooropleiding en aan hun provincie van herkomst. Daarbij wordt gebruik gemaakt van de verdeling van de eerstejaars studenten naar vooropleiding en provincie in het meest recente studiejaar waarover gegevens beschikbaar zijn (1988/1989). Door deze verdeling te projecteren op de SKILL-ramingen van de landellike aantallen ongediplomeerde WO-schoolverlaters in de jaren 1989-1994, resulteren ook voor de ongediplomeerde WO-schoolverlaters provinciale prognoses naar hoogst voltooide vooropleiding.

In de landelijke SKILL-prognose worden naast de schoolverlaters van het voortgezet en het hoger onderwijs ook schoolverlaters in het primair onderwijs (basisonderwijs en (voortgezet) speciaal onderwijs ${ }^{21}$ ) onderscheiden. Om voor het primair onderwijs provinciale schoolverlatersprognoses op te kunnen stellen, wordt op basis van gegevens uit de Statistiek van het basisonderwijs, het speciaal onderwijs en het voortgezet speciaal onderwijs (CBS, 1991b) de provinciale verdeling van de leerlingen in het basis- en (voortgezet) speciaal onderwijs in het schooljaar 1990/1991 bepaald. Door te veronderstellen dat de provinciale verdeling van de leerlingen in dit meest recente schooljaar waarover cijfers beschikbaar zijn ook van toepassing is op de landelijke prognoses, worden provinciale prognoses van het aantal schoolverlaters van het primair onderwijs in de periode 1989-1994 verkregen.

Door de provinciale prognoses van het toekomstig aantal schoolverlaters van het primair onderwijs, het voortgezet onderwijs en de prognoses van de ongediplomeerde schoolverlaters uit het hoger onderwijs met elkaar te combineren, resulteren de vereiste provinciale prognoses van het aantal schoolverlaters van het regulier voltijdonderwijs. Deze prognoses zijn echter niet gedifferentieerd naar ROA-opleidingstype, maar naar schoolsoort. Om tot prognoses per ROAopleidingstype te komen, wordt gebruik gemaakt van de verdeelsleutels die voor het opstellen van de landelijke prognoses in het ROA-informatiesysteem zijn berekend (zie Berendsen. Dekker, De Grip en Van de Loo, 1992). Daarbij wordt verondersteld dat binnen de onderscheiden schoolsoorten voor alle provincies sprake is van dezelfde verdeling naar studierichting. Combinatie van de verdeelsleutels en de provinciale prognoses per schoolsoort resulteert in de provinciale prognoses van het aantal schoolverlaters van het regulier voltijdonderwijs per ROAopleidingstype. Dit is het eindresultaat van stap 1 van de ramingsmethodiek.

Zoals reeds is opgemerkt, stromen de schoolverlaters van het regulier voltijdonderwijs nogal eens door naar het niet-regulier voltijdonderwijs en het (regulier en niet-regulier) deeltijdonderwijs, waaronder diverse vormen van beroepsgerichte volwasseneneducatie. Deze

21. Beide schoolsoorten worden tot het ROA-opleidingstype 'Basisonderwijs' gerekend. 
doorstroom wordt in de tweede stap van de ramingsmethodiek verdisconteerd (zie figuur 3.4.). Daarvoor wordt, op basis van de (tussenjresultaten van het landelijke informatiesysteem, per ROA-opleidingstype berekend welk deel van de schoolverlaters van het regulier voltijdonderwijs in een later stadium een diploma van een deeltijdopleiding of een niet-reguliere voltijdopleiding behaalt. Daarbij blijft het KMBO en het Leerlingwezen buiten beschouwing, orndat hiervoor afzonderlijke provinciale prognoses kunnen worden opgesteld. Er wordt hierbij verondersteld dat de berekende 'doorstroompercentages' per opleidingstype voor alle provincies gelijk zijn ${ }^{22}$.

Figuur 3.4. Methodiek regionale prognose instroom van schoolverlaters, stap 2

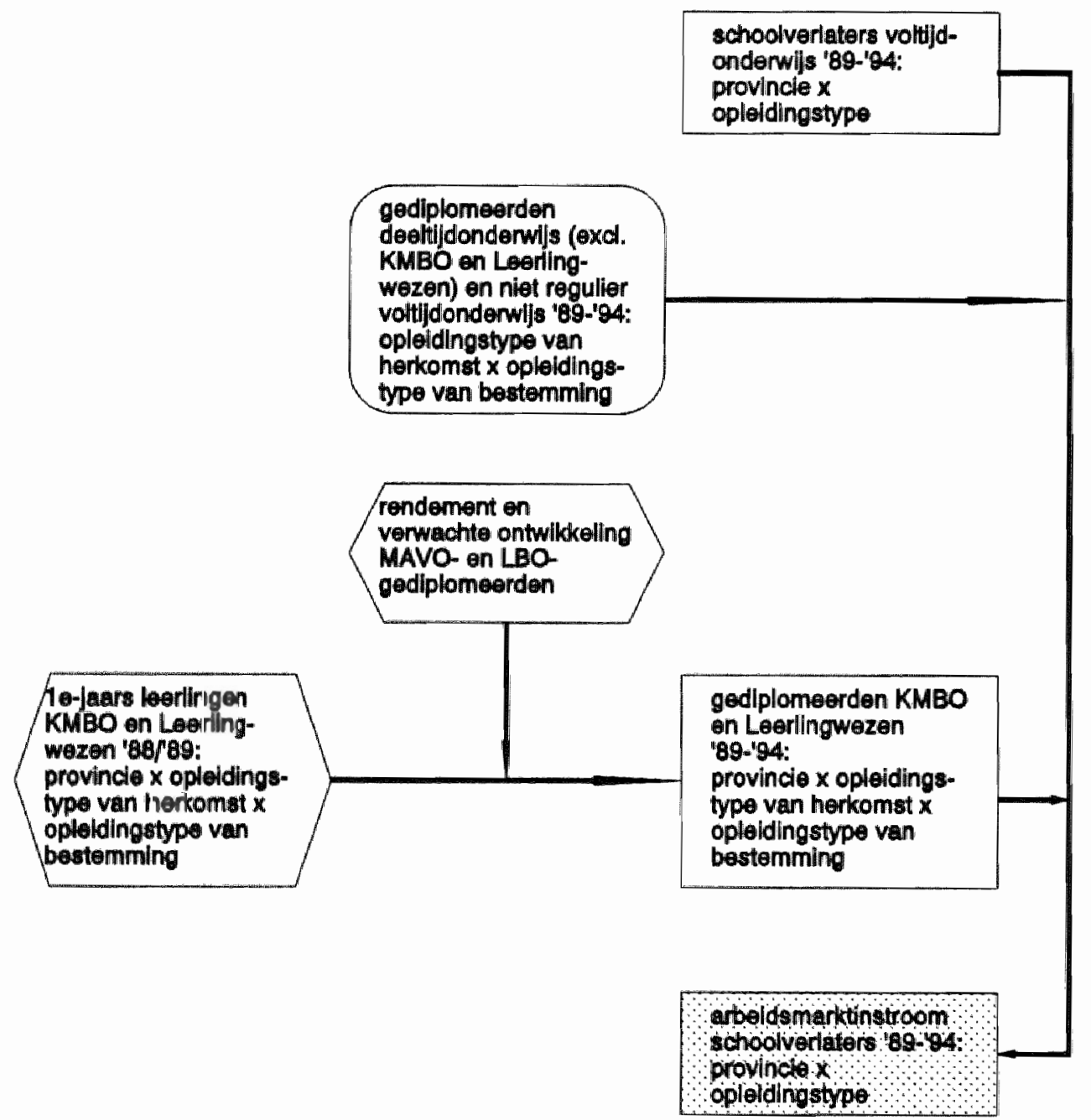

22. De gevolgde werkwijze houdt in dat onder andere impliciete regionale prognoses zijn opgesteld van de gediplomeerde uitstroom uit het in-service onderwijs. Het Nationaal Ziekenhuisinstituut werkt momenteel aan het opstellen van afzonderlijke regionale prognoses met betrekking tot dit in-service onderwijs. Aangezien deze bij het afsluiten van deze studie helaas nog niet beschikbaar waren, konden ze niet in ons onderzoek worden ingepast. 
Voor het KMBO en het Leerlingwezen kunnen, zoals gezegd, afzonderlijke provinciale prognoses worden opgesteld. Dit gebeurt door uit het databestand van het Ministerie van Onderwijs on Wetenschappen met betrekking tot Onderwijsinstellingen, Vormingswerk en Leerlingenaantallen (OVL) het aantal eerstejaars leerlingen in het KMBO en het Leerlingwezen in het schooljaar $1988 / 1989$ te berekenen. Daarbij vindt een uitsplitsing plaats naar provincie, vooropleiding (opleidingstype van herkomst) en cursussoort (opleidingstype van bestemming). Vervolgens wordt op basis van de verwachte leerlingenaantallen uit het bovengenoemde PRUSO 4onderzoek voor elke provincie een correctiefactor berekend, die de verwachte afname van het aantal MAVO- en LBO-gediplomeerden weergeeft. Evenals bij het opstellen van de landelijke prognoses, wordt uitgegaan van een rendement van $70 \%$ voor alle cursussoorten, waarbij wordt verondersteld dat er geen verschillen tussen de provincies bestaan. Door het aantal eerstejaars leerlingen in 1988/1989 te vermenigvuldigen met de correctiefactoren en het rendement, resulteren provinciale prognoses van het toekomstig aantal gediplomeerden van het KMBO en het Leerlingwezen per opleidingstype. Door de prognoses met betrekking tot enerzijds het deeltijdonderwijs en het niet-regulier voltijdonderwijs en anderzijds het KMBO en het Leerlingwezen te combineren met de prognoses van de schoolverlaters van het voltijdonderwijs (het eindresultaat van stap 1) wordt het vereiste eindresultaat verkregen: provinciale prognoses van de arbeidsmarktinstroom van schoolverlaters per ROA-opleidingstype in de periode 19891994.

\section{Prognoseresultaten instroom per opleidingstype}

In tabel 3.7. wordt voor de vier geselecteerde opleidingstypen een overzicht gegeven van de verwachte instroom van schoolverlaters op de arbeidsmarkt in de periode 1989-1994. De verwachte instroom is daarbij zowel in absolute als in relatieve zin weergegeven. Met betrekking tot de procentuele instroom van schoolverlaters van het opleidingstype 'MAVO en onderbouw HAVO/VWO' worden slechts geringe verschillen tussen de provincies verwacht. Ook voor het opleidingstype 'LBO Technisch' is de spreiding van de verwachte provinciale instroompercentages vrij gering. Bij dit opleidingstype valt met name de provincie Overijssel op met een in vergelijking tot het landelijke cijfer lage verwachte instroom van schoolverlaters. Voor NoordHolland wordt voor dit opleidingstype daarentegen juist een, ten opzichte van het landelijke cijfer, relatief hoge arbeidsmarktinstroom verwacht.

De opleidingstypen 'MBO Technisch' en 'MBO Economisch \& Administratief' vertonen ietwat grotere verschillen tussen de verwachte provinciale arbeidsmarktinstroom. Afgezet tegen het landelijke beeld valt bij het opleidingstype 'MBO Technisch' vooral op dat voor de provincie Limburg een lage instroom van schoolverlaters op de arbeidsmarkt wordt verwacht. Voor dit opleidingstype is de instroom van schoolverlaters naar verwachting met name in de provincies Drenthe, Overijssel en Zeeland relatief hoog. Bij het opleidingstype 'MBO Economisch \& Administratief' wordt vooral voor de provincies Utrecht en Noord-Holland een, in vergelijking met het landelijke percentage, lage arbeidsmarktinstroom van schoolverlaters verwacht. De provincies Friesland, Drenthe en Overijssel worden daarentegen gekenmerkt door een relatief hoge toekomstige instroom. 
Tabel 3.7. Instroom van schoolverlaters per opleidingstype en provincie 1989-1994

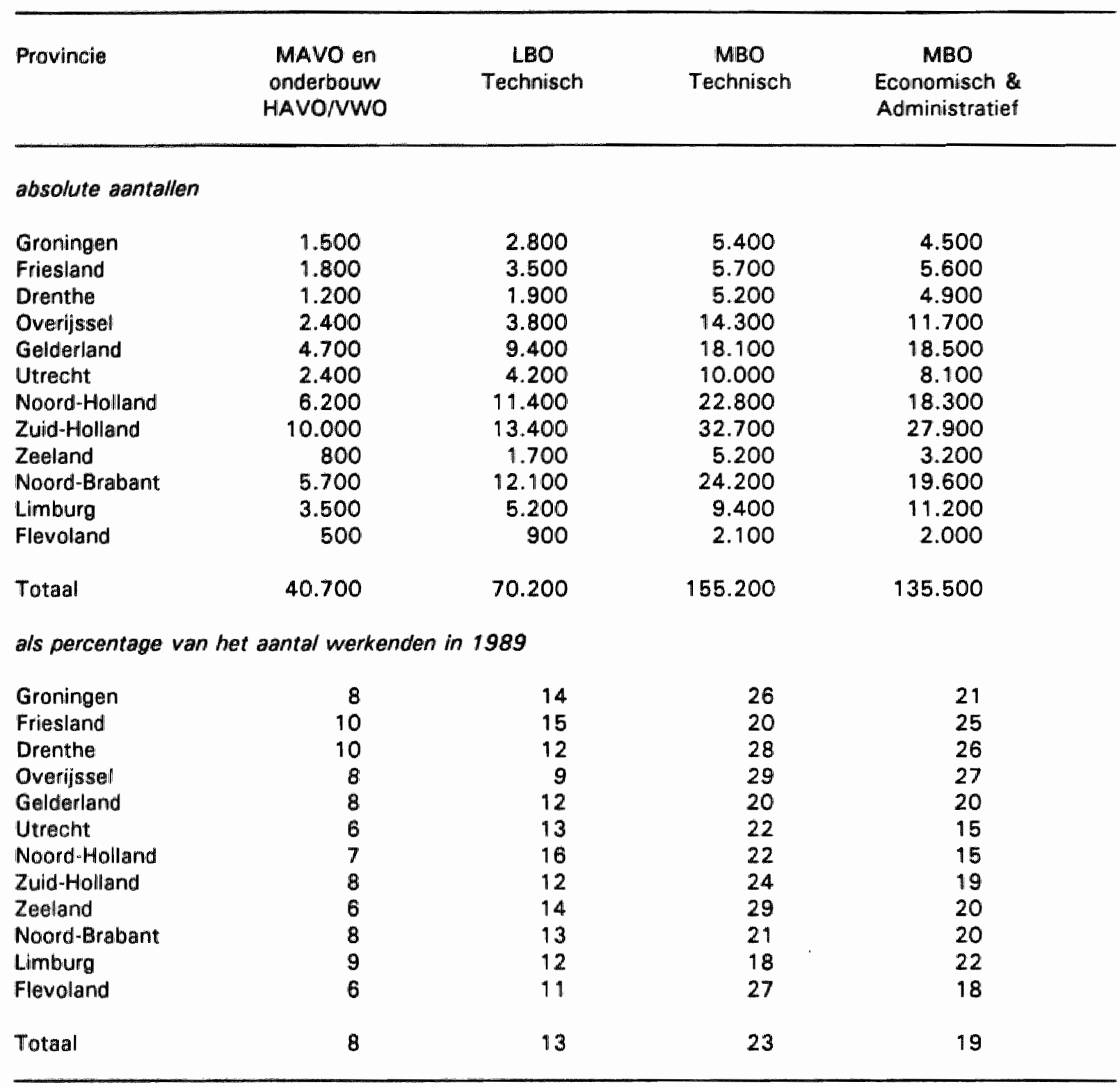

Bron: ROA

\subsection{Typering toekomstige arbeidsmarktsituatie}

In deze paragraaf zal een indicatie worden gegeven van de verwachte toekomstige arbeidsmarktsituatie per opleidingstype. Dit gebeurt aan de hand van de door het ROA ontwikkelde indicator toekomstige arbeidsmarktsituatie (ITA). Daarbij wordt een confrontatie gemaakt van enerzijds de uitbreidings- en vervangingsvraag en anderzijds de verwachte instroom van schoolverlaters op de arbeidsmarkt en het arbeidsaanbod van arbeidskrachten die aan het begin van de prognoseperiode werkloos zijn. Bij deze laatste groep wordt alleen rekening gehouden met werklozen die korter dan 1 jaar werkloos zijn, vanuit de veronderstelling dat personen die langer dan 1 jaar werkloos zijn niet als concurrerend kunnen worden beschouwd voor schoolverlaters met dezelfde opleidingsachtergrond. Indien de indicator 
toekomstige arbeidsmarktsituatie een waarde van 1 heeft, betekent dit dat de toekomstige vraag en het toekomstige aanbod in evenwicht zijn. De kwalitatieve typeringen van de verwachte arbeidsmarktsituatie per opleidingstype die door middel van de indicator kunnen worden toegekend, zijn gebaseerd op de onderstaande indeling (zie voor een nadere toelichting Dekker, De Grip, Berendsen, Wieling en Willems, 1992/23.

$$
\begin{aligned}
\text { ITA } \leq 1,00 & \text { goed arbeidsmarktperspectief } \\
1,00<\text { ITA } \leq 1,05 & \text { redelijk arbeidsmarktperspectief } \\
1,05<\text { ITA } \leq 1,10 & \text { matig arbeidsmarktperspectief } \\
1,10<\text { ITA } & \text { slecht arbeidsmarktperspectief }
\end{aligned}
$$

Zoals reeds eerder is opgemerkt, wordt bij het typeren van de provinciale arbeidsmarktsituatie per opleidingstype geen rekening gehouden met de mogelijke interregionale mobiliteitsstromen. De prognoseresultaten geven derhalve in feite een indicatie van de regionale verschillen in de verwachte arbeidsmarktpositie en de richting van de mobiliteitsstromen die vereist zijn om regionale verschillen te vereffenen. Derhalve wordt de provinciale indicator toekomstige arbeidsmarktsituatie alleen besproken in vergelijking met de landelijke indicator voor het desbetreffende opleidingstype.

Tabel 3.8. Toekomstige arbeidsmarktsituatie per opleidingstype en provincie 1989-1994

\begin{tabular}{lcccc}
\hline Provincie & $\begin{array}{c}\text { MAVO en } \\
\text { onderbouw } \\
\text { HAVO/VWO }\end{array}$ & $\begin{array}{c}\text { LBO } \\
\text { Technisch }\end{array}$ & $\begin{array}{c}\text { MBO } \\
\text { Technisch }\end{array}$ & $\begin{array}{c}\text { MBO } \\
\text { Economisch \& } \\
\text { Administratief }\end{array}$ \\
\hline Groningen & 1,01 & 1,15 & 1,15 & 0,97 \\
Friesland & 1,01 & 1,18 & 1,07 & 1,00 \\
Drenthe & 0,99 & 1,12 & 1,16 & 1,03 \\
Overijssel & 0,99 & 1,05 & 1,15 & 1,02 \\
Gelderland & 0,97 & 1,08 & 1,07 & 0,97 \\
Utrecht & 0,94 & 1,01 & 1,05 & 0,90 \\
Noord-Holland & 1,02 & 1,11 & 1,08 & 0,93 \\
Zuid-Holland & 1,00 & 1,08 & 1,12 & 0,97 \\
Zeeland & 0,95 & 1,14 & 1,16 & 0,98 \\
Noord-Brabant & 0,98 & 1,09 & 1,10 & 0,97 \\
Limburg & 0,99 & 1,10 & 1,06 & 0,99 \\
Flevoland & 0,96 & 1,05 & 1,11 & 0,92 \\
Total & 0,99 & 1,09 & 1,10 & 0,96 \\
\hline
\end{tabular}

Bron: ROA

Uit tabel 3.8. blijkt dat de typering van de toekomstige arbeidsmarktsituatie voor de opleidingstypen 'MAVO en onderbouw HAVONWO' rond de grens van de typeringen 'goed' en 'redelijk' liggen. De op landelijk niveau verwachte goede arbeidsmarktperspectieven zijn in

23. Deze indeling is onder meer afgeleid van de spreiding van de landelijke indicatoren. 
vrijwel alle provincies terug te vinden. Uitzondering hierop vormen de provincies Groningen, Friesland en Noord-Holland, waar de toekomstige arbeidsmarktsituatie naar verwachting ietwat minder gunstig is. Het opleidingstype 'LBO Technisch', waarbij de verwachte arbeidsmarktsituatie op landelijk niveau als 'matig' wordt getypeerd, laat tussen de verschillende provincies een grotere variatie zien met betrekking tot de typering van de toekomstige arbeidsmarktsituatie. Het valt met name op dat de drie noordelijke provincies en Zeeland worden gekenmerkt door een slechtere toekomstige arbeidsmarktsituatie. Daarentegen zijn de arbeidsmarktperspectieven voor met name de provincie Utrecht naar verwachting veel gunstiger, hetgeen voornamelijk wordt veroorzaakt door een naar verwachting minder ongunstige werkgelegenheidsontwikkeling voor deze provincie. Ook voor de provincies Overijssel en Flevoland zijn de arbeidsmarktverwachtingen voor dit opleidingstype relatief gunstig ten opzichte van de landelijke verwachtingen voor dit opleidingstype.

Ook bij het opleidingstype 'MBO Technisch' is er sprake van grote verschillen tussen de provincies in de typering van de toekomstige arbeidsmarktsituatie. In de provincies Groningen, Drenthe, Overijssel en Zeeland is er duidelijk sprake van slechtere toekomstige arbeidsmarktperspectieven dan landelijk voor dit opleidingstype geldt. Daarentegen vertonen de provincies Utrecht en Limburg een gunstiger beeld voor de toekomst, vergeleken met de landelijke verwachtingen voor dit opleidingstype. Overeenkomstig de landelijke typering van de toekomstige arbeidsmarktsituatie voor het opleidingstype 'MBO Economisch \& Administratief' worden voor vrijwel alle provincies goede arbeidsmarktperspectieven verwacht. Uitzonderingen daarop vormen de provincies Drenthe en Overijssel, waar de arbeidsmarktperspectieven naar verwachting wat minder gunstig zijn. Bij de provincie Drenthe wordt dit veroorzaakt door een relatief lage vervangingsvraag, terwijl voor Overijssel geldt dat de minder gunstige arbeidsmarktperspectieven het gevolg zijn van de hoge verwachte instroom van schoolverlaters. Met name voor de provincies Utrecht, Flevoland en Noord-Holland wordt een krappe arbeidsmarkt voor dit opleidingstype verwacht.

\subsection{Samenvatting en conclusies}

In dit hoofdstuk zijn de landelijke middellange-termijn arbeidsmarktprognoses van het ROA gedifferentieerd naar provincie. Daarbij zijn alleen prognoses opgesteld voor de beroepsklassen en opleidingstypen met tenminste 5.000 werkenden (zie respectievelijk bijlage $B$ en $C$ voor een overzicht van deze beroepsklassen en opleidingstypen). Bovendien blijven de opleidingstypen op HBO- en WO-niveau, alsmede het opleidingstype 'MBO Politie \& Defensie' buiten beschouwing, aangezien voor deze opleidingen niet of nauwelijks sprake is van een regionale arbeidsmarkt.

Bij het opstellen van de regionale prognoses is gekozen voor een aanpak, waarbij de landelijke prognoseresultaten worden verdeeld naar de provincies. Daartoe is gebruik gemaakt van enerzijds de onderliggende (tussen)resultaten van de landelijke ROA-prognosemodellen en anderzijds de resultaten van enkele bestaande 'externe' (provinciale) prognosestudies. Tevens is gebruik gemaakt van verschillende naar provincie verbijzonderde actuele data. Zo is bij de prognose van de uitbreidingsvraag rekening gehouden met de provinciale werkgelegenheids- 
structuur per bedrijfsklasse en de verwachte ontwikkelingen daarin. Voor de prognose van de toekomstige vervangingsvraag is gebruik gemaakt van de geslachts- en leeftijdsstructuur van de provinciale werkgelegenheid per beroepsklasse en opleidingstype. De prognose van de toekomstige instroom van schoolverlaters komt tot stand door naast de provinciale instroom uit het voltijdonderwijs rekening te houden met het deeltijdonderwijs en de beroepsgerichte volwasseneneducatie. Deze aanpak zorgt er aan de ene kant voor dat de modellen vrij robuust zijn, met andere woorden dat de onbetrouwbaarheid van de prognoseresultaten als gevolg van in verregaande mate gedetailleerde werkgelegenheidscijfers wordt beperkt. Aan de andere kant worden de verwachte verschillen in de relatieve ontwikkeling tussen de provincies als gevolg van deze 'conservatieve' aanpak mogelijk enigszins onderschat.

In de regionale prognosemodellen is de geografische mobiliteit van arbeidskrachten, die het gevolg zou kunnen zijn van geconstateerde verschillen in de regionale arbeidsmarktsituatie voor een bepaald opleidingstype, niet opgenomen. Bij de interpretatie van de prognoseresultaten moet hiermee vanzelfsprekend rekening worden gehouden, in die zin dat de provinciale prognoses moeten worden afgezet tegen de landelijke prognoseresultaten. Net als bij de verschillen in de verwachte arbeidsmarktsituatie voor opleidingstypen binnen een bepaalde regio, wordt op deze wijze aangegeven welke aanpassingsprocessen noodzakelijk zijn orn vraag en aanbod op een bepaald segment van de arbeidsmarkt weer in evenwicht te brengen. Dit betekent dat in aanvulling op de op landelijk niveau reeds geconstateerde noodzaak tot verschuivingen in het studiekeuzegedrag van jongeren, de om- of bijscholing van arbeidskrachten, of het recruteringsgedrag van werkgevers, ook een beeld kan worden geschetst van de redelijkerwijs te verwachten, c.q. te stimuleren regionale arbeidsmobiliteit voor een bepaald opleidingstype.

Op grond van het bovenstaande kan worden geconcludeerd dat het mogelijk is provinciale arbeidsmarktprognoses op te stellen voor de beroepskiassen en opleidingstypen met tenminste 5.000 werkenden. Daarbij valt op dat de doorgaans kleine verschillen in de samenstelling van de werkzame bevolking naar sector, beroep, opleiding en leeftijd, in combinatie met de verschillen in de arbeidsmarktinstroom van schoolverlaters, inderdaad kunnen leiden tot relevante regionale verschillen in de voor de nabije toekomst te verwachten arbeidsmarktsituatie. Een verdergaande detaillering naar RBA-niveau is in principe mogelijk. Daarbij moet er wel rekening mee worden gehouden dat de betrouwbaarheid van de prognose-uitkomsten kleiner zal zijn dan bij regionalisering op provincieniveau, samenhangend met de lagere 'dekkingsgraad' van de brondata die moeten worden gebruikt voor de regionale uitbreidingsvraagprognose. Bovendien zullen op RBA-niveau voor minder beroepsklassen en opleidingstypen prognoses worden gepresenteerd dan op landelijk niveau mogelijk is, omdat er bij een verdergaande regionale verbijzondering in veel minder beroepsklassen en opleidingstypen tenminste 5.000 werkenden zijn. Enkele grotere RBA-gebieden, zoals Amsterdam/Zaanstreek/Waterland, Den Haag/Delft en Rijnmond vormen hierop enigszins een uitzondering (zie bijlage A). Voor deze RBA-gebieden kan wellicht wel een indicatie van de toekomstige arbeidsmarktsituatie worden gegeven. Voorts kunnen misschien op een hoger aggregatieniveau van beroepen en opleidingen prognoses op RBA-niveau worden opgesteld. 



\section{BESLUIT}

In hoofdstuk 1 is de centrale vraagstelling van dit rapport uiteengezet. Het uitgangspunt is te onderzoeken of het wenselijk en mogelijk is het landelijke ROA-informatiesysteem onderwijsarbeidsmarkt te regionaliseren. Om op deze vraag een antwoord te geven is een onderzoeksmethode gehanteerd waarbij is getracht de regionalisering van de arbeidsmarktinformatie daadwerkelijk te realiseren. De knelpunten die daarbij kunnen optreden, worden op deze wijze inzichtelijk gemaakt.

Het landelijke informatiesysteem bestaat uit twee onderdelen. Het eerste deel bevat een groot aantal actuele gegevens en arbeidsmarktindicatoren. Het tweede deel bestaat uit middellangetermijn prognoses van vraag en aanbod op de arbeidsmarkt. In beide delen hebben de gegevens betrekking op relatief lage aggregatieniveaus van beroepsklassen en opleidingstypen. Ook voor een regionaal informatiesysteem is deze tweedeling als uitgangspunt gekozen. Bovendien is uitgegaan van dezelfde mate van detaillering van de beroeps- en opleidingsgegevens. Daarbij moet wel worden opgemerkt dat de HBO- en WO-opleidingen, alsmede de politie- en defensieopleidingen op MBO-niveau buiten beschouwing zijn gebleven, aangezien voor deze opleidingen (vrijwel) geen sprake is van regionaal afgebakende arbeidsmarkten. De regionale invalshoek in dit rapport is het provincieniveau. Wel is nagegaan of een detaillering naar het niveau van de RBA-gebieden zinvol en mogelijk is.

De actuele data en arbeidsmarktindicatoren zijn aan de orde gekomen in hoofdstuk 2. Daarin is een eerste selectie gemaakt van gegevens die op regionaal niveau zouden kunnen worden gepresenteerd. Aan de hand van de resultaten is het aantal regionale data, waarmee zinvolle arbeidsmarktinformatie zou kunnen worden verstrekt, vervolgens verder teruggebracht. De conclusie is dat de actuele data en arbeidsmarktindicatoren in het regionaal informatiesysteem moeten worden beperkt tot enkele 'kerncijfers'. Dit betreft in de eerste plaats de sectorstructuur van de werkgelegenheid in de onderscheiden regio's. Daarnaast is het van belang de regionale werkgelegenheid per beroepsklasse en opleidingstype te presenteren. Een belangrijke aanvulling daarop wordt gevormd door de regionale werkloosheidscijfers per opleidingstype. Ook de regionale verschillen in de conjuncturgevoeligheid van de werkgelegenheid geven zinvolle additionele informatie ten opzichte van het landelijke informatiesysteem.

Het is van belang om op te merken dat de actuele arbeidsmarktgegevens worden gepresenteerd als een meerjarig gemiddelde. Hierdoor wordt een mogelijke onbetrouwbaarheid van de gegevens als gevolg van steekproeffouten e.d. zoveel mogelijk voorkomen. De opleidingsgegevens hebben echter vooralsnog alleen betrekking op het jaar 1990, aangezien op dit moment geen gedetailleerde cijfers beschikbaar zijn van andere recente jaren.

In hoofdstuk 3 van dit rapport is ingegaan op de regionale arbeidsmarktprognoses. In overeenstemming met het landelijke informatiesysteem is daarbij een 'stroomcijfer' aanpak gehanteerd, waarbij afzonderlijke prognoses worden opgesteld van de uitbreidingsvraag, de vervangingsvraag en de instroom van schoolverlaters op de arbeidsmarkt. Bij alle drie de 
componenten is er voor gekozen om geen (nieuwe) statistische modellen te ontwikkelen, maar zijn de (tussen)resultaten van het landelijke informatiesysteem gecombineerd met additionele regionale gegevens en bestaande regionale prognoses. De gekozen aanpak maakt de regionale prognosemodellen vrij robuust. Wel worden de verschillen in de verwachte ontwikkelingen tussen de provincies mogelijk iets onderschat.

De regionale uitbreidingsvraagprognose per beroepsklasse komt tot stand door de verwachte ontwikkeling van de regionale werkgelegenheid per bedrijfsklasse te relateren aan de verwachte ontwikkeling van de werkgelegenheid per bedrijfsklasse en beroepsklasse. Om tot de regionale prognose van de werkgelegenheidsontwikkeling per opleidingstype te komen, worden deze cijfers vervolgens gecombineerd met de verwachte landelijke ontwikkeling per opleidingstype binnen de onderscheiden beroepen. Gezien het feit dat in hoofdstuk 2 slechts weinig regionale verschillen in de bedrijfssectorstructuur per beroepsklasse en de beroepsklassestructuur per opleidingstype zijn geconstateerd, kunnen de noodzakelijkerwijs gemaakte veronderstellingen als plausibel worden gekenmerkt. De conclusie luidt derhalve dat regionalisering van de ROAuitbreidingsvraagprognoses mogelijk is.

Voor de prognose van de regionale vervangingsvraag per beroepsklasse en per opleidingstype worden de verwachte landelijke verloopcoëfficiënten per beroepsklasse of opleidingstype en per geslacht en leeftijdscategorie gerelateerd aan de provinciale geslachts- en leeftijdssamenstelling van de werkenden in desbetreffende beroepsklassen en opleidingstypen. Dit gebeurt onder de plausibel geachte veronderstelling dat binnen de geslachts- en leeftijdsgroepen het verloop niet over de provincies varieert. Dit maakt het mogelijk vervangingsvraagprognoses voor de anderscheiden beroepsklassen on opleidingstypen op te stellen. Daarbij moet wel worden opgemerkt dat voor kleine beroepsklassen en opleidingstypen de betrouwbaarheid wellicht minder groot is, vanwege de onvermijdelijke steekproef- en meetfouten in deze in grote mate gedesaggregeerde werkgelegenheidscijfers van de EBB.

De prognose van de regionale instroom van schoolverlaters per opleidingstype op de arbeidsmarkt komt tot stand door gebruik te maken van een groot aantal databronnen. De basis wordt daarbij gevormd door gegevens over de regionale uitstroom vit het voortgezet onderwijs. Daarnaast worden onder meer gegevens gebruikt die betrekking hebben op de 'doorstroom' naar het regulier en niet-regulier deeltijdonderwijs en de volwasseneneducatie. Met uitzondering van het KMBO en het Leerlingwezen betreft dit landelijke doorstroomcoëfficiënten. Op basis van deze methodiek is het mogelijk provinciale prognoses op te stellen. Wel dienen daarvoor enkele belangrijke veronderstellingen te worden gemaakt, waardoor de prognoses met enige voorzichtigheid moeten worden geïnterpreteerd.

Door een confrontatie te maken van enerzijds de verwachte uitbreidings- en vervangingsvraag en anderzijds de instroom van schoolverlaters en het aanbod van kortdurig werklozen, wordt een indicatie verkregen van de toekomstige arbeidsmarktsituatie per opleidingstype in de diverse regio's. Opvallend is dat de doorgaans kleine provinciale verschillen in de werkgelegenheidsstructuur samen met de verschilien in de prognose van de instroom van schoolverlaters op de 
arbeidsmarkt, kunnen leiden tot relevante verschillen in de verwachte toekomstige situatie op de arbeidsmarkt. De prognoseresultaten moeten daarbij echter, nog meer dan landelijk gebeurt, worden gezien als indicaties en niet als puntschattingen. In de eerste plaats bestaat er immers altijd een trade-off tussen de betrouwbaarheid van de prognoseresultaten en de mate van detaillering. Daarnaast is geen rekening gehouden met mogelijke mobiliteitsstromen, die kunnen optreden als gevolg van regionale verschillen in de discrepanties op de arbeidsmarkt. Dit maakt dat de te verwachten regionale onevenwichtigheden op de arbeidsmarkt naar opleidingstype in principe op vijf mogelijke manieren kunnen worden teruggedrongen:

- verschuivingen in het studie- of beroepskeuzegedrag van jongeren;

- om- of bijscholing van reeds werkzame personen of werklozen;

- verschuivingen in het recruteringsgedrag van de vragers van arbeid;

- geografische mobiliteit van de aanbieders van arbeid;

- geografische mobiliteit van de vragers van arbeid (vestigingsplaatsbeleid).

Het bovenstaande overziend, kan worden geconcludeerd dat de in hoofdstuk 1 geformuleerde onderzoeksvraag bevestigend mag worden beantwoord: het is, gezien de waargenomen regionale verschillen, wenselijk en bovendien mogelijk de belangrijkste elementen van het ROAinformatiesysteem onderwijs-arbeidsmarkt te regionaliseren. Bij het prognosedeel moet daarbij duidelijk in ogenschouw worden genomen dat de resultaten indicaties weergeven, die ten opzichte van de landelijke uitkomsten moeten worden gezien.

Ten aanzien van het niveau van regionalisering kan het volgende worden opgemerkt. Voor de meeste provincies kunnen voldoende arbeidsmarktgegevens en -prognoses worden gegenereerd. De verbijzondering van de actuele data en arbeidsmarktindicatoren naar het niveau van de RBAgebieden is in principe mogelijk. Hierbij moet wel worden bedacht dat het aantal beroepsklassen en opleidingstypen, waarvoor gegevens zouden kunnen worden gepresenteerd beduidend kleiner is dan op provincieniveau. Wellicht kan worden overwogen prognoses op RBA-niveau op te stellen op een hoger aggregatieniveau van beroepen en opleidingen. Een andere mogelijkheid kan zijn om voor enkele grote provincies de prognoseresultaten te 'verdelen' naar de onderliggende (grote) RBA-gebieden.

Tot slot kan er op worden gewezen dat het regionaal informatiesysteem onderwijs-arbeidsmarkt ook zou moeten bestaan uit gegevens die op basis van een 'bottom-up' invalshoek worden verzameld. Dit in aanvulling op de gegevens die via 'top-down' benadering, die in deze studie is gevolgd, kunnen worden gegenereerd. Daarbij kan met name worden gedacht aan gebruikmaking van de regionale arbeidsmarktgegevens van de provinciale overheden, de Arbeidsvoorzieningsorganisatie (de RBA's), de Kamers van Koophandel e.d. Ook de grootschalige schoolverlatersenquête RUIBS (Registratie van de Uitstroom en de Bestemming van Schoolverlaters) zou op dit punt zeer waardevolle informatie kunnen opleveren. 


\section{LITERATUUR}

Albeda, W. (1991), Regionaal arbeidsmarktbeleid, in: Scholten, H. (red). Arbeidsmarkt en regio; ruimte voor beleid?, Economisch-Geografisch Instituut, Rotterdam.

Berendsen, H., R.J.P. Dekker, A. de Grip, P.J.E. van de Loo (1992), Prognose arbeidsmarktinstroom van schoolverlaters per opleidingstype, ROA-W-1992/2, Maastricht.

Berendsen, H., A. de Grip, M.H. Wieling, E.J.T.A. Willems (1992a), Arbeidsmarktinformatie naar opleiding en beroep voor de provincie Noord-Holland, ROA-R-1992/3. Maastricht.

Berendsen, H., A. de Grip, M.H. Wieling, E.J.T.A. Willems (1992b), Arbeidsmarktinformatie naar opleiding en beroep voor de provincie Friesland; tabellenoverzicht, ROA-W-1992/4, Maastricht.

Centraal Bureau voor de Statistiek (1991a), Statistiek van het wetenschappelijk onderwijs; de instroom in het studiejaar 1988/'89 regionaal bezien, 's-Gravenhage.

Centraal Bureau voor de Statistiek (1991b), Statistiek van het basisonderwijs, het speciaal onderwijs en het voortgezet speciaal onderwijs 1990/'91; scholen en leerlingen. 'sGravenhage.

Dekker, R.J.P., A. de Grip, H. Berendsen, M.H. Wieling, E.J.T.A. Willems (1992), Methodiek en structuur arbeidsmarktmodule I-See! 1991, ROA-W-1992/1, Maastricht.

Grip, A. de (1991), Meer licht op de regionale arbeidsmarkt, ROA-R-1991/4, Maastricht.

Grip, A. de, J.A.M. Heijke (1989), Het flexibiliteitspotentieel van universitaire studierichtingen, Tijdschrift voor Arbeidsuraagstukken, jrg. 5, nr. 4, blz. 69-81.

Grip, A. de, R.K.W. van der Velden, M.H. Wieling (1991), Indicatoren aans/uiting onderwijsarbeidsmarkt MDGO, ROA-R-1991/2, Maastricht.

Hoof, J.J. van, J. Dronkers (1980), Onderwijs en arbeidsmarkt, Sociologische monografieën, Van Loghum Slaterus, Deventer.

Kuipers, P., C. Poulus, M. Vermeulen (1989), PRUSO 4; prognose van de ruimtelijke spreiding in het voortgezet onderwijs 1988/1989, INRO-TNO, Delft.

Laan, L. van der, H. Scholten, G.A. van der Knaap (1990), Structuur en dynamiek van de (actieve) regionale beroepsbevolking; DYAREB-eindrapport, Economisch-Geografisch Instituut, Rotterdam.

Ministerie van Onderwijs en Wetenschappen (1990), SKILL 1990-II, interne notitie, Zoetermeer.

Ministerie van Sociale Zaken en Werkgelegenheid 11991), Rapportage Arbeidsmarkt 1991, 'sGravenhage.

Natzijl, H.P., P. Westra (1991), Regionale arbeidsmarkt prognose 1991-1996, OAV-rapport 9108, Rijswijk.

Nederlands Economisch Instituut (1985), RESPONS; Een regionaal verdeelmodel van de werkgelegenheid in Nederland, Rotterdam. 
Ooms, I.L., M.J.M. Vermeulen 11991), Ruimtelijke aspecten van substitutie op de arbeidsmarkt, een aanzet tot modelontwikkeling. INRO-TNO, Delft.

Researchcentrum voor Onderwijs en Arbeidsmarkt (1992), De arbeidsmarkt naar opleiding en beroep tot 1994, ROA-R-1992/1, Maastricht.

Vermeulen, M. (1990), Regionalisering uitstroom voortgezet onderwijs (RUVO), INRO-TNO, Delft.

Wieling, M.H., R.J.P. Dekker, A. de Grip (1991), Landelijke en regionale werkloosheidsindicatoren 1991, ROA-R-1991/8, Maastricht.

Wieling, M.H., A. de Grip, E.J.T.A. Willems (1990), Een systematische kwalitatieve typering van arbeidsmarktinformatie, ROA-W-1990/8, Maastricht.

Willems, E.J.T.A., A. de Grip (1990), Vervangingsvraagprognoses naar beroep en opleiding, ROA-W-1990/7, Maastricht. 


\section{BIJLAGE A: ACTUELE DATA EN INDICATOREN PER RBA-GEBIED ${ }^{24}$}

Tabel A.2. Gemiddeld aantal werkenden en gemiddeld percentage van de totale werkgelegenheid per bedrijfssector en RBA-gebied 1989-1990

\begin{tabular}{|c|c|c|c|c|}
\hline RBA-gebied & $\begin{array}{l}\text { Landbouw, } \\
\text { visserij en } \\
\text { bosbouw }\end{array}$ & $\begin{array}{l}\text { Metaal- } \\
\text { industrie }\end{array}$ & Handel & $\begin{array}{r}\text { Openbaar bes } \\
\text { politie er } \\
\text { defensie }\end{array}$ \\
\hline \multicolumn{5}{|l|}{ gemiddeld aantal } \\
\hline Groningen & 10.000 & 13.000 & 30.000 & 19.000 \\
\hline Friesland & 18.000 & 12.000 & 30.000 & 20.000 \\
\hline Drenthe & 13.000 & 12.000 & 24.000 & 15.000 \\
\hline IJssel-Vecht & 11.000 & 8.000 & 20.000 & 11.000 \\
\hline Twente & 9.000 & 17.000 & 32.000 & 15.000 \\
\hline Midden-IJssel & 8.000 & 6.000 & 12.000 & 6.00 \\
\hline Veluwe & 11.000 & 11.000 & 37.000 & 25.000 \\
\hline Arnhem/Oost-Gelderland & 19.000 & 19.000 & 37.000 & 22.000 \\
\hline Nijmegen/Rivierenland & 8.000 & 10.000 & 27.000 & 14.000 \\
\hline Flevoland & 8.000 & & 15.000 & 11.00 \\
\hline Oost-Utrecht & 6.000 & 9.000 & 39.000 & 17.00 \\
\hline Midden- en West-Utrecht & 8.000 & 7.000 & 39.000 & 19.000 \\
\hline Gooi en Vechtstreek & & & 18.000 & 19.000 \\
\hline $\begin{array}{l}\text { Noord-Holland Noord } \\
\text { Amsterdam/Zaanstreek/ }\end{array}$ & \multicolumn{3}{|c|}{ Amsterdam/Zaanstreek/ } & 26.000 \\
\hline Waterland & - & 15.000 & 60.000 & 34.00 \\
\hline \multicolumn{5}{|l|}{ Kennemer-/Amstel- } \\
\hline en Meerlanden & 7.000 & 18.000 & 45.000 & 19.000 \\
\hline Rijnstreek & 19.000 & 11.000 & 55.000 & 30.00 \\
\hline Den Haag/Delft & 24.000 & 10.000 & 52.000 & 61.00 \\
\hline Drechtsteden & - & 12.000 & 24.000 & 13.00 \\
\hline Rijnmond & 11.000 & 21.000 & 77.000 & 36.00 \\
\hline Zeeland & 10.000 & 8.000 & 22.000 & 12.00 \\
\hline Westelijk Noord-Brabant & 5.000 & 6.000 & 13.000 & 7.00 \\
\hline Breda en omstreken & 10.000 & 10.000 & 28.000 & 13.000 \\
\hline Midden-Brabant & 7.000 & 13.000 & 27.000 & 12.00 \\
\hline Noord-Oost Brabant & 16.000 & 15.000 & 34.000 & 17.00 \\
\hline Zuid-Oost Brabant & 11.000 & 18.000 & 37.000 & 17.000 \\
\hline & 22.000 & 26.000 & 13.000 \\
\hline \multicolumn{2}{|c|}{$\begin{array}{l}\text { Midden- en Noord-Limburg18.000 } \\
\text { Zuid-Limburg }\end{array}$} & 15.000 & 34.000 & 21.00 \\
\hline Totaal & 299.000 & 335.000 & 931.000 & 527.000 \\
\hline
\end{tabular}

gemidde/d percentage

$\begin{array}{ll}\text { Groningen } & 5 \\ \text { Friesland } & 8 \\ \text { Drenthe } & 8 \\ \text { IJssel-Vecht } & 8 \\ \text { Twente } & 4 \\ \text { Midden-IJssel } & 9 \\ \text { Veluwe } & 4 \\ \text { Arnhem/Oost-Gelderland } & 7\end{array}$

$\begin{array}{rr}14 & 9 \\ 13 & 9 \\ 14 & 9 \\ 14 & 8 \\ 14 & 7 \\ 14 & 6 \\ 14 & 10 \\ 13 & 8\end{array}$

24. De nummering van de tabellen in deze bijlage komt overeen met de nummering in hoofdstuk 2. 
Tabel A.2. Gemiddeld aantal werkenden en gemiddeld percentage van de totale werkgelegenheid per bedriffssector en RBA-gebied 1989-1990, vervolg

\begin{tabular}{|c|c|c|c|c|}
\hline RBA-gebied & $\begin{array}{l}\text { andbouw, } \\
\text { isserij en } \\
\text { bosbouw }\end{array}$ & $\begin{array}{l}\text { Metaal- } \\
\text { industrie }\end{array}$ & Handel & $\begin{array}{c}\text { Openbaar bestuur, } \\
\text { politie en } \\
\text { defensie }\end{array}$ \\
\hline Nijmegen/Rivierenland & 4 & 5 & 14 & 7 \\
\hline Flevoland & 9 & $=$ & 17 & 12 \\
\hline Oost-Utrecht & 3 & 4 & 18 & 8 \\
\hline Midden- en West-Utrecht & 3 & 3 & 16 & 8 \\
\hline Gooi en Vechtstreek & . & - & 17 & 7 \\
\hline $\begin{array}{l}\text { Noord-Holland Noord } \\
\text { Amsterdam/Zaanstreek/ }\end{array}$ & 8 & 6 & 16 & 10 \\
\hline Waterland & - & 3 & 14 & 8 \\
\hline $\begin{array}{l}\text { Kennemer-/Amstel- } \\
\text { en Meerlanden }\end{array}$ & 3 & 6 & 16 & 7 \\
\hline Rijnstreek & 6 & 3 & 17 & 9 \\
\hline Den Haag/Delft & 6 & 2 & 13 & 15 \\
\hline Drechtsteden & - & 7 & 15 & 8 \\
\hline Rijnmond & 2 & 4 & 16 & 7 \\
\hline Zeeland & 7 & 5 & 15 & 8 \\
\hline Westelijk Noord-Brabant & 5 & 6 & 13 & 7 \\
\hline Breda en omstreken & 6 & 6 & 17 & 8 \\
\hline Midden-Brabant & 4 & 8 & 16 & 7 \\
\hline Noord-Oost Brabant & 7 & 6 & 14 & 7 \\
\hline Zuid-Oost Brabant & 4 & 6 & 13 & 6 \\
\hline Midden- en Noord-Limburg & 9 & 11 & 13 & 7 \\
\hline Zuid-Limburg & - & 6 & 13 & 8 \\
\hline Totaal & 5 & 5 & 15 & 8 \\
\hline - onbekend & & & & \\
\hline
\end{tabular}

Bron: CBS/ROA 
$-54-$

Tabel A.3. Leeftijdsopbouw per RBA-gebied 1989-1990

\begin{tabular}{|c|c|c|c|c|}
\hline RBA-gebied & $\begin{array}{c}\text { Tot } 30 \text { jaar } \\
\%\end{array}$ & $\begin{array}{c}30-39 \text { jaar } \\
\%\end{array}$ & $\begin{array}{c}40-49 \text { jaar } \\
\%\end{array}$ & $\begin{array}{c}\text { Vanaf } 50 \text { jaar } \\
\%\end{array}$ \\
\hline Groningen & 36 & 26 & 23 & 14 \\
\hline Friesland & 36 & 28 & 23 & 14 \\
\hline Drenthe & 34 & 27 & 24 & 15 \\
\hline |Jssel-Vecht & 37 & 26 & 21 & 16 \\
\hline Twente & 37 & 26 & 23 & 14 \\
\hline Midden-IJssel & 34 & 26 & 22 & 18 \\
\hline Veluwe & 37 & 25 & 23 & 15 \\
\hline Arnhem/Oost-Gelderland & 35 & 27 & 23 & 16 \\
\hline Nijmegen/Rivierenland & 35 & 29 & 22 & 14 \\
\hline Flevoland & 37 & 31 & 23 & 9 \\
\hline Oost-Utrecht & 35 & 25 & 24 & 16 \\
\hline Midden- en West-Utrecht & 37 & 30 & 20 & 13 \\
\hline Gooi en Vechtstreek & 33 & 26 & 23 & 18 \\
\hline Noord-Holland Noord & 35 & 27 & 25 & 14 \\
\hline Amsterdam/Zaanstreek/Waterland & 36 & 31 & 20 & 13 \\
\hline Kennemer-/Amstel- en Meerlanden & 34 & 26 & 23 & 17 \\
\hline Rijnstreek & 36 & 27 & 23 & 15 \\
\hline Den Haag/Delft & 33 & 29 & 22 & 16 \\
\hline Drechtsteden & 37 & 26 & 23 & 14 \\
\hline Rijnmond & 36 & 27 & 23 & 14 \\
\hline Zeeland & 34 & 28 & 22 & 16 \\
\hline Westelijk Noord-Brabant & 35 & 28 & 22 & 15 \\
\hline Breda en omstreken & 37 & 27 & 24 & 13 \\
\hline Midden-Brabant & 37 & 27 & 23 & 13 \\
\hline Noord-Oost Brabant & 36. & 27 & 23 & 14 \\
\hline Zuid-Oost Brabant & 37 & 27 & 22 & 14 \\
\hline Midden- en Noord-Limburg & 35 & 27 & 23 & 15 \\
\hline Zuid-Limburg & 34 & 28 & 24 & 15 \\
\hline Totaal & 35 & 27 & 23 & 15 \\
\hline
\end{tabular}

Bron: CBS/ROA 
Tabel A.4. Aantal beroepsklassen waarvoor cijfers over de werkgelegenheid kunnen worden gepresenteerd en het aandeel van deze beroepsklassen in de totale werkgelegenheid ("dekkingsgraad') per RBA-gebied 1989

ABA-gebied

Aantal beroepsklassen

Dekkingsgraad

$\%$

Groningen

48

Friesland

12

13

54

Drenthe

10

43

IJssel-Vecht

9

15

Twente

15

53

Midden-IJssel

17

Veluwe

Arnhem/Oost-Gelderland

64

Nijmegen/Rivierenland

Flevoland

Oost-Utrecht

21

17

58

Midden- en West-Utrecht

2

12

14

51

Gooi en Vechtstreek

14

53

Noord-Holland Noord

36

Amsterdam/Zaanstreek/Waterland

Kennemer-/Amstel- en Meerlanden

Rijnstreek

58

Den Haag/Delft

Drechtsteden

Rijnmond

Zeeland

Westelijk Noord-Brabant

Breda en omstreken

Midden-Brabant

Noord-Oost Brabant

Zuid-Oost Brabant

Midden- en Noord-Limburg

53

Zuid-Limburg

$14 \quad 53$

Totaal

88

98

Bron: CBS/ROA 
Tabel A.5. Gemiddeld aantal werkenden en gemiddeld percentage van de totale werkgelegenheid per beroepsklasse en RBA-gebied 1989-1990

\begin{tabular}{|c|c|c|c|c|c|c|}
\hline \multirow[b]{2}{*}{ RBA-gebied } & \multirow[b]{2}{*}{2011} & \multirow[b]{2}{*}{3721} & \multicolumn{2}{|c|}{ beroepsklassecode } & \multirow[b]{2}{*}{8211} & \multirow[b]{2}{*}{ Totaal } \\
\hline & & & 6124 & 6211 & & \\
\hline \multicolumn{7}{|l|}{ gemidde/d aantal } \\
\hline Groningen & 6.000 & - & 12.000 & 14.000 & 10.000 & 215.000 \\
\hline Friesland & 9.000 & - & 14.000 & 15.000 & 11.000 & 228.000 \\
\hline Drenthe & 7.000 & - & 10.000 & 11.000 & 7.000 & 173.000 \\
\hline IJssel-Vecht & 6.000 & - & 7.000 & 8.000 & 6.000 & 139.000 \\
\hline Twente & 5.000 & - & 13.000 & 16.000 & 10.000 & 221.000 \\
\hline Midden-IJssel & - & - & - & 5.000 & - & 89.000 \\
\hline Veluwe & 8.000 & - & 14.000 & 15.000 & 13.000 & 253.000 \\
\hline Arnhem/Oost-Gelderland & 11.000 & - & 17.000 & 17.000 & 11.000 & 284.000 \\
\hline Nijmegen/Rivierenland & - & - & 10.000 & 10.000 & 7.000 & 192.000 \\
\hline Flevoland & - & - & 6.000 & 5.000 & - & 89.000 \\
\hline Oost-Utrecht & - & - & 12.000 & 14.000 & 8.000 & 220.000 \\
\hline Midden- en West-Utrecht & - & - & 16.000 & 16.000 & 10.000 & 245.000 \\
\hline Gooi en Vechtstreek & - & - & 7.000 & 8.000 & & 107.000 \\
\hline \multicolumn{7}{|l|}{ Amsterdam/Zaanstreek/ } \\
\hline Waterland & - & 7.000 & 29.000 & 23.000 & 20.000 & 423.000 \\
\hline \multicolumn{7}{|l|}{ Kennemer-/Amstel- } \\
\hline en Meerlanden & - & - & 20.000 & 17.000 & 10.000 & 279.000 \\
\hline Rijnstreek & 10.000 & - & 18.000 & 21.000 & 11.000 & 321.000 \\
\hline Den Haag/Delft & 16.000 & 6.000 & 22.000 & 20.000 & 14.000 & 406.000 \\
\hline Drechtsteden & - & - & 9.000 & 10.000 & 6.000 & 158.000 \\
\hline Rijnmand & 7.000 & 11.000 & 32.000 & 30.000 & 19.000 & 481.000 \\
\hline Zeeland & - & - & 8.000 & 10.000 & 7.000 & 147.000 \\
\hline Westelijk Noord-Brabant & - & - & 5.000 & 6.000 & - & 99.000 \\
\hline Breda en omstreken & 5.000 & - & 8.000 & 11.000 & 6.000 & 166.000 \\
\hline Midden-Brabant & 5.000 & - & 8.000 & 11.000 & 6.000 & 166.000 \\
\hline Noord-Oost Brabant & 8.000 & - & 11.000 & 12.000 & 10.000 & 240.000 \\
\hline Zuid-Oost Brabant & 6.000 & 5.000 & 15.000 & 17.000 & 11.000 & 277.000 \\
\hline \multicolumn{2}{|c|}{ Midden- en Noord-Limburg 10.000} & - & 11.000 & 12.000 & 9.000 & 200.000 \\
\hline \multicolumn{2}{|c|}{ Zuid-Limburg } & - & 14.000 & 16.000 & 12.000 & 254.000 \\
\hline Totaal & 68.000 & 101.000 & 363.000 & 386.000 & 251.000 & 6.318 .000 \\
\hline
\end{tabular}

gemiddeld percentage

Groningen
Friesland
Drenthe
IJssel-Vecht
Twente
Midden-IJssel
Veluwe
Arnhem/Oost-Gelderland
Nijmegen/Rivierenland
Flevoland
Oost-Utrecht
Midden- en West-Utrecht
Gooi en Vechtstreek
Noord-Holland Noord
Amsterdam/Zaanstreek
Waterland


Tabel A.5. Gemiddeld aantal werkenden en gemiddeld percentage van de totale werkgelegenheid per beroepsklasse en RBA-gebied 1989-1990, vervolg

\begin{tabular}{|c|c|c|c|c|c|c|}
\hline \multirow[b]{2}{*}{ RBA-gebied } & \multirow[b]{2}{*}{2011} & \multirow[b]{2}{*}{3721} & \multicolumn{2}{|c|}{ beroepsklassecode } & \multirow[b]{2}{*}{8211} & \multirow[b]{2}{*}{ Totaal } \\
\hline & & & 6124 & 6211 & & \\
\hline \multicolumn{7}{|l|}{ Kennemer-/Amstel- } \\
\hline en Meerlanden & - & - & 7 & 6 & 3 & 100 \\
\hline Rijnstreek & 3 & - & 5 & 6 & 3 & 100 \\
\hline Den Haag/Delft & 4 & 1 & 5 & 5 & 3 & 100 \\
\hline Drechtsteden & - & - & 6 & 6 & 4 & 100 \\
\hline Rijnmond & 1 & 2 & 7 & 6 & 4 & 100 \\
\hline Zeeland & - & . & 5 & 6 & 4 & 100 \\
\hline Westelijk Noord-Brabant & . & - & 5 & 6 & - & 100 \\
\hline Breda en omstreken & 3 & - & 5 & 6 & 3 & 100 \\
\hline Midden-Brabant & 3 & . & 5 & 7 & 4 & 100 \\
\hline Noord-Oost Brabant & 3 & - & 5 & 5 & 4 & 100 \\
\hline Zuid-Oost Brabant & 2 & 2 & 5 & 6 & 4 & 100 \\
\hline Midden- en Noord-Limburg & 5 & - & 6 & 6 & 4 & 100 \\
\hline Zuid-Limburg & - & - & 6 & 6 & 5 & 100 \\
\hline Totaal & 3 & 2 & 6 & 6 & 4 & 100 \\
\hline - = onbekend & & & & & & \\
\hline
\end{tabular}

2011 Uitvoerend agrarisch personeel, bosarbeiders

3721 Elektriciens, elektro- en telecom(onderhouds)monteurs

6124 Boekhoudkundige, belasting-, loket- en bankemployees

6211 Winkel-, straat- en marktverkopers, demonstrateurs

8211 Portiers, schoonmaak- e.a. lager dienstverlenend personeel

Bron: CBS/ROA 
Tabel A.6. Aantall opleidingstypen waarvoor cijfers over de werkgelegenheid kunnen worden gepresenteerd per RBA-gebied 1990

RBA-gebied

Aantal opleidingstypen

$\begin{array}{lr}\text { Groningen } & 10\end{array}$

\begin{tabular}{ll} 
Friesland & 12 \\
\hline
\end{tabular}

$\begin{array}{ll}\text { Drenthe } & 11\end{array}$

IJssel-Vecht $\quad 9$

Twente 11

Midden-IJssell

$\begin{array}{ll}\text { Veluwe } & 11\end{array}$

$\begin{array}{lr}\text { Arnhem/Oost-Gelderland } & 12\end{array}$

Nijmegen/Rivierenland $\quad 9$

Flevoland

$\begin{array}{lr}\text { Oost-Utrecht } & 10\end{array}$

$\begin{array}{lr}\text { Midden- en West-Utrecht } & 10\end{array}$

Gooi en Vechtstreek $\quad 6$

Noord-Holland Noord $\quad 12$

Amsterdam/Zaanstreek/Waterland 10

Kennemer-/Amstel- en Meerlanden $\quad 10$

\begin{tabular}{ll} 
Rijnstreek & 12 \\
\hline
\end{tabular}

Den Haag/Delft $\quad 12$

Drechtsteden $\quad 9$

Rijnmond $\quad 12$

$\begin{array}{lr}\text { Zeeland } & 9\end{array}$

$\begin{array}{ll}\text { Westellijk Noord-Brabant } & 7\end{array}$

$\begin{array}{lr}\text { Breda en omstreken } & 9\end{array}$

Midden-Brabant $\quad 9$

Noord-Oost Brabant $\quad 11$

$\begin{array}{ll}\text { Zuid-Oost Brabant } & 11\end{array}$

Midden- en Noord-Limburg $\quad 11$

$\begin{array}{lr}\text { Zuid-Limburg } & 10\end{array}$

$\begin{array}{ll}\text { Totaal } & 20\end{array}$

Bron: CBS/ROA 
Tabel A.7. Aantal werkenden en percentage van de totale werkgelegenheid per opleidingstype en RBAgebied 1990

\begin{tabular}{lcccc}
\hline RBA-gebied & $\begin{array}{c}\text { MAVO en } \\
\text { onderbouw } \\
\text { HAVONWWO }\end{array}$ & $\begin{array}{c}\text { LBO } \\
\text { Technisch }\end{array}$ & $\begin{array}{c}\text { MBO } \\
\text { Technisch }\end{array}$ & $\begin{array}{c}\text { MBO } \\
\text { Economisch \& } \\
\text { Administratief }\end{array}$ \\
\hline
\end{tabular}

aantal

$\begin{array}{lrrrr}\text { Groningen } & 19.000 & 20.000 & 21.000 & 22.000 \\ \text { Friesland } & 17.000 & 23.000 & 28.000 & 22.000 \\ \text { Drenthe } & 12.000 & 16.000 & 19.000 & 19.000 \\ \text { IJssel-Vecht } & 11.000 & 14.000 & 16.000 & 15.000 \\ \text { Twwente } & 17.000 & 25.000 & 28.000 & 23.000 \\ \text { Midden-IJssel } & 5.000 & 7.000 & 11.000 & 10.000 \\ \text { Veluwe } & 22.000 & 24.000 & 29.000 & 32.000 \\ \text { Arnhem/Oost-Gelderland } & 21.000 & 30.000 & 34.000 & 37.000 \\ \text { Nijmegen/Rivierenland } & 14.000 & 19.000 & 22.000 & 21.000 \\ \text { Flevoland } & 9.000 & 8.000 & 8.000 & 11.000 \\ \text { Oost-Utrecht } & 21.000 & 16.000 & 21.000 & 28.000 \\ \text { Midden- en West-Utrecht } & 20.000 & 17.000 & 23.000 & 25.000 \\ \text { Gooi en Vechtstreek } & 9.000 & 6.000 & 9.000 & 11.000 \\ \text { Noord-Holland Noord } & 23.000 & 20.000 & 30.000 & 29.000 \\ \text { Amsterdam/Zaanstreek/ } & & & & \\ \text { Waterland } & 37.000 & 26.000 & 35.000 & 44.000 \\ \text { Kennemer-/Amstel- } & & & & \\ \text { en Meerlanden } & 22.000 & 18.000 & 30.000 & 35.000 \\ \text { Rijnstreek } & 30.000 & 23.000 & 34.000 & 35.000 \\ \text { Den Haag/Delft } & 37.000 & 27.000 & 33.000 & 42.000 \\ \text { Drechtsteden } & 15.000 & 13.000 & 18.000 & 18.000 \\ \text { Rijnmond } & 38.000 & 45.000 & 50.000 & 55.000 \\ \text { Zeeland } & 13.000 & 12.000 & 18.000 & 16.000 \\ \text { Westelijk Noord-Brabant } & 7.000 & 12.000 & 13.000 & 10.000 \\ \text { Breda en omstreken } & 16.000 & 18.000 & 19.000 & 15.000 \\ \text { Midden-Brabant } & 13.000 & 16.000 & 19.000 & 19.000 \\ \text { Noord-Oost Brabant } & 18.000 & 25.000 & 28.000 & 25.000 \\ \text { Zuid-Oost Brabant } & 21.000 & 27.000 & 34.000 & 30.000 \\ \text { Midden- en Noord-Limburg } 16.000 & 20.000 & 21.000 & 23.000 \\ \text { Zuid-Limburg } & 22.000 & 22.000 & 29.000 & 28.000 \\ & & & & \\ \text { Totaal } & 526.000 & 547.000 & 681.000 & 701.000 \\ & & & & \end{array}$

percentage

$\begin{array}{lr}\text { Groningen } & 9 \\ \text { Friesland } & 7 \\ \text { Drenthe } & 7 \\ \text { IJssel-Vecht } & 8 \\ \text { Twente } & 8 \\ \text { Midden-IJssel } & 6 \\ \text { Veluwe } & 8 \\ \text { Arnhem/Oost-Gelderland } & 7 \\ \text { Nijmegen/Rivierenland } & 7 \\ \text { Flevoland } & 10 \\ \text { Oost-Utrecht } & 9 \\ \text { Midden- en West-Utrecht } & 8 \\ \text { Gooi en Vechtstreek } & 8 \\ \text { Noord-Holland Noord } & 9\end{array}$

9
10
9
10
11
8
9
10
9
9
7
7
6
8

$\begin{array}{rl}10 & 10 \\ 12 & 10 \\ 11 & 11 \\ 11 & 10 \\ 12 & 10 \\ 12 & 11 \\ 11 & 12 \\ 12 & 13 \\ 11 & 10 \\ 9 & 12 \\ 9 & 12 \\ 9 & 10 \\ 8 & 10 \\ 12 & 12\end{array}$


$-60-$

Tabel A.7. Aantal werkenden en percentage van de totale werkgelegenheid per opleidingstype en RBAgebied 1990, vervolg

\begin{tabular}{ccccc}
\hline RBA-gebied & $\begin{array}{c}\text { MAVO en } \\
\text { onderbouw } \\
\text { HAVONWWO }\end{array}$ & $\begin{array}{c}\text { LBO } \\
\text { Technisch }\end{array}$ & $\begin{array}{c}\text { MBO } \\
\text { Technisch }\end{array}$ & $\begin{array}{c}\text { MBO } \\
\text { Economisch \& } \\
\text { Administratief }\end{array}$ \\
\hline
\end{tabular}

Amsterdam/Zaanstreek/

Waterland

$\begin{array}{llll}8 & 6 & 8 & 10\end{array}$

Kennemer-/Amstel-

en Meerlanden

8

Rijnstreek

8

Den Haag/Delft

927

Drechtsteden

98

Rijnmond

Zeeland

98

Westelijk Noord-Brabant

Breda en omstreken

$7 \quad 12$

Midden-Brabant

9

Noord-Oost Brabant

Zuid-Oost Brabant

8

7

Midden- en Noord-Limburg

8

Zuid-Limburg

8

9

611

710

13

7

11

8

11

$\begin{array}{rr}8 & 11\end{array}$

$\begin{array}{lll}9 & 10 & 11\end{array}$

$\begin{array}{lll}8 & 12 & 11\end{array}$

$\begin{array}{lll}82 & 13 & 10\end{array}$

11

9

10

10

10

11

10

$11 \quad 11$

$11 \quad 10$

$12 \quad 11$

$10 \quad 11$

Totaal

8

9

11

11

Bron: CBS/ROA 
Tabel A.8. Werkloosheidspercentage per opleidingstype en RBA-gebied april 1991 (bemiddelingsbestand zonder baan)

\begin{tabular}{|c|c|c|c|c|}
\hline RBA-gebied & $\begin{array}{l}\text { 10 en } \\
\text { bouw } \\
\text { /NWO }\end{array}$ & $\begin{array}{l}\text { LBO } \\
\text { Technisch }\end{array}$ & $\begin{array}{c}\text { MBO } \\
\text { Technisch }\end{array}$ & $\begin{array}{c}\text { MBO } \\
\text { Economisch \& } \\
\text { Administratief }\end{array}$ \\
\hline Groningen & 20 & 14 & 4 & 4 \\
\hline Friesland & 19 & 14 & 3 & 3 \\
\hline Drenthe & 10 & 6 & 2 & 1 \\
\hline IJssel-Vecht & 10 & 5 & 1 & 1 \\
\hline Twente & 15 & 8 & 2 & 3 \\
\hline Midden-IJssel & 13 & 6 & 2 & 1 \\
\hline Veluwe & 9 & 4 & 1 & 1 \\
\hline Arnhem/Oost-Gelderland & 15 & 6 & 2 & 1 \\
\hline Nijmegen/Rivierenland & 16 & 9 & 2 & 2 \\
\hline Flevoland & 14 & 7 & 1 & 1 \\
\hline Oost-Utrecht & 10 & 2 & 1 & 1 \\
\hline Midden- en West-Utrecht & 12 & 5 & 1 & 1 \\
\hline Gooi en Vechtstreek & 11 & 6 & 1 & 1 \\
\hline $\begin{array}{l}\text { Noord-Holland Noord } \\
\text { Amsterdam/Zaanstreek/ }\end{array}$ & 12 & 6 & 1 & 1 \\
\hline Waterland & 29 & 17 & 4 & 2 \\
\hline \multicolumn{5}{|l|}{ Kennemer-/Amstel- } \\
\hline en Meerlanden & 9 & 4 & 1 & 1 \\
\hline Rijnstreek & 7 & 4 & 1 & 1 \\
\hline Den Haag/Delft & 16 & 11 & 2 & 1 \\
\hline Drechtsteden & 19 & 5 & $\overline{2}$ & 1 \\
\hline Aijnmond & 19 & 10 & 2 & 1 \\
\hline Zeeland & 10 & 5 & 1 & 1 \\
\hline Westelijk Noord-Brabant & 10 & 5 & 1 & 1 \\
\hline Breda en omstreken & 9 & 4 & 1 & 1 \\
\hline Midden-Brabant & 15 & 7 & 2 & 2 \\
\hline Noord-Oost Brabant & 14 & 7 & 2 & 2 \\
\hline Zuid-Oost Brabant & 14 & 7 & 2 & 1 \\
\hline Midden- en Noord-Limburg & 11 & 7 & 1 & 1 \\
\hline Zuid-Limburg & 15 & 12 & 2 & 3 \\
\hline Totaal & 15 & 8 & 2 & 2 \\
\hline
\end{tabular}

Bron: Arbeidsvoorzieningsorganisatie/ROA 
Tabel A.9. Conjunctuurgevoeligheid per RBA-gebied

RBA-gebied
Conjunctuurindicator

1,64

1,67

1,68

1,67

1,84

1,66

1,67

1,71

1,73

1,48

1,64

1,55

1,61

1,61

1,56

1,64

1,56

1,49

1,75

1,64

1,70

1,83

1,74

1,83

1,75

1,98

1,77

1,80
Typering

gemiddeld

gemiddeld

gemiddeld

gemiddeld

relatief hoog

gemiddeld

gemiddeld

relatief hoog

relatief hoog

relatief laag

gemiddeld

relatief laag

gemiddeld

gemiddeld

relatief laag

gemiddeld

relatief laag

relatief laag

relatief hoog

gemiddeld

gemiddeld

relatief hoog

relatief hoog

relatief hoog

relatief hoog

relatief hoog

relatief hoog

relatief hoog

Bron: ROA 
Tabel A.10. Bedrijfssectorspreiding per opleidingstype en RBA-gebied 1990 (Gini-Hirschman indicator)

\begin{tabular}{|c|c|c|c|c|}
\hline RBA-gebied & $\begin{array}{l}\text { MAVO en } \\
\text { onderbouw } \\
\text { HAVO/VWO }\end{array}$ & $\begin{array}{c}\text { LBO } \\
\text { Technisch }\end{array}$ & $\begin{array}{c}\text { MBO } \\
\text { Technisch }\end{array}$ & $\begin{array}{c}\text { MBO } \\
\text { Economisch \& } \\
\text { Administratief }\end{array}$ \\
\hline Groningen & 0,94 & 0,95 & 0,94 & 0,92 \\
\hline Friesland & 0,93 & 0,94 & 0,92 & 0,93 \\
\hline Drenthe & 0,90 & 0,94 & 0,95 & 0,89 \\
\hline IJssel-Vecht & 0.94 & 0,92 & 0,95 & 0.89 \\
\hline Twente & 0.94 & 0,93 & 0.94 & 0,94 \\
\hline Midden-IJssel & 0,92 & 0,92 & 0.94 & 0,91 \\
\hline Veluwe & 0.94 & 0,91 & 0,93 & 0,93 \\
\hline Arnhern/Oost-Gelderland & 0.95 & 0,94 & 0,94 & 0,93 \\
\hline Nijmegen/Rivierenland & 0,95 & 0,91 & 0,92 & 0.90 \\
\hline Flevoland & 0,91 & 0,95 & 0,93 & 0,93 \\
\hline Oost-Utrecht & 0,91 & 0,94 & 0,92 & 0,89 \\
\hline Midden- en West-Utrecht & 0,91 & 0,94 & 0,94 & 0,91 \\
\hline Gooi en Vechtstreek & 0,92 & 0,91 & 0,92 & 0,89 \\
\hline $\begin{array}{l}\text { Noord-Holland Noord } \\
\text { Amsterdam/Zaanstreek/ }\end{array}$ & 0,93 & 0,93 & 0,93 & 0.93 \\
\hline Waterland & 0,94 & 0,94 & 0,94 & 0,92 \\
\hline Kennemer-/Amstel- & & & & \\
\hline en Meerlanden & 0,93 & 0,92 & 0.94 & 0,92 \\
\hline Rijnstreek & 0,90 & 0,94 & 0,93 & 0,92 \\
\hline Den Haag/Delft & 0,93 & 0,94 & 0,94 & 0,90 \\
\hline Drechtsteden & 0,92 & 0,91 & 0,94 & 0,93 \\
\hline Rijnmond & 0,92 & 0,95 & 0,94 & 0,93 \\
\hline Zeeland & 0,95 & 0,94 & 0,92 & 0,90 \\
\hline Westelijk Noord-Brabant & 0,92 & 0,92 & 0,95 & 0.90 \\
\hline Breda en omstreken & 0,92 & 0,90 & 0,96 & 0,87 \\
\hline Midden-Brabant & 0,92 & 0,93 & 0,95 & 0,90 \\
\hline Noord-Oost Brabant & 0.94 & 0,91 & 0,92 & 0,91 \\
\hline Zuid-Oost Brabant & 0,94 & 0,94 & 0,94 & 0,93 \\
\hline Midden- en Noord-Limburg & 0,96 & 0,93 & 0,95 & 0,93 \\
\hline Zuid-Limburg & 0,93 & 0.97 & 0,95 & 0.92 \\
\hline Totaal & 0,94 & 0,94 & 0,95 & 0,92 \\
\hline
\end{tabular}

Bron: ROA 


\title{
BIJLAGE B: MOGELIJK TE PRESENTEREN BEROEPSKLASSEN PER PROVINCIE
}

\author{
ROA-code Beroepsklasse
}

\section{Groningen}

0132 Docenten voortgezet en hoger onderwijs

2011

2012

3021

4211

6124

6125

6211

6221

8111

8211

8212

\section{Friesland}

0132

2011

2012

3021

3312

4211

6124

6125

6211

6221

8111

8211

8212

\section{Drenthe}

0132

2011

2012

3021

4211

6124

6125

6211

8211

8212

Overijssel
Uitvoerend agrarisch personeel, bosarbeiders

Zelfstandige agrariërs, boswachters

Directeuren, bedrijfsleiders leidinggevenden industrie

Conducteurs, chauffeurs e.a. transportmiddelenbestuurders

Boekhoudkundige, belasting-, loket- en bankemployees

Commercieel-administratieve employees

Winkel-, straat- en marktverkopers, demonstrateurs

Winkeliers e.a. detail- en groothandelaren

Koks, kelners e.a. keuken- en serveerpersoneel

Portiers, schoonmaak- e.a. lager dienstverlenend personeel

Kinder-, gezins-, bejaardenverzorgenden e.a. verzorgend personeel

Docenten voortgezet en hoger onderwijs

Uitvoerend agrarisch personeel, bosarbeiders

Zelfstandige agrariërs, boswachters

Directeuren, bedrijfsleiders leidinggevenden industrie

Houtbewerkers, timmerlieden

Conducteurs, chauffeurs e.a. transportmiddelenbestuurders

Boekhoudkundige, belasting-, loket- en bankemplovees

Commercieel-administratieve employees

Winkel-, straat- en marktverkopers, demonstrateurs

Winkeliers e.a. detail- en groothandelaren

Koks, kelners e.a. keuken- en serveerpersoneel

Portiers, schoonmaak- e.a. lager dienstverlenend personeel

Kinder-, gezins-, bejaardenverzorgenden e.a. verzorgend personeel

Docenten voortgezet en hoger onderwijs

Uitvoerend agrarisch personeel, bosarbeiders

Zelfstandige agrariërs, boswachters

Directeuren, bedrijfsleiders leidinggevenden industrie

Conducteurs, chauffeurs e.a. transportmiddelenbestuurders

Boekhoudkundige, belasting-, loket- en bankemployees

Commercieel-administratieve employees

Winkel-, straat- en marktverkopers, demonstrateurs

Portiers, schoonmaak- e.a. lager dienstverlenend personeel

Kinder-, gezins-, bejaardenverzorgenden e.a. verzorgend personeel

Leerkrachten basis- en speciaal onderwijs

Docenten voortgezet en hoger onderwijs

Uitvoerend agrarisch personeel, bosarbeiders 
2012 Zelfstandige agrariërs, boswachters

3021 Directeuren, bedrijfsleiders leidinggevenden industrie

3312 Houtbewerkers, timmerlieden

3411 Drukkers, boekbinders, fotolaboranten

3613 Lassers, constructiewerkers, edelmetaalsmeden

3614 Machinebank- en plaatwerkers, gereedschaps- en modelmakers

3615 Onderhoudsmonteurs, fietsen- en instrumentmakers

3721 Elektriciens, elektro- en telecom(onderhouds)monteurs

3911 Metselaars, tegelzetters, straatmakers, stukadoors

3915

4011

4211

5021

5022

6122

6124

6125

6211

Overige bouwvaklieden, (spoor)weg-en reinigingswerkers

8111

Laders, lossers, vul- en inpak(machine)bedienden

Conducteurs, chauffeurs e.a. transportmiddelenbestuurders

Gediplomeerde verpleegkundigen, verloskundigen

Leerling-verpleegkundigen, zieken- en kraamverzorgenden

Secretaressen, typisten

Boekhoudkundige, belasting-, loket- en bankemployees

Commercieel-administratieve employees

Winkel-, straat- en marktverkopers, demonstrateurs

Winkeliers e.a. detail- en groothandelaren

8211

In-/verkoopchefs, handels- en verzekeringsagenten, makelaars e.d.

8212

Koks, kelners e.a. keuken- en serveerpersoneel

Portiers, schoonmaak- e.a. lager dienstverlenend personeel

\section{Gelderland}

0131 Leerkrachten basis- en speciaal onderwijs

0132 Docenten voortgezet en hoger onderwijs

0133 Schoolhoofden e.a. onderwijskundige beroepen

2011 Uitvoerend agrarisch personeel, bosarbeiders

2012 Zelfstandige agrariërs, boswachters

Directeuren, bedrijfsleiders leidinggevenden industrie

Bètaonderzoekers, technische vakspecialisten

3111 Voedingsmiddelenbereiders

3312 Houtbewerkers, timmerlieden

Drukkers, boekbinders, fotolaboranten

3612

Machinale metaalbewerkers

3613

Lassers, constructiewerkers, edelmetaalsmeden

3614

Machinebank- en plaatwerkers, gereedschaps- en modelmakers

3615

Onderhoudsmonteurs, fietsen- en instrumentmakers

Auto-, motor-en bromfietsmonteurs

Elektriciens, elektro- en telecom(onderhouds)monteurs

Produktiepersoneel bouwmaterialen-, glas- en aardewerkindustrie

Metselaars, tegelzetters, straatmakers, stukadoors

Overige bouwvaklieden, (spooriweg-en reinigingswerkers 
6031

6122

6124

6125

6126

6131

6132

6211

6221

6222

7033

8111

8121

8211

8212

9121

9221

\section{Utrecht}

0131

0132

2011

2012

3021

3031

3312

3411

3721

4011

4211

5021

5022

5031

6031

6122

6124

6125

6126

6131

6132

6211

6221

6222

6332

8111

8121

8211

8212
Hogere leidinggevenden

Secretaressen, typisten

Boekhoudkundige, belasting-, loket- en bankemployees

Commercieel-administratieve employees

Telefonisten, balie-employees, enquêteurs e.d.

Systeemanalisten, -programmeurs en -beheerders

Accountants, economen e.a. economische specialisten

Winkel-, straat- en marktverkopers, demonstrateurs

Winkeliers e.a. detail- en groothandelaren

In-/verkoopchefs, handels- en verzekeringsagenten, makelaars e.d.

Maatschappelijk werkers, reclasseringsambtenaren

Koks, kelners e.a. keuken- en serveerpersoneel

Houders en leidinggevenden horeca- en recreatiebedrijven

Portiers, schoonmaak- e.a. lager dienstverlenend personeel

Kinder-, gezins-, bejaardenverzorgenden e.a. verzorgend personeel

Politie-, brandweer- en bewakingspersoneel

Beroepsmilitairen

Leerkrachten basis- en speciaal onderwijs

Docenten voortgezet en hoger onderwijs

Uitvoerend agrarisch personeel, bosarbeiders

Zelfstandige agrariërs, boswachters

Directeuren, bedrijfsleiders leidinggevenden industrie

Bètaonderzoekers, technische vakspecialisten

Houtbewerkers, timmerlieden

Drukkers, boekbinders, fotolaboranten

Elektriciens, elektro-en telecom(onderhouds)monteurs

Laders, lossers, vul- en inpak(machine)bedienden

Conducteurs, chauffeurs e.a. transportmiddelenbestuurders

Gediplomeerde verpleegkundigen, verloskundigen

Leerling-verpleegkundigen, zieken- en kraamverzorgenden

Fysio-, arbeids- e.a. bewegingstherapeuten

Hogere leidinggevenden

Secretaressen, typisten

Boekhoudkundige, belasting-, loket- en bankemployees

Commercieel-administratieve employees

Telefonisten, balie-employees, enquêteurs e.d.

Systeemanalisten, -programmeurs en -beheerders

Accountants, economen e.a. economische specialisten

Winkel-, straat- en marktverkopers, demonstrateurs

Winkeliers e.a. detail- en groothandelaren

In-/verkoopchefs, handels- en verzekeringsagenten, makelaars e.d.

Juristen

Koks, kelners e.a. keuken- en serveerpersoneel

Houders en leidinggevenden horeca- en recreatiebedrijven

Portiers, schoonmaak- e.a. lager dienstverlenend personeel

Kinder-, gezins-, bejaardenverzorgenden e.a. verzorgend personeel 
ROA-code Beroepsklasse

Noord-Halland

0131 Leerkrachten basis- en speciaal onderwijs

0132 Docenten voortgezet en hoger onderwijs

0133 Schoolhoofden e.a. onderwijskundige beroepen

1321 Fotografen, filmers, vormgevers, etaleurs

1331 Beeldende en uitvoerende kunstenaars

2011 Uitvoerend agrarisch personeel, bosarbeiders

2012 Zelfstandige agrariërs, boswachters

3012 Machinisten bouw en industrie

3021 Directeuren, bedrijfsleiders leidinggevenden industrie

3023 Technische tekenaars

3031

3111

3312

3411

3613

3614

3615

3621

3721

3911

3913

3914

3915

4011

4211

4321

5021

5022

5031

5033

6031

6111

6121

Betaonderzoekers, technische vakspecialisten

Voedingsmiddelenbereiders

Houtbewerkers, timmerlieden

Drukkers, boekbinders, fotolaboranten

Lassers, constructiewerkers, edelmetaalsmeden

Machinebank- en plaatwerkers, gereedschaps- en modelmakers

Onderhoudsmonteurs, fietsen- en instrumentmakers

Auto-, motor- en bromfietsmonteurs

Elektriciens, elektro- en telecom(onderhouds)monteurs

Metselaars, tegelzetters, straatmakers, stukadoors

Huis-, scheeps- en constructieschilders

Loodgieters, saritair-installateurs en -reparateurs

Overige bouwvaklieden, (spoor)weg-en reinigingswerkers

Laders, lossers, vul- en inpak(machine)bedienden

Conducteurs, chauffeurs e.a. transportmiddelenbestuurders

Vliegers, boordwerktuigkundigen, transportdienstleiders

Gediplomeerde verpleegkundigen, verloskundigen

Leerling-verpleegkundigen, zieken" en kraamverzorgenden

Fysio-, arbeids- e.a. bewegingstherapeuten

Geneeskundigen, medische adviseurs, apothekers

Hogere leidinggevenden

Postdistributiepersoneel

6122

Administratief leidinggevenden

6124

Secretaressen, typisten

6125

Boekhoudkundige, belasting-, loket- en bankemployees

6126

Commercieel-administratieve employees

6131

Telefonisten, balie-employees, enquêteurs e.d.

6132

Systeemanalisten, -programmeurs en -beheerders

6211

Accountants, economen e.a. economische specialisten

6221

Winkel-, straat- en marktverkopers, demonstrateurs

6222

Winkeliers e.a. detail- en groothandelaren

6332

In-/verkoopchefs, handels- en verzekeringsagenten, makelaars e.d.

7021

7033

Juristen

7034

Auteurs, journalisten, nieuwslezers, presentatoren

Maatschappelijk werkers, reclasseringsambtenaren

Sociale wetenschapsbeoefenaren

Koks, kelners e.a. keuken- en serveerpersoneel

8211

Houders en leidinggevenden horeca- en recreatiebedrijven

Portiers, schoonmaak- e.a. lager dienstverlenend personeel 
8212 Kinder-, gezins-, bejaardenverzorgenden e.a. verzorgend personeel

8221 Kappers, schoonheidsspecialisten

9121 Politie-, brandweer- en bewakingspersoneel

9221 Beroepsmilitairen

\section{Zuid-Holland}

$0131 \quad$ Leerkrachten basis- en speciaal onderwijs

0132 Docenten voortgezet en hoger onderwijs

0133 Schoolhoofden e.a. onderwijskundige beroepen

1321 Fotografen, filmers, vormgevers, etaleurs

1331 Beeldende en uitvoerende kunstenaars

2011 Uitvoerend agrarisch personeel, bosarbeiders

2012 Zelfstandige agrariërs, boswachters

3012 Machinisten bouw en industrie

3021

3023

Directeuren, bedrijfsleiders leidinggevenden industrie

Technische tekenaars

3024

3031

3111

Technische analisten, amanuenses

Bètaonderzoekers, technische vakspecialisten

Voedingsmiddelenbereiders

3213

3312

(Zelfstandige) bakkers e.a. (industrieel) bakkerijpersoneel

Kleding- e.a. textiel- en bontproduktenmakers

Houtbewerkers, timmerlieden

Drukkers, boekbinders, fotolaboranten

3612

Produktiepersoneel chemische industrie

3613

Machinale metaalbewerkers

Lassers, constructiewerkers, edelmetaalsmeden

Machinebank- en plaatwerkers, gereedschaps- en modelmakers

Onderhoudsmonteurs, fietsen-en instrumentmakers

Auto-, motor-en bromfietsmonteurs

Elektriciens, elektro- en telecom(onderhouds)monteurs

Hogere elektrotechnici

Metselaars, tegelzetters, straatmakers, stukadoors

Huis-, scheeps- en constructieschilders

Loodgieters, sanitair-installateurs en -reparateurs

Overige bouwvaklieden, (spoor)weg- en reinigingswerkers

Bouwkundige technici, opzichters, werkvoorbereiders

Architecten, geodeten e.a. hogere bouwkundigen

Dokters-, tandarts- en dierenartsassistenten 
6121 Administratief leidinggevenden

6122 Secretaressen, typisten

6123 Bibliotheekassistenten

6124 Boekhoudkundige, belasting-, loket- en bankemployees

6125

6126

6131

6132

Commercieel-administratieve employees

Telefonisten, balie-employees, enquêteurs e.d.

Systeemanalisten, -programmeurs en -beheerders

Accountants, economen e.a. economische specialisten

Winkel-, straat- en marktverkopers, demonstrateurs

Winkeliers e.a. detail- en groothandelaren

In-/verkoopchefs, handels- en verzekeringsagenten, makelaars e.d.

Leden en leidinggevenden openbaar bestuur, beleidsambtenaren

Juristen

Auteurs, journalisten, nieuwslezers, presentatoren

Bibliothecarissen, archivarissen, conservatoren

Personeels- en beroepenspecialisten, arbeidsbemiddelaars

Maatschappelijk werkers, reclasseringsambtenaren

Overige sociaal-culturele en commerciële vakspecialisten

Koks, kelners e.a. keuken- en serveerpersoneel

Houders en leidinggevenden horeca- en recreatiebedrijven

Portiers, schoonmaak- e.a. lager dienstverlenend personeel

Kinder-, gezins-, bejaardenverzorgenden e.a. verzorgend personeel

Kappers, schoonheidsspecialisten

Politie-, brandweer-en bewakingspersoneel

Beroepsmilitairen

Zeeland

2012 Zelfstandige agrariërs, boswachters

3021

6124

6125

6211

8111

Directeuren, bedrijfsleiders leidinggevenden industrie

8211

Boekhoudkundige, belasting-, loket- en bankemplovees

Commercieel-administratieve emplovees

Winkell-, straat- en marktverkopers, demonstrateurs

Koks, kelners e.a. keuken- en serveerpersoneel

Noord-Brabant

0131 Leerkrachten basis- en speciaal onderwijs

0132 Docenten voortgezet en hoger onderwijs

0133 Schoolhoofden e.a. onderwijskundige beroepen

1321 Fotografen, filmers, vormgevers, etaleurs

2011 Uitvoerend agrarisch personeel, bosarbeiders

2012 Zelfstandige agrariërs, boswachters

3012 Machinisten bouw en industrie

3021 Directeuren, bedrijfsleiders leidinggevenden industrie

3023 Technische tekenaars

3024 Technische analisten, amanuenses

3031 Betaonderzoekers, technische vakspecialisten

3111 Voedingsmiddelenbereiders

3212 Stoffeerders, schoen-e.a. lederwarenmakers 
Kleding- e.a. textiel- en bontproduktenmakers

Houtbewerkers, timmerlieden

Drukkers, boekbinders, fotolaboranten

Machinale metaalbewerkers

Lassers, constructiewerkers, edelmetaalsmeden

Machinebank- en plaatwerkers, gereedschaps- en modelmakers

Onderhoudsmonteurs, fietsen- en instrumentmakers

Auto-, motor- en bromfietsmonteurs

Samenstellers elektrotechnische produkten, kwaliteitscontroleurs

Elektriciens, elektro- en telecom(onderhouds)monteurs

Hogere elektrotechnici

Produktiepersoneel bouwmaterialen-, glas- en aardewerkindustrie

Metselaars, tegelzetters, straatmakers, stukadoors

3914

Huis-, scheeps- en constructieschilders

3915

Loodgieters, sanitair-installateurs en -reparateurs

4011

Overige bouwvaklieden, (spoor)weg- en reinigingswerkers

4211

Laders, lossers, vul- en inpak(machine)bedienden

5021

Conducteurs, chauffeurs e.a. transportmiddelenbestuurders

5022

Gediplomeerde verpleegkundigen, verloskundigen

5023

Leerling-verpleegkundigen, zieken- en kraamverzorgenden

5031

Dokters-, tandarts- en dierenartsassistenten

5033

6031

Fysio-, arbeids- e.a. bewegingstherapeuten

Geneeskundigen, medische adviseurs, apothekers

Hogere leidinggevenden

Postdistributiepersoneel

Administratief leidinggevenden

Secretaressen, typisten

Boekhoudkundige, belasting-, loket- en bankemployees

Commercieel-administratieve employees

Telefonisten, balie-employees, enquêteurs e.d.

Systeemanalisten, -programmeurs en -beheerders

Accountants, economen e.a. economische specialisten

Winkel-, straat- en marktverkopers, demonstrateurs

Winkeliers e.a. detail- en groothandelaren

In-/verkoopchefs, handels- en verzekeringsagenten, makelaars e.d.

Maatschappelijk werkers, reclasseringsambtenaren

Koks, kelners e.a. keuken- en serveerpersoneel

Houders en leidinggevenden horeca- en recreatiebedrijven

Portiers, schoonmaak- e.a. lager dienstverlenend personeel

Kinder-, gezins-, bejaardenverzorgenden e.a. verzorgend personeel

Kappers, schoonheidsspecialisten

9221

Politie-, brandweer- en bewakingspersoneel

Beroepsmilitairen

\section{Limburg}

Leerkrachten basis- en speciaal onderwijs 
3312 Houtbewerkers, timmerlieden

3411 Drukkers, boekbinders, fotolaboranten

3612 Machinale metaalbewerkers

3613 Lassers, constructiewerkers, edelmetaaismeden

3614 Machinebank- en plaatwerkers, gereedschaps-en modelmakers

3615 Onderhoudsmonteurs, fietsen- en instrumentmakers

3721 Elektriciens, elektro- en telecom(onderhouds)monteurs

3811 Produktiepersoneel bouwmaterialen-, glas-en aardewerkindustrie

3915 Overige bouwvaklieden, (spoor)weg- en reinigingswerkers

4011 Laders, lossers, vul- en inpak(machine)bedienden

4211 Conducteurs, chauffeurs e.a. transportmiddelenbestuurders

5021 Gediplomeerde verpleegkundigen, verloskundigen

5022 Leerling-verpleegkundigen, zieken- en kraamverzorgenden

6031 Hogere leidinggevenden

6111 Postdistributiepersoneel

6122 Secretaressen, typisten

6124 Boekhoudkundige, belasting-, loket- en bankemployees

6125 Commercieel-administratieve employees

6126 Telefonisten, balie-employees, enquêteurs e.d.

6211 Winkel-, straat- en marktverkopers, demonstrateurs

6221 Winkeliers e.a. detail- en groothandelaren

6222 In-/verkoopchefs, handels- en verzekeringsagenten, makelaars e.d.

8111

8121

8211

8212

Koks, kelners e.a. keuken- en serveerpersoneel

Houders en leidinggevenden horeca- en recreatiebedrijven

Portiers, schoonmaak-e.a. lager dienstverlenend personeel

\section{Flevoland}

2011 Uitvoerend agrarisch personeel, bosarbeiders

6211 Winkel., straat- en marktverkopers, demonstrateurs 
SOl-code

Opleidingstype

Groningen

$000,111,201$

Basisonderwijs

301

$331-339$

$381-389$

401

$421-429$

436-439

451,454

$453,461-464$

$481,484,486$

MAVO en onderbouw HAVO/NWO

LBO Technisch

LBO Verzorgend

Bovenbouw HAVO/VWO

MBO Agrarisch

MBO Technisch

MBO Verpleging \& Ziekenverzorging

MBO Economisch \& Administratief

MBO Verzorgend

Fries/and

$000,111,201$

301

321-329

$331-339$

361-369

381-389

401

421-429

436-439

451,454

$453,461-464$

$481,484,486$

Basisonderwijs

MAVO en onderbouw HAVO/NWO

LBO Agrarisch

LBO Technisch

LBO Economisch-Administratief

LBO Verzorgend

Bovenbouw HAVO/VWO

MBO Agrarisch

MBO Technisch

MBO Verpleging \& Ziekenverzorging

MBO Economisch \& Administratief

MBO Verzorgend

Drenthe

$000,111,201$

Basisonderwijs

301

MAVO en onderbouw HAVO/VWO

331-339

LBO Technisch

LBO Economisch-Administratief

LBO Verzorgend

381-389

Bovenbouw HAVO/VWO

401

421-429

MBO Agrarisch

436-439

MBO Technisch

451,454

MBO Verpleging \& Ziekenverzorging

$453,461-464$

MBO Economisch \& Administratief

$481,484,486$

MBO Verzorgend

Overijssel

$000,111,201$

301

321-329

$331-339$

361-369

Basisonderwijs

MAVO en onderbouw HAVO/VWO

LBO Agrarisch

LBO Technisch

LBO Economisch-Administratief 
SOl-code Opleidingstype

$\begin{array}{ll}381-389 & \text { LBO Verzorgend } \\ 401 & \text { Bovenbouw HAVONWO } \\ 421-429 & \text { MBO Agrarisch } \\ 436-439 & \text { MBO Technisch } \\ 451,454 & \text { MBO Verpleging \& Ziekenverzorging } \\ 453,461-464 & \text { MBO Economisch \& Administratief } \\ 481,484,486 & \text { MBO Verzorgend }\end{array}$

Gelderland

$\begin{array}{ll}000,111,201 & \text { Basisonderwijs } \\ 301 & \text { MAVO en onderbouw HAVO/NWO } \\ 321-329 & \text { LBO Agrarisch } \\ 331-339 & \text { LBO Technisch } \\ 361-369 & \text { LBO Economisch-Administratief } \\ 381-389 & \text { LBO Verzorgend } \\ 401 & \text { Bovenbouw HAVO/VWO } \\ 421-429 & \text { MBO Agrarisch } \\ 436-439 & \text { MBO Technisch } \\ 451,454 & \text { MBO Verpleging \& Ziekenverzorging } \\ 453,461-464 & \text { MBO Economisch \& Administratief } \\ 466 & \text { MBO Bestuurlijk } \\ 471 & \text { MBO Sociaal-Cultureel } \\ 481,484,486 & \text { MBO Verzorgend } \\ 483 & \text { MBO Horeca \& Kappers }\end{array}$

Utrecht

000, 111.201 Basisonderwijs

301

331.339

$361-369$

$381-389$

401

$421-429$

436-439

451,454

$453,461-464$

MAVO en onderbouw HAVOIVWO

LBO Technisch

LBO Economisch-Administratief

LBO Verzorgend

Bovenbouw HAVO/VWO

MBO Agrarisch

MBO Technisch

MBO Verpleging \& Ziekenverzorging

$481,484,486$

MBO Economisch \& Administratief

MBO Verzorgend

Noord-Holland

$000,111,201$

301

Basisonderwijs

MAVO en onderbouw HAVONWO

$321-329$

LBO Agrarisch

LBO Technisch

$331-339$

341-349

LBO Haven \& Vervoer

$361-369$

LBO Economisch-Administratief

$381-389$

LBO Verzorgend

401

Bovenbouw HAVO/NWO

421-429

MBO Agrarisch 
SOI-code Opleidingstype

$\begin{array}{ll}436-439 & \text { MBO Technisch } \\ 441-449 & \text { MBO Haven \& Vervoer } \\ 451,454 & \text { MBO Verpleging \& Ziekenverzorging } \\ 453,461-464 & \text { MBO Economisch \& Administratief } \\ 466 & \text { MBO Bestuurlijk } \\ 481,484,486 & \text { MBO Verzorgend } \\ 483 & \text { MBO Horeca \& Kappers }\end{array}$

Zuid-Holland

$000,111,201$

301

Basisonderwijs

MAVO en onderbouw HAVO/VWO

$321-329$

LBO Agrarisch

LBO Technisch

341-349

LBO Haven \& Vervoer

361-369

LBO Economisch-Administratief

381-389

LBO Verzorgend

401

$421-429$

Bovenbouw HAVO/VWO

436-439

MBO Agrarisch

MBO Technisch

441-449

452

MBO Haven \& Vervoer

MBO Medisch Labaratorium

451,454

MBO Verpleging \& Ziekenverzorging

$453,461-464$

466

471

$481,484,486$

MBO Economisch \& Administratief

MBO Bestuurlijk

MBO Sociaal-Cultureel

483

MBO Verzorgend

MBO Horeca \& Kappers

Zeeland

$000,111,201$

Basisonderwijs

MAVO en onderbouw HAVO/VWO

301

$331-339$

LBO Technisch

LBO Verzorgend

381-389

401

436-439

Bovenbouw HAVO/VWO

MBO Technisch

453, 461-464 MBO Economisch \& Administratief

Noord-Brabant

$000,111,201$

301

321-329

$331-339$

361-369

$381-389$

401

$421-429$

436-439

441-449

Basisonderwijs

MAVO en onderbouw HAVO/VWO

LBO Agrarisch

LBO Technisch

LBO Economisch-Administratief

LBO Verzorgend

Bovenbouw HAVO/NWO

MBO Agrarisch

MBO Technisch

MBO Haven \& Vervoer 
SOl-code Opleidingstype

451, $454 \quad M B O$ Verpleging \& Ziekenverzorging

453. 461-464 MBO Economisch \& Administratief

466 MBO Bestuurlijk

471 MBO Sociaal-Cultureel

481, 484, 486 MBO Verzorgend

483

MBO Horeca \& Kappers

Limburg

$\begin{array}{ll}000,111,201 & \text { Basisonderwijs } \\ 301 & \text { MAVO en onder }\end{array}$

321-329 LBO Agrarisch

331-339 LBO Technisch

361-369 LBO Economisch-Administratief

381-389 LBO Verzorgend

$401 \quad$ Bovenbouw HAVO/VWO

421-429 MBO Agrarisch

436-439 MBO Technisch

451, $454 \quad$ MBO Verpleging \& Ziekenverzorging

453, 461-464 MBO Economisch \& Administratief

$481,484,486$ MBO Verzorgend

Flevoland

000, 111, $201 \quad$ Basisonderwijs

301

MAVO en onderbouw HAVO/VWO

$331-339$

LBO Technisch

436-439 MBO Technisch

453, 461-464 MBO Economisch \& Administratief 